BIBLIOTECA VIRTUAL DE CIÊNCIAS HUMANAS

\title{
AgraRistas POLÍTICOS BRASILEIROS
}

\section{Raimundo Santos}




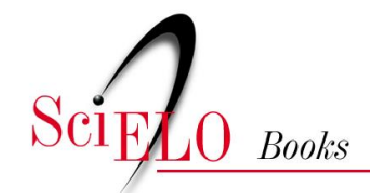

\title{
Agraristas políticos brasileiros políticos brasileiros
}

\author{
Raimundo Santos
}

SANTOS, R. Agraristas políticos brasileiros [online]. Rio de Janeiro: Centro Edelstein de Pesquisas Sociais, 2008. 153 p. ISBN: 978-85-99662-81-6. Available from SciELO Books <http://books.scielo.org $>$.

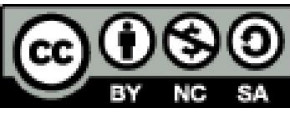

All the contents of this chapter, except where otherwise noted, is licensed under a Creative Commons Attribution-Non Commercial-ShareAlike 3.0 Unported.

Todo o conteúdo deste capítulo, exceto quando houver ressalva, é publicado sob a licença Creative Commons Atribuição Uso Não Comercial - Partilha nos Mesmos Termos 3.0 Não adaptada.

Todo el contenido de este capítulo, excepto donde se indique lo contrario, está bajo licencia de la licencia Creative Commons Reconocimento-NoComercial-CompartirIgual 3.0 Unported. 


\section{Raimundo Santos}

\section{Agraristas políticos brasileiros}

Rio de Janeiro
Esta publicação é parte da Biblioteca Virtual de Ciências Humanas do Centro Edelstein de Pesquisas Sociais - www.bvce.org

Copyright (c) 2008, Raimundo Santos

Copyright (c) 2008 desta edição on-line: Centro Edelstein de Pesquisas Sociais

Ano da última edição: 2007, Fundação Astrojildo Pereira/NEAD/IICA

Nenhuma parte desta publicação pode ser reproduzida ou transmitida por qualquer meio de comunicação para uso comercial sem a permissão escrita dos proprietários dos direitos autorais. A publicação ou partes dela podem ser reproduzidas para propósito não comercial na medida em que a origem da publicação, assim como seus autores, seja reconhecida.

ISBN 978-85-99662-81-6

Centro Edelstein de Pesquisas Sociais

www. centroedelstein.org.br

Rua Visconde de Pirajá, 330/1205

Ipanema - Rio de Janeiro - RJ

CEP: 22410-000. Brasil

Contato: bvce@centroedelstein.org.br 


\section{SUMÁRIO}

Nota de esclarecimento

\section{I - Parte Agraristas e Políticos Brasileiros}

Caio Prado Jr.: Valorização do Trabalho e Sindicalismo Rural ............1

O sentido da trajetória de Caio Prado Jr. ...................................................... 3

A valorização do trabalho na circunstância nacional ..................................... 8

O papel do sindicalismo na reforma do mundo rural ..................................... 13

O marxismo político de Caio Prado Jr. ............................................................. 20

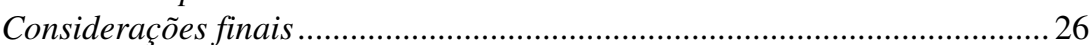

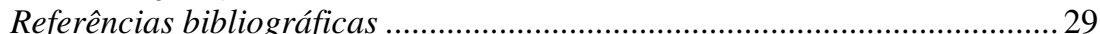

Alberto Passos Guimarães e a Revolução Agrária Não Camponesa....34

As possibilidades da revolução reformista ...................................................... 36

O tempo no socialismo brasileiro ..................................................................... 42

O papel dos sindicatos no "movimento camponês" .......................................... 49

Lênin e a revolução agrária não camponesa

Os fundamentos práticos da mediação política ................................................59

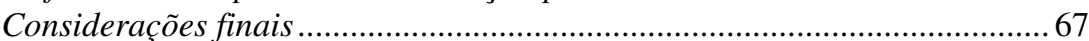

Referências bibliográficas .......................................................................... 71

Ivan Ribeiro: Via Prussiana, Democracia Política e Reforma Agrária .74

Um novo clima intelectual no campo pecebista ................................................. 76

Uma reforma agrária sob procedimentos democráticos ................................ 79

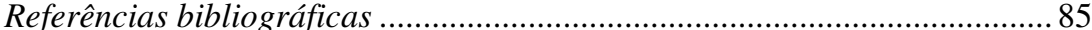

\section{II - Parte Textos Selecionados}

Caio Prado Jr.: O Estatuto do Trabalhador Rural .87

Alberto Passos Guimarães: As Três Frentes da Luta de Classes no Campo Brasileiro

A opressão imperialista no campo ............................................................... 99

A teoria e o método da luta de classes ........................................................... 100

As transformações burguesas e as forças motrizes....................................... 102

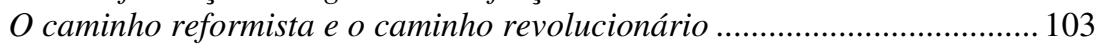

A frente dos assalariados e semiassalariados................................................ 109
A frente contra o latifúndio .......................................................................... 111

A frente de luta contra o imperialismo

Ivan Ribeiro: A Agricultura e o Capitalismo no Brasil .................... 116

1. Relações intersetoriais na economia brasileira ......................................... 118

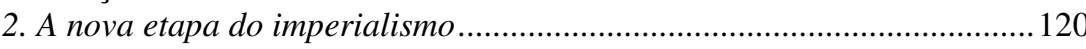

3. O modelo de transição ao capitalismo no Brasil .........................................122

4. Qual reforma agrária?............................................................................ 126

\section{III - Parte Apêndice}

Declaração sobre a Política do Partido Comunista Brasileiro ............. 129

I - O processo de desenvolvimento econômico do Brasil .............................129

II - A democratização da vida política nacional .......................................... 134

III - Crescem no mundo inteiro as forças da paz, da democracia e do

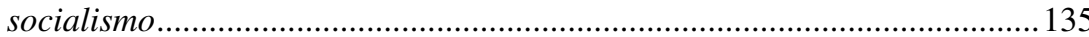

IV - Aprofunda-se a contradição entre a nação brasileira e o imperialismo

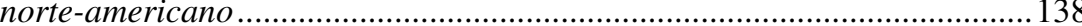

$V-A$ frente única e a luta por um governo nacionalista e democrático ........ 140

VI - O caminho pacífico da revolução brasileira ......................................... 147

VII - Pela vitória da frente única nacionalista e democrática nas eleições . 149

VIII - Fortalecer o Partido para a aplicação de uma nova política............. 152 


\section{NOTA DE ESCLARECIMENTO}

Os textos que integram a I Parte deste livro provêm da pesquisa "Perfis agraristas brasileiros" ora em andamento no CPDA (Programa de Pós-graduação em Desenvolvimento, Agricultura e Sociedade), da UFRRJ, e cujo objetivo consiste em comparar autores da vertente comunista com a matriz representada por José de Souza Martins, sociólogo que tem na reflexão de Florestan Fernandes sua referência básica.

Enquanto já dediquei vários textos a Caio Prado Jr., até agora só divulguei sobre Alberto Passos Guimarães e Ivan Ribeiro registros pequenos. Há muito tempo, saíram em Estudos Sociedade e Agricultura (junho de 1994) notas de minha autoria a propósito dos 30 anos de Quatro séculos do latifúndio. No final do ano passado, publiquei, naquela mesma revista, um curto artigo chamado "O agrarismo inconcluso de Ivan Ribeiro".

Correndo o risco de expor escritos com repetições e ainda carentes de mais investigação, resolvi compor este volume incluindo as duas partes do relatório da pesquisa acima citada, relativas a Passos Guimarães e a Ivan Ribeiro, assim apresentando um esboço da matriz em que se funda o agrarismo comunista no país. O livro cumpre parcialmente a intenção da pesquisa, mas ainda fica pendente uma publicação sobre as ideias de José de Souza Martins. Este autor, não seria exagero dizer, tem muita influência não só nos movimentos sociais (CPT-MST) do tempo mais recente, mas também em toda uma geração de estudiosos. A nosso ver, atentar para essa dimensão da obra do sociólogo da USP constitui um cometimento instigante na compreensão das mobilizações rurais dos dias de hoje.

Dei a este volume o nome de Agraristas políticos brasileiros, chamando a atenção para um aspecto importante no estudo dos três ensaístas aqui resenhados: são autores que formulam, para o campo de esquerda do seu respectivo tempo, argumentos muito além do registro da presença comunista no mundo rural. Neste sentido, espero deixar seus nomes associados a lineamentos da matriz comunista, com todas as aporias que ela carrega: a interpretação de Brasil (Caio Prado), a habilidade no agir político (Passos Guimarães) e a hipótese prussiana como cânone interpretativo-programático (Ivan Ribeiro). O volume traz uma II Parte com textos dos próprios ensaístas, selecionados entre os mais expressivos da publicística que cada um deles dedicou ao tema agrário e rural. O leitor encontrará no apêndice uma resolução pecebista que está presente em todos os ensaios da I PARTE: a Declaração sobre a política do PCB.

Agradeço os apoios recebidos do Núcleo de Estudos sobre Agricultura e Desenvolvimento (NEAD), da Fundação Astrojildo Pereira, de Brasília, do Instituto Interamericano de Cooperação para a Agricultura (IICA) e do CPDA, sem os quais a edição do presente livro não teria sido possível. 


\section{I - PARTE \\ AGRARISTAS E POLÍTICOS BRASILEIROS}

\section{Caio Prado Jr.:}

\section{VAlorizaÇão do TrabalHo E Sindicalismo RURAL}

Entendido como uma mobilização interativa com o meio sociocultural, o marxismo político que se construiu no Partido Comunista Brasileiro (PCB) teve certa gravitação entre nós, mesmo sem ter perfilado toda uma cultura política, como foi exemplar do Partido Comunista Italiano (PCI). O PC brasileiro conheceu uma via crucis de incompreensões que, no melhor dos casos, a bibliografia adversa apontou como falta de uma teoria sobre a circunstância brasileira.

De fato, com a distância do tempo, hoje se pode dizer que os comunistas não souberam aproveitar alguns diálogos que lhe foram oferecidos, como, desde logo, o diálogo com Gilberto Freyre (1933), sendo bem posteriores os momentos discursivos do $\mathrm{PCB}$, pelo menos os de maior relevância. É o caso da interpelação de Guerreiro Ramos nos tempos do centro-esquerda nacional-desenvolvimentista (Ramos, 1958; especialmente 1963). Com ressalvas aos temas caiopradianos da historiografia e da questão agrária, os críticos consideram o marxismo pecebista como uma ideologia meramente cosmopolita. Via de regra, o pecebismo daqueles anos alimenta-se de uma espécie de correição intramuros e da disputa pela posse da doutrina marxista-leninista com outros grupos militantes.

Mesmo sem ser propriamente uma interlocução, há uma segunda circunstância, tão constituinte quanto a narrativa freyriana, que precisa ser mencionada: o marxismo do "Seminário sobre Marx" realizado por alguns intelectuais da USP em 1958. Observe-se que o evento foi levado a cabo no mesmo ano da chamada Declaração sobre a política do PCB, texto com que o partido comunista, por assim dizer, se refunda na sequencia dos abalos que aqui chegaram em 1956, com as revelações sobre o stalinismo relatadas por Kruschev no XX Congresso do Partido Comunista da União Soviética
(PCUS). ${ }^{1}$ Não obstante esses estímulos, com sua mentalidade de autossuficiência patriótica ${ }^{2}$, o PCB não registra maior presença na esfera pública até os tempos bons e céleres da primeira Revista Civilização Brasileira de Ênio Silveira, no interregno 1966-68. Neste então tem curso um movimento que implicaria uma espécie de "ampliação" do marxismo brasileiro. Cria-se um clima intelectual no qual, mesmo sem os protagonistas planejarem os passos, disputavam-se os caminhos mais adequados à resistência à ditadura de 1964. Em uma verdadeira cena intelectual, abria-se à luz do dia um certo processo de arejamento do marxismo brasileiro. ${ }^{3}$

Ainda não investigamos como gostaríamos essas dimensões do marxismo brasileiro, quer as interpelações mais antigas (do pré-64), quer as mais contemporâneas. Em todo caso, em textos bem anteriores (Santos, 1993; 1996a e 1996b) havíamos apresentado Nelson Werneck Sodré e Caio Prado como as referências maiores do campo comunista. O primeiro, por valorizar os anos nacional-desenvolvimentistas e colocar-se a favor da tese da frente única democrática, que também julgava ser a via revolucionária adequada àqueles últimos tempos de vigência da Constituição de 1946; e o segundo, descrente na evolução espontânea do capitalismo, por mostrar reservas diante do que chamava de "aventura janguista". Vale dizer, a articulação de governo da qual participavam as "forças populares e progressistas", cujo "esquema" político, dizia Caio Prado às vésperas do golpe de 1964, não tinha bases para radicalizar o frágil processo como, à época, determinadas áreas suas vinham fazendo. No entanto, mais recentemente temos sugerido que se veja atentando-se aos textos de natureza publicística - uma outra disposição: Caio Prado e Alberto Passos Guimarães como passagens bem mais expressivas da tradição comunista no Brasil.

${ }^{1}$ Gilberto Freyre é citado em registro positivo por alguns autores comunistas (dois exemplos: Caio Prado Jr., em Formação do Brasil contemporâneo, 1942, e Alberto Passos Guimarães, em Quatro séculos de latifúndio, 1963). Acerca da controvérsia sobre stalinismo no PCB, da qual resultou a Declaração de Março de 1958, ver Santos, 1988. ${ }_{2}^{2}$ A noção "patriotismo de partido" aparece em Eric Mathias (1957; 1978).

${ }^{3}$ Ver a ensaística de Leandro Konder desse imediato pós-64, época da revolução teórica de Althusser (cf. Santos, 2002). Inscrita no debate sobre o novo marxismo científico, ela versa sobre a relação entre estruturalismo e política. Esse tipo de circulação de ideias traz à baila o papel da Revista Brasiliense (1955-54), como assinalaremos adiante, enfocando concentradamente o tema nacional 


\section{O sentido da trajetória de Caio Prado Jr.}

Logo advertimos que a presença desses autores no PCB não resulta apenas da inquietação interpelativa e afinidade em relação às posturas do partido comunista em determinadas conjunturas. Enquanto o historiador de São Paulo percorre grande parte da trajetória do PCB como seu alter ego, pelo menos desde 1947 - e não só por meio da teorização agrária -, Alberto Passos Guimarães emerge como autor influente na cena pecebista mais contemporânea. Como veremos, Caio Prado estará presente nos momentos congressuais pecebistas do largo pós-guerra. Terá influência mais visível sobretudo após os acontecimentos subsequentes ao suicídio de Getúlio, a partir de 1955, quando lidera o empreendimento da Revista Brasiliense até o desfecho de 1964. Sua obra teve ainda alguma gravitação nos breves anos entre 1966-1968.

Quanto a Alberto Passos Guimarães, sua contribuição mais marcante ocorre no cenário que se abre com os debates pecebistas sobre o Relatório Kruschev (1956-1957), já aludido. Em particular no V Congresso do PCB (1960), no qual o grupo dirigente que, em 1958, havia assumido o comando partidário com a Declaração de Março, consagra como orientação oficial as linhas gerais da "nova política" ali anunciada. Alberto Passos Guimarães aparece então como um publicista a lastrear a renovação comunista desse tempo. Era uma virada que vinha se gestando desde os primeiros anos 1950, quando o partido comunista começa a abandonar o campesinismo dos tempos mais duros da Guerra Fria e passa a reorientar a atuação agrária, área na qual mais se evidenciava o seu radicalismo.

Foi nesse tempo que os comunistas deram os primeiros passos rumo à tática de fundar sindicatos rurais com vistas a alcançar os camponeses, a "massa mais numerosa da nação", como diria a referida Declaração de Março, aludindo à conhecida expressão de $O$ dezoito brumário de Luís Bonaparte. Modesto, no entanto, o texto brasileiro de 1958 valoriza uma massa numerosa, cujo "movimento" era "bastante atrasado, sendo baixíssimo o seu nível de organização". ${ }^{4}$ Principal autor desse agrarismo

\footnotetext{
${ }^{4}$ Assim a Declaração de 1958 já delineava aquele caminho: a) "Para impulsionar o movimento camponês, é preciso partir do seu nível atual, tomando por base as reivindicações mais imediatas e viáveis, como o salário mínimo, a baixa de arrendamento, a garantia contra os despejos, e evitando, no trabalho prático, as palavras de ordem radicais que ainda não
}

novo, de tipo sindical-camponês, Passos Guimarães resistiria a duas pressões. De um lado, à ênfase caiopradiana posta nas relações de emprego de assalariamento dos "grandes domínios rurais"; terreno no qual, como veremos adiante, o historiador sugeria enraizar a tática comunista. De outro lado, e ao mesmo tempo, Alberto Passos Guimarães era combatido (e então acusado de "direitista") por áreas conservadoras do partido comunista por querer prosseguir com a "nova política" no V Congresso de 1960. Aliás, ele próprio teria exercido influência na resolução de 1958, a julgar pela semelhança entre algumas das proposições-chave desse texto e a argumentação apresentada pelo autor nos artigos que publica na Tribuna de debates daquele congresso.

Esse breve excurso vem nos mostrar como esses comunistas - um comentário extensivo a vários intelectuais - adquirem realce diverso quando lidos a partir da vocação militante dos seus escritos. No caso daqueles autores, a inscrição partidária e a destinação de seus textos ao campo pecebista não só os mostram como publicistas de partido, entre outros nomes, como sobremaneira nos revelam ser eles clássicos do marxismo político representado entre nós pelo PCB. Nas páginas seguintes faremos um exercício referido a Caio Prado, sublinhando a relação entre suas dissertações sobre a revolução e a política brasileira, no sentido da associação marxiana entre teoria e práxis (Marx e Engels, 1845; 1978).

Em primeiro lugar, impressiona a disciplinada militância do historiador, mesmo quando mostra independência intelectual (e política) em relação às teses do seu partido, dele discordando em momentos importantes. Mencione-se o desencontro por ocasião dos acontecimentos de novembro de 1935, quando, por ocasião dos levantes militares, vice-presidente da Aliança Nacional Libertadora (ANL), a mobilização de frente única que então se formava para intervir no pós-1930, Caio Prado viajava pelo Sul do país, onde seria preso e depois deslocado para São Paulo.

encontram condições maduras para a sua realização"; b) "Também no campo, a experiência demonstra que a atuação através de formas legais de luta e de organização é aquela que permite alcançar êxitos para as massas"; c) "Assim é que tem progredido, além das associações rurais e cooperativas, a organização dos assalariados e semiassalariados em sindicatos, que já obtiveram vitórias em contendas com fazendeiros"; e d) "Tem grande importância a defesa jurídica dos direitos já assegurados aos camponeses" (PCB, 1958; 1982: 188-89). 
Especialmente expressivo é o affaire dos chamados Comitês de Ação, encontros de oposicionistas que viabilizariam uma nova saída à superfície após as prisões de 1940, que dizimaram o PCB; subida à superfície da qual Caio Prado foi um dos principais articuladores. ${ }^{5}$

Recorde-se sua atuação na Assembleia Constituinte do Estado de São Paulo, em 1947, quando enfrenta a resistência da direção partidária a iniciativas reformistas que encaminha no exercício parlamentar (Prado Jr., 1960a).

Como mencionado, Caio Prado interpelou os três principais congressos comunistas: o IV Congresso, à época da primeira convocatória de 1947, para o qual escreveu "Os fundamentos econômicos da revolução brasileira" (o congresso só se reuniria em 1954); o V congresso de 1960, para cuja Tribuna de debates destinou o longo texto "As Teses e a revolução brasileira"; e, já sob ditadura militar, entre 1966-67, o VI congresso, quando publicou A revolução brasileira (1966), uma espécie de síntese da sua obra. Nesse opúsculo, o historiador justamente avalia o sentido geral da teoria pecebista; uma interpelação pública que gerou reclamações no PCB por ter Caio Prado recorrido na controvérsia a recurso desigual dada a clandestinidade em que viviam os comunistas.

Caio Prado manteve essa qualidade interpelativa bifronte - ao mesmo tempo em que se movia dentro do mundo comunista, sempre construiu vida publicística de superfície. Como também já aludido, passados os piores anos da Guerra Fria e da ilegalização do PCB, logo após o suicídio de Getúlio, o historiador emerge em 1955 à frente da Revista Brasiliense. ${ }^{6}$

5 Manuel Batista Cavalcanti relata que os Comitês de Ação foram uma iniciativa principalmente de comunistas de São Paulo e do Rio de Janeiro, para retornar à ação política de frente única em torno da União Democrática Nacional (UDN), em 1943 (Cavalcanti, 1983). Na bibliografia pecebista, os Comitês de Ação aparecem como um movimento "liquidacionista" ao modo do PC americano, que naquela época teve áreas suas postulando a substituição da forma-partido comunista por outro tipo de associação. Em vez daquela articulação pela redemocratização, a chamada Comissão Nacional de Organização Partidária (CNOP), que então organiza o PCB marginalizando o "grupo" de Caio Prado (Id.), tornou orientação do partido a aproximação com Getúlio, com o apoio de Prestes ainda na prisão. ${ }^{6}$ Elias Chaves Neto revela que o passo mais ambicioso do "grupo" caiopradiano após 1947 consistiu em convencer o historiador a participar do concurso da cadeira de Economia Política na Faculdade de Direito de São Paulo, para o qual ele escreveu "Novas diretrizes para uma política econômica brasileira" (1954). No texto, Caio Prado ensaia uma explicação da responsabilidade que o imperialismo teve no atraso e na miséria de amplas camadas da população brasileira. A finalidade da operação era usar o evento para romper com o
Durante quase todo o decênio seguinte, o empreendimento marcaria a opinião pública de esquerda, firmando a boa tradição de publicações de intelectuais comunistas e não comunistas que o próprio PCB já ensaiara antes no nosso curto pós-guerra democrático. Convocada por vários nomes do mundo cultural a ser "um centro de debates e de estudos brasileiros", a Revista Brasiliense se propunha não só difundir trabalhos sobre a circunstância nacional como também influir na opinião pública, "levando-a a melhor compreender os problemas que afetam a vida do país" (Revista Brasiliense, 1955). Definia-se, no abaixo-assinado da sua fundação, que a "revista, sem ligações de ordem política e partidária, será orientada pelos seus próprios redatores e colaboradores" (Id.).

Lembrando esse seu tipo de interpelação, qual o lugar do historiador no PCB e nas demais esquerdas? Não obstante a longa trilha que o converteria em um clássico da revolução, Caio Prado Jr. teve sua obra apropriada de maneira irregular. Ao mesmo tempo em que fundamentava $o$ agrarismo com o qual o PCB construía a rede sindical rural brasileira e também oferecia ao partido - sem muita acolhida explícita - uma concepção de reformismo, que o teria posto em condições mais competitivas naqueles anos ideológicos do nacional-desenvolvimentismo, o militante era empurrado para a margem do pecebismo oficial. ${ }^{7}$ Doutra parte, Caio Prado teve alguns textos - especialmente A revolução brasileira recolhidos por áreas (inclusive dissidências comunistas) que, depois de 1964 e às vésperas dos anos de chumbo, radicalizaram-se e viram no opúsculo amparo ao confronto armado com o regime militar, um confronto no qual iriam se envolver com alto custo.

simplismo puramente denuncista com o qual o PCB via o movimento nacionalista conferindo-lhe "um novo sentido" (Chaves Neto, 1977. p.142). Ao dinamizar o debate, a operação também amadureceu o projeto da Revista Brasiliense.

${ }^{7}$ Uma lista de artigos da imprensa partidária da época é bem expressiva: "Um falso conceito da revolução brasileira", assinado por Rui Facó em resposta aos comentários de Caio Prado às teses do IV Congresso ("Os fundamentos econômicos da revolução brasileira" (cf. A Classe Operária, Boletim de discussão n. 13, 1947); "É necessário combater e desmascarar os defensores e porta-vozes do nacional-reformismo", comentários de Luiz Carlos Prestes à Revista Brasiliense (cf. Voz Operária, 28/04/56); "A revolução brasileira", no qual Assis Tavares critica o livro de 1966 (cf. Revista Civilização Brasileira, n. 11-12, set. 1967); "O equívocos de Caio Prado Jr.”, folheto de Paulo Cavalcanti sobre o mesmo volume (São Paulo: Argumentos, s. d.) 
No entanto, as dissertações que o historiador produz não eram lidas como partes da interpretação de Brasil com a qual fundamentava sua teoria revolucionária. A dissertação sobre o Brasil-Colônia é o seu capítulo mais aceito; desenvolvida em Evolução política do Brasil (1933) e em Formação do Brasil contemporâneo (1942), não era vista como uma narrativa que conferia o sentido geral reestruturador do capitalismo que a revolução iria assumir no Brasil. Os excursos sobre a revolução burguesa (História econômica do Brasil, 1945) também encontravam dificuldade em serem reconhecidos pela bibliografia como partes do constructo de um ensaísta que se debruçou no estudo da nossa formação social com intenções revolucionárias. A esses excursos Caio Prado acrescenta instigantes, embora pouco desenvolvidas, alusões ao que chama de capitalismo burocrático e de Estado cartorial, na acepção de Hélio Jaguaribe, autor citado no "Adendo" à Revolução brasileira como "uma preciosa chave para a melhor compreensão e interpretação mais autêntica da realidade política brasileira" (Prado Jr., 1967: 238; 1978). ${ }^{8}$ Em certo sentido, essas alusões atualizavam sua imagem originária de Brasil.

São essas passagens dissertativas - e não a busca de exclusividade marxista, para fins ideológicos ou científicos, como se viu em certas áreas de esquerda nos anos 1960 e 1970 - que qualificam Caio Prado como ensaísta da nossa modernização de incorporação seletiva, de classes e vida associativa débeis e de cena política superficial, como ele costumava dizer. É num terreno nacional como este que teria curso a revolução brasileira, como a preferia chamar Caio Prado; uma ideia de revolução desenhada a partir das dissertações dedicadas: a) à nossa formação sob forma da colônia de produção; b) ao desenvolvimento agrário-burguês e ao nosso industrialismo; e c) ao renovamento do mundo rural, por ele entendido

8 A remissão a Jaguaribe mostra o historiador às voltas com a fórmula estrutura/superestrutura em contexto de estruturação não clássica do capitalismo. Por esta via, a dialética da interação forças produtivas/relações de produção opera refratada pela contemporaneidade de tradição e modernidade. Na interpretação da sua grande circunstância, "1945" mostra a importância que conferia à institucionalidade democrática. Após 1964, o autor voltou a criticar a teoria orientalista da revolução, segundo ele, de serventia para operações de risco e aventura. Como veremos, no ocaso do regime de 1964, a sua dissertação sobre o industrialismo torna-se um excurso sobre o capitalismo burocrático como um meio de retomar o tema do produtivismo, realçando a figura de uma burguesia tradicionalprodutiva, agora (em 1977) convergente, aliás, com a redemocratização do país desse tempo (Prado Jr., 1967 e 1977; 1978). como questão nacional. Neste sentido, pode-se falar da obra caiopradiana como busca de uma teoria revolucionária desde os primeiros escritos publicísticos (se já não nos artigos de 1935, bem visível em "Os fundamentos econômicos da revolução brasileira", de 1947, já citado) até $A$ revolução brasileira, seu "Adendo" de 1967 e o texto "Perspectivas em 1977”, da 6 edição.

\section{A valorização do trabalho na circunstância nacional}

Ao revelar desapreço pelo cânone (não só interpretativo) que orienta a interpretação do Brasil de Caio Prado, a própria bibliografia crítica sublinha a questão-chave: o circulacionismo do seu marxismo. ${ }^{9}$ Com efeito, em seu registro da Economia Política clássica - o segundo ensaio instigante sobre nossa "sociedade civil", logo depois de Gilberto Freyre ${ }^{10}$, Caio Prado vê que a singularidade brasileira não radicava no caldeamento racial propiciado pela colonização portuguesa, mas na circunstância de termos nascido como colônia de produção, na qual se conforma um povo com débil integração econômica, social e política. Aí estava, mutatis mutandis, a "esquematização" caiopradiana da nossa contemporaneidade. ${ }^{11}$ O historiador se coloca o problema da necessidade de um marxismo que desse conta do padrão civilizatório sob o qual se estruturara a nação. Não obstante a filiação ao marxismo clássico, em especial à teoria do capitalismo e suas categorias econômicas, o objeto da investigação de Caio Prado se concentra naquele padrão civilizatório, no mesmo estilo de ensaístas como Gilberto Freyre e Florestan Fernandes, cada qual, dito assim só para figurar a ideia, com sua "esquematização".

O comunista de São Paulo debruça-se sobre uma formação social que não se constitui - esta marca percorre sua obra - com base em um processo

\footnotetext{
${ }^{9}$ A passagem mais extensa encontra-se em Formação do Brasil contemporâneo, onde se lê: "A análise da estrutura comercial de um país revela sempre, melhor que a de qualquer um dos setores particulares da produção, o caráter de uma economia, sua natureza e organização. O estudo que vamos empreender do comércio colonial em princípios do século passado virá assim como coroamento e conclusão de tudo quanto se tratou acima" (Prado Jr., 1942: 226). ${ }^{10}$ A propósito desse sentido da obra de Gilberto Freyre, ver Moreira (1988). Para uma comparação entre os ensaístas, ver Santos, 2001; 2006a.

${ }^{11}$ Faz-se aqui uma alegoria em torno do conceito de raiz em Charles Taylor, segundo a versão que nos apresenta Jessé Souza em sua reinterpretação da modernidade periférica.
} Souza usa essa mesma conceituação para interpelar Florestan Fernandes (Souza, 2002). 
de criação, no próprio povo, do mercado para sua produção, primeiro mercantil, depois burguesa e moderna. Iria discernir que aqui, diferentemente do industrialismo europeu e americano, o mercado se torna a questão básica, enquanto a produção o fora para a economia política da industrialização clássica e para Marx. Essa circunstância merecia toda a atenção, como passo indispensável à tematização do desenvolvimento dos países que se haviam formado na periferia capitalista, como o Brasil, marcados por aquele traço primordial.

Caio Prado chega a calibrar o marxismo brasileiro - abrindo sua Economia Política ao tema do consumo (e da "população"), considerado assim em acepção, digamos, nacional-popular -, visando a explicar uma formação social ao mesmo tempo dependente (construída naquele sentido da colônia de produção) e contemporânea (industrializada de modo "superficial" e pouco incorporador). Dessa gênese e evolução ele extrai uma imagem do Brasil como sociedade de modernização tardia e incompleta, particularmente de classe econômica débil e campo popular pouco coeso; um tema, inclusive, já presente em Evolução política do Brasil (1933) e também descrito em Formação do Brasil contemporâneo (1942). ${ }^{12}$

No entanto, a bibliografia crítica daquele traço circulacionista não discernia que era ele que distanciava o marxismo de Caio Prado da própria matriz marxista-leninista. É esse marxismo que orienta as dissertações sobre o Brasil com as quais o historiador não só delineia um programa de reformas reestruturadoras do nosso capitalismo, como ainda, fiel à tradição leninista, enraíza a teoria revolucionária na economia, na luta de classes e no Estado, tomando-o, porém, como esfera de uma generalidade chamada a processar os "interesses da maioria da população"; e esta última noção se

\footnotetext{
${ }^{12}$ No primeiro livro, há alusões aos desdobramentos da Revolução da Independência, chegando Caio Prado a registrar a "atitude inconsequente" das classes subalternas após o nosso "1848". Menciona a grande massa escrava (50\% da população), de baixo nível intelectual e cultural, isolada principalmente nos "grandes domínios rurais" e cujo processo de constituição "em classe politicamente ponderável" só se daria "no decorrer do tempo". Refere-se ainda às camadas médias livres, grupo sem coesão social e tampouco sem "possibilidades de uma eficiente atuação política" (Prado Jr., 1933). Em Formação do Brasil contemporâneo, o autor faz referências aos contingentes de "desclassificados" e aos seres "sem bagagem cultural" e ainda próximos do mundo escravista (Prado Jr., 1942).
}

mostra intercambiável com a questão da nacionalidade, tal como a deriva daquele padrão civilizatório. ${ }^{13}$

Mas o publicista não se confunde com a demiurgia frequente no primeiro ensaísmo clássico. Mesmo sem formalizar completamente o constructo, o historiador procura divisar impulso mudancista em atores cujo potencial estava dado pela dinâmica da vida nacional, deitava raízes nos interesses econômico-sociais e semeava associativismo de tipo permanente. Ao recortar o campo do agir revolucionário na interseção das dimensões da economia, das classes e do poder, por conta da fraqueza da vida produtiva e da debilidade dos protagonistas, Caio Prado atribui relevo à opinião pública, a qual ganharia força à medida que se desenvolvessem os "grandes debates nacionais" e manifestaria sentido renovador, quando tais debates se polarizassem em razão dos "interesses da maioria da população". Esse constructo qualifica-o "ponto de vista do proletariado" que o historiador assume tanto na obra historiográfica como nos textos propriamente publicísticos. ${ }^{14}$

Vejamos como o autor, em outros textos, valoriza o "ponto de vista" do trabalho - e dos "interesses da maioria da população" - a partir da circunstância de uma revolução burguesa fraca. São referências em escritos expressivos de momentos nos quais o seu marxismo político torna-se mais visível e o historiador interpela o PCB, particularmente quando a teoria pecebista seria posta à prova pelos acontecimentos que levariam ao desfecho de 1964.

Antes, porém, um pequeno excurso sobre o tema da previsão do curso revolucionário e suas conjunturas, um excurso com o qual se pode aferir o sentido de dois livros revolucionários: o caiopradiano A revolução brasileira (1966) e A revolução burguesa no Brasil (1975), de Florestan Fernandes. Caio Prado vê a concretização da revolução em processos em que os atores são chamados a ter iniciativa. Por mais débeis e inorganizados que surgissem em sua descrição, Caio Prado reserva-lhes protagonismo público, suposto um sistema político aberto, mesmo no período

\footnotetext{
${ }^{13}$ Era de tal ordem a envergadura da reestruturação exigida para que alcançássemos o nível dos países que trilharam o primeiro industrialismo que Caio Prado dizia ser necessário, aqui, esforço similar ao dos primeiros planos quinquenais da URSS.

${ }^{14}$ A noção é tomada de Adolfo Sánchez Vásquez em sua crítica ao divórcio entre teoria e prática na obra de Althusser (Vázquez, 1978).
} 
autoritário, ${ }^{15}$ diferentemente de Florestan Fernandes em A revolução burguesa no Brasil, um texto que também se consagraria nas esquerdas, sobretudo intelectuais.

Recorde-se, apenas para sugerir um termo de comparação, que no capítulo 1 da primeira parte daquele ensaio (escrita em 1966, sob registro weberiano), Florestan faz alusões ao modelo da revolução passiva do Risorgimento italiano, que levara Gramsci a propor, como alternativa à via diruptiva de 1917, uma estratégia socialista de progressiva acumulação de forças, aliás, tal como sugerira Engels no seu testamento político (Engels, 1895; 1977). No entanto, ao redigir, em 1973, a terceira e última parte da monografia hoje clássica, o sociólogo da USP redimensiona o modelo interpretativo esboçado na primeira e na segunda seção. Como já foi dito, na sequiência do Ato 5, sob impacto do endurecimento do regime de 1964, Florestan vê cristalizar-se no processo brasileiro a tendência dos países latino-americanos à autocratização - noção com que Lênin qualificava o czarismo russo - como uma "lei de ferro" do capitalismo dependente. O sociólogo da USP daí extrai o dilema: "ditadura ou revolução", perdendo-se - proveitosa aquela conjectura a respeito do Risorgimento - uma alternativa analítica a esta disjuntiva catastrófica, à qual, de resto, também levava o marxismo estruturalista operante entre nós no imediato pós-64. ${ }^{16}$

Do qualquer modo, a propósito da previsão do curso revolucionário, chamam a atenção os artigos publicados na Revista Brasiliense, nos quais Caio Prado examina os tempos nacional-desenvolvimentistas até o golpe de 1964 sob o prisma das dissertações sobre o Brasil mais contemporâneo. Mirando além da conjuntura aparente, o historiador desqualifica a função dos "dispositivos partidários" à volta da figura de Vargas - PSD-PTB - que então dominavam a vida nacional, dissimulando um capitalismo de incorporação social limitada, baixa sociabilidade e avesso à institucionalização democrática. Em vez de divisar na cena pública um

\footnotetext{
${ }^{15} \mathrm{Em}$ A revolução brasileira, Caio Prado disserta programaticamente, como se o novo quadro comportasse a ação transformadora das classes e o regime de 1964 não fosse uma circunstância altamente restritiva (Prado Jr., 1966; 1967; 1978)

${ }^{16}$ Curiosamente, a pista indicada por Gramsci está numa espécie de "guerra de posições" que emergiria noutro ambiente como uma estratégia para deter o "processo de fascitização", que o regime militar experimenta justamente após 13 de dezembro de 1968, com o Ato 5 . Seria um partido marxista-leninista - o PCB - quem iria imprimir o "sentido gramsciano" da "guerra de posições" à resistência à ditadura daqueles anos de chumbo (PCB, 1970 e 1971).
}

terreno para iniciativas imediatistas, Caio Prado segue a "esquematização" com que construíra sua imagem de Brasil (fraqueza da revolução burguesa, debilidade das classes e da vida política) e releva vetores intervenientes no quadro nacional que haveriam de produzir resultados duradouros. ${ }^{17}$

Mal compreendida a cena do último tempo da Constituição de 1946 18 (e vista sem as marcas histórico-estruturais), o ator revolucionário tendia a não levar na devida conta que ela também já ensejara o populismo e alimentava a aventura "janguista", como dizia o historiador na Revista Brasiliense às vésperas de 1964, alertando para a falta de "bases políticas" da radicalização crescente naqueles anos turbulentos. Ao mesmo tempo em que refere tal circunstância ao padrão de modernização superficial, Caio Prado também reconhece debilidades no campo das "forças progressistas e

\footnotetext{
${ }^{17}$ Associe-se aos traços já referidos: a) a dimensão de generalidade do Estado, concretizável a partir de governos adminstrativo-políticos, como dizia o historiador, com rumo, sustentação na opinião pública e suporte influente dos partidos; b) os "debates nacionais", conferindo sentido mudancista ao curso político; e c) uma "polarização de forças" (aberta a oportunidade para um campo expressivo dos "interesses da maioria da população"). Na época, Caio Prado valorizou a eleição de Juscelino pelo fato de espelhar os ventos de mudança do pós-guerra com seu clima de reconstrução e desenvolvimentismo. Além disso, a nova administração ainda podia ser impulsionada pela opinião pública antigolpista dos tempos anteriores à eleição e posse de JK (Prado Jr., 1956a). Em relação ao papel dos partidos, ver Prado Jr., 1956b. No imediato pré-64, Caio Prado não vê o rumo dos acontecimentos como favorável ao processo revolucionário, especialmente a aproximação das "forças populares e progressistas" com Jango, para ele, uma aliança subordinada a interesses personalistas.

${ }^{18}$ A propósito desse tempo, Elias Chaves Neto provocou celeuma com seu artigo inaugural da Revista Brasiliense. A noção de União Nacional ali presente alude à conformação de uma força política capaz de sustentar uma "nova política econômica" que "proporcione(asse) à nossa indústria e à nossa agricultura os meios, não somente de suportar esses encargos elevação dos salários em face de carestia - mas de neles encontrar novas possibilidades de desenvolvimento" (Chaves Neto, 1955, p.29). Sua convocação das forças nacionais democráticas em torno da Constituição visava a assegurar condições preliminares para que tivesse livre curso um processamento das reivindicações populares de "modo construtivo"; em outras palavras, a luta econômica, "dentro dos direitos para esse fim estabelecidos em nossa Constituição - o direito de greve, de sindicalizarão, de reunião" -, é que torna possível o constante ajuste dos salários segundo as condições variáveis da produção" (Id.). Assim como na Revolução Francesa, que no século XIX trouxera enorme progresso ao mundo, aqui "a defesa da Constituição é, portanto, o ponto básico de uma política que visa, pela união de todos os brasileiros, a resolver os problemas dos quais depende a nossa prosperidade" (Id.). São afirmações que nascem na conjuntura da reconstitucionalização do país. Ver os comentários de Prestes no texto citado (Prestes, 1956).
} 
populares" e do associativismo popular, especialmente sindical, recusando, todavia, a propensão a messianismos, inclusive o de tipo revolucionário a que também induzia a tradição comunista. ${ }^{19}$

Caio Prado mantém sua visão sobre nossa "revolução burguesa de novo tipo" na periferia capitalista ao longo de pelo menos 30 anos (desde 1947, em "Os fundamentos econômicos da revolução brasileira") até 1977 (em A revolução brasileira, com o "Adendo" de 1967 e as "Perspectivas em 1977”). É notável ver como, alheio ao momento de ditadura (Coelho, 2000), no livro de 1966 retoma o sentido programático da narrativa sobre nosso capitalismo: sob evolução espontânea, a modernização (o industrialismo substitutivo) não alargaria "social e territorialmente" sua capacidade de incorporação, por si já muito seletiva. Daí o tema da integração percorrer todo o volume. Esta visão de uma grande reestruturação da vida nacional mediante processo revolucionário que revertesse o padrão estruturante da nacionalidade sob condições de uma revolução burguesa débil - traça uma linha de separação entre o historiador e a esquerda da época de A revolução brasileira, uma esquerda cujas áreas mais militantes estavam marcadas fortemente pela ideia de revolução disruptiva e socialista como poder popular e alteração radical do regime de propriedade. ${ }^{20}$

\section{O papel do sindicalismo na reforma do mundo rural}

Relembremos agora como o "ponto de vista do trabalho" orienta a dissertação agrária. À luz da interpretação de Brasil, ela pode ser vista como marco de um campo intelectual que não restringe a reforma do

\footnotetext{
${ }^{19}$ O livro de Paulo Iumatti sobre os diários caiopradianos de 1945 veio lançar luz sobre a presença de Caio Prado Jr. na segunda metade dos anos 1940. Há vários registros seus sobre o PCB, e dois deles merecem ser retidos: o "populismo revolucionário" e a subestimação das eleições. Mesmo que a sua recusa principal se volte para o populismo "pelo alto" do Estado Novo, Caio Prado Jr. também se refere ao populismo que medrava em torno da figura de Prestes em diferentes mobilizações do PCB daquela época (Iumatti, 1978).

${ }^{20}$ A Florestan não passaria desapercebido o sentido da "revolução brasileira" de que falava Caio Prado. Comentando, na época, o alcance revolucionário de $A$ revolução brasileira, o sociólogo da USP dizia do historiador: "Não descobri nele uma irrefutável substância socialista. Existe uma intenção socialista, sem dúvida, mas o programa proposto seria perfeitamente exequível por uma burguesia nacional bastante autônoma, inteligente e criadora para combinar, em bases puramente capitalistas, alguma sorte de welfare state com crescimento econômico acelerado" (Fernandes, 1968; 1980. p. 87).
}

mundo rural à questão fundiária. Caio Prado Jr. confere importância à ideia de uma reforma agrária não camponesa; um tema continuado sob registro diverso por outros autores no pré-64 e depois da destituição de Jango, inclusive em tempos bem recentes.

Na época da Declaração de Março de 1958, embora refratado, o agrarismo de Caio Prado fez-se presente no PCB, em particular, como já aludido no princípio deste ensaio, na fórmula da reforma agrária "inicialmente não camponesa", que se tornaria reforma agrária camponesa numa segunda fase. ${ }^{21}$ Por sua visão "não estagnacionista" pós-1958, o PCB adota, naqueles anos radicalizantes da "pré-revolução brasileira" (Furtado, 1962), a proposição programática das "medidas parciais de reforma agrária", bem ecléticas e nada catastróficas, nelas, aliás, refletindo-se o argumento não campesinista de Caio Prado. Fora desse campo, naquela época o conceito de reforma agrária ainda se amplia mediante o equacionamento propriamente nacional-desevolvimentista, como se pode ver em textos isebianos. ${ }^{22}$ Desperta particular interesse a modalidade de reforma agrária de Ignácio Rangel, autor que, avaliando a falta de condições políticas para um processo redistributivista, argumenta a favor de uma reforma agrária centrada em questões "não propriamente agrárias" (problemas estritamente agrícolas, como produção, preços, intermediação, etc.).

Em relação ao seu próprio campo, o historiador valoriza "a atenção especial com os assalariados e semiassalariados", elemento que, no pré-64, compunha a tática agrária sindical-camponesa dos comunistas. Mas, ao mesmo tempo, via na mistura errática de reivindicações trabalhistas e camponesas - que, segundo ele, aparecia no novo agrarismo do PCB - a

${ }^{21}$ No PCB, tal noção foi posta em circulação por Alberto Passos Guimarães, e o enunciado completo é este: "Enquanto, como está nas Teses, a reforma agrária não se transforma em bandeira dos próprios camponeses - diz o autor, concordando com o texto do V Congresso, que provavelmente influenciara -, é possível 'revolucionar' certas relações agrárias mediante uma reforma que não é, fundamentalmente, uma reforma agrária camponesa" [Este argumento provém de uma citação de Lênin]. E continua: "E, à medida que os camponeses forem levados a participar do movimento agrário, conduzidos pelo proletariado, em aliança com este, a reforma agrária ainda não camponesa se transformará numa reforma camponesa, o que acontecerá na segunda etapa da revolução anti-imperialista e antifeudal" (Passos Guimarães, 1960). Essa fórmula foi acolhida no V Congresso de 1960.

${ }^{22} \mathrm{O}$ autor isebiano serviria de referência a José Graziano da Silva ao colocar o tema da "reforma agrária não essencialmente agrícola" na ordem do dia aberta pelo chamado "novo mundo rural" dos últimos anos do século XX. Ver Silva, 1996; 1998 
primazia do tema da luta pela terra, o que levava a se perder a "réstia de bom senso" que os comunistas haviam adquirido quando passaram a dar atenção ao sindicalismo rural (Prado Jr., 1966).

O modelo caiopradiano da revolução "agrária e nacional" - na aparência, simples inversão da fórmula "anticolonialista e agrária antifeudal" prescrita pela III Internacional aos países coloniais e dependentes - sugere uma grande transformação ao modo americano, no sentido de que aqui também era possível buscar dinamismo em um Oeste (o largo mercado rural) complementar a um Leste (nossa industrialização) insuficientemente modernizado. ${ }^{23}$ Diversamente da tradição comunista, Caio Prado atribui essa função a um protagonismo popular não camponês assentado em reivindicações trabalhistas da força de trabalho dos grandes setores da agropecuária, mobilizada por sindicatos estáveis e espalhados pelos municípios brasileiros. Fazendo decorrer a ideia de revolução agrária da sua interpretação de Brasil, o clássico pensa na renovação do mundo rural como avivamento de um capitalismo débil que, entregue à própria lógica, ver-se-ia incapaz de modernizar o país e abrir espaço aos contingentes devastados, particularmente os excluídos do sistema produtivo agrário.

Ao contrário do vazio social que Gilberto Freyre debitava às nossas "revoluções políticas", ${ }^{24}$ Caio Prado referencia sua ideia de revolução agrária justamente na Abolição. É esta filiação que o historiador confere às vésperas de 1964, tempo de urgências e radicalismos - ao Estatuto do Trabalhador Rural (1963), comparando o alcance desta lei ao impacto generalizante que tivera o 13 de maio de 1888, ao conformar o contingente nacional da força de trabalho livre. No caso, como proteção de direitos, o Estatuto viria a universalizar processos socioeconômicos por meio da expansão de sindicatos nos grandes setores da agropecuária, onde estava -

\footnotetext{
${ }^{23}$ Elias Chaves Neto traz referências ao homestead da experiências americana (Chaves Neto, 1955). Chaves Neto relembra que foram justamente a distribuição de terras além do Mississipi, conforme o programa farmer de Lincoln, a contínua expansão territorial e a abertura de grandes mercados consumidores que serviram de base para o desenvolvimento industrial daquele país no século XIX (Id.). Seguindo Caio Prado Jr., Chaves Neto também via na "miséria e na fome da grande massa popular" a questão estratégica de cuja solução dependeriam as possibilidades do movimento de renovação da estrutura econômica da nação (Id.).

${ }^{24}$ Como se sabe, em alguns textos do pós-guerra, Freyre faz referências à trilha da revolução social abolicionista de Nabuco, ao mesmo tempo em que, em outros escritos, vê as revoluções positivista e "comunista" como revoluções unidimensionais por carecerem de alcance sociológico.
}

vale repetir o autor - o núcleo estratégico da revolução agrária, do qual se difundiriam à economia rural impulsos transformadores sustentáveis: os assalariados e semiassalariados, os "empregados agrícolas".

Em vez de um "movimento camponês" pela terra confinado em poucas regiões, Caio Prado aposta na mobilização desse campo popular, único capaz de assegurar trabalho revolucionário expansivo, "em profundidade", como ele dizia. Para além dos termos e paradigmas pecebistas, o historiador apresenta ao partido comunista uma teorização do rural derivada da sua hipótese sobre nossa gênese e evolução no sentido de um modernismo inconcluso. Como se observou no princípio destas notas, o autor propõe essa problematização nas categorias marxianas, mas, em vez de evocar um ser demiúrgico do processo modernizador, o "Capital", como se vê em outros constructos acadêmicos, era o trabalho mediado por uma extensa mobilização social - por meio da forma sindical moderna - que ocupava centralidade no tema da modernização e da reforma do mundo rural.

Em artigo sobre o Estatuto do Trabalhador Rural publicado na Revista Brasiliense (1963), o autor diz que não se sustentava uma transformação completa da estrutura e organização dos grandes setores da economia agrária sem um amplo "movimento social reivindicatório". Citemos o autor: "Seria naturalmente ingenuidade pura imaginar que um simples texto legal, estabelecendo a reorganização de nossas principais atividades agrárias e dando-lhes estrutura e funcionamento da produção completamente distintos e originais, tivesse a virtude, somente por si, e sem o amparo, impulso e instrumento de poderosas e ativas forças sociais, de determinar tais consequências. Ora não se apresenta nenhum sintoma ponderável da ação dessas forças. As reivindicações dos trabalhadores empregados na grande exploração rural brasileira vão noutro sentido que não o do fracionamento da base fundiária em que se assenta aquela grande exploração; e o da transformação deles, de empregados que são, em pequenos produtores individuais e autônomos. As reivindicações desses trabalhadores são as de 'empregados', que é a sua situação econômica e social. A saber, reivindicações por melhores condições de trabalho e emprego" (Prado Jr., 1963: 6-7). ${ }^{25}$

${ }^{25}$ Segue a passagem: "E de um tipo desses de reivindicações não é possível esperar que resulte uma ação voltada para a subdivisão e retalhamento da propriedade e destruição com isso da grande exploração. Se assim fosse, as reivindicações pendentes deveriam conter, em 
Esse grande "movimento social reivindicatório" poderia desequilibrar, a favor da força de trabalho, a lógica estruturante do mundo rural: a "contradição" entre os monopolizadores das condições de trabalho e os despossuídos rurais. Era essa, e não a contradição antifeudal e antilatifundiária, como pensavam os comunistas e outros grupos militantes, a "dialética econômica" que tensionava o mundo produtivo e rural brasileiro (Prado Jr., 1966). Assim, em vez da fórmula marxista-leninista, era tal desequilíbrio que estimulava os conflitos pela terra, os quais, por serem pontuais e esporádicos, não possuíam amplitude suficiente para sustentar a renovação do mundo rural ao "modo americano". Para Caio Prado, a luta pela terra, usando expressão bem mais contemporânea, não era a "questão política do campo" (Martins, 1982). O acesso à terra pressupunha forma associativa moderna e permanente; movimento esse que, afinal, se firmaria com a rede sindical inicialmente assentada por todo o país a partir da estruturação da União dos Lavradores e Trabalhadores da Agricultura do Brasil (Ultab), em 1954, e da Confederação dos Trabalhadores da Agricultura (Contag), em 1963, construções já mencionadas anteriormente.

Façamos agora um outro tipo de observação: a pequena presença de Caio Prado na controvérsia sobre o então chamado "objetivismo burguês". ${ }^{26}$ Em um dos textos publicados na referida Tribuna de debates, na qual também vê a tributação como meio para forçar o acesso à terra, Caio Prado diferencia o ponto de vista do trabalho do tributo proposto nas teses oficiais, o qual aparecia "mais como medida de incentivo à produtividade das grandes propriedades" (Prado Jr., 1960a; 1996: 69). ${ }^{27}$ Continuemos com o

gérmen, a solução das questões econômicas e de ordem técnica que se proporiam numa tal transformação do sistema produtivo. O que não é o caso".

${ }^{26}$ A expressão aparece no interior dos debates preparatórios do V Congresso de 1960, demarcando um grupo ortodoxo que reage à visão das Teses oficiais sobre o capitalismo brasileiro,já anunciada na Declaração de 1958 ("Nos quadros desta estrutura atrasada - dizia este documento sobre o estágio de desenvolvimento do país - foi-se processando um desenvolvimento capitalista nacional, que constitui o elemento progressista por excelência da economia brasileira" (PCB, 1958; 1982: 176).

$27 \mathrm{O}$ comentário se referia às "erradas premissas teóricas" da tese 41 , por não trazerem argumento dirigido à melhoria das condições de vida da população trabalhadora rural ("Isso constitui uma típica formulação burguesa do problema agrário. $\mathrm{O}$ incremento da produtividade será uma consequência da reforma agrária: disso não restam dúvidas”) (Prado Jr., 1960b; 1996: 69). autor: "Essa melhoria não será trazida pelo simples aumento da produtividade, como mostramos acima; e ocorrem mesmo frequentemente situações em que o aumento da produtividade agrícola é acompanhada pelo agravamento das condições de vida do trabalhador. A contradição fundamental na economia agrária brasileira reside, como vimos, na oposição de grandes proprietários e a massa trabalhadora efetiva ou potencialmente a serviço deles, seja qual for a forma das relações de trabalho vigente - salariato, semiassalariato, parceria ou formas mistas. É no terreno da luta social em que aquela oposição se manifesta, que a reforma agrária deve ser colocada. A par das reivindicações imediatas (legislação trabalhista, regulamentação da parceria em benefício do trabalhador, etc.), figurará a facilitação do acesso da massa trabalhadora à propriedade da terra, o que determinará condições mais favoráveis à luta dos trabalhadores. A tributação, como medida essencial para aquele fim de proporcionar terra aos trabalhadores, deve portanto visar, em primeiro e principal lugar, o barateamento e a mobilização comercial da terra, e não a simples produtividade, que será consequência da reforma e não constitui condicionamento dela" (Id.: 69-70).

Mediado por tal tipo de movimento social, em Caio Prado o tema do trabalho não é mobilizado de modo impreciso nem constitui simples evocação do princípio marxista-leninista da superioridade operária em relação aos seus aliados, mas advém de uma interpretação de Brasil. Aliás, a propósito da "questão política do campo", registre-se um ponto da bibliografia que está a merecer tratamento: por trás da busca da "questão política no campo" ou da "questão nevrálgica", como preferia o historiador, radicam, a rigor, imagens de Brasil diferenciadas por suas origens e significados singulares. Em uma comparação entre Caio Prado e José de Souza Martins, já se apontou o par exploração versus expropriação (Faria, 1990) como uma polaridade que distingue os autores em suas ênfases no trabalhismo e na terra, respectivamente.

Também se sugeriu que esse mesmo par não apenas diferencia sindicatos e ligas camponesas, negociação e confronto, pressão por políticas públicas e reivindicação de terra, como também, no fundo, configura dois estilos de mobilização agrária. Vistos de um ponto amplo, tais polaridades expressam linhagens de interpretação do Brasil, cujas construções explicitam - isso é importantíssimo - modos desiguais de conceber a conexão teoriaprática; ponto este sempre reivindicado pelos grandes nomes desses mesmos 
campos intelectuais, ${ }^{28}$ sobressaindo-se Caio Prado Jr. como outsider do primeiro deles. Vale dizer, um militante pouco valorizado pelo partido comunista como um dos clássicos do nosso ensaísmo e não assumido plenamente, mediante interpelações à sua teoria do Brasil e excursos sobre a revolução, proveitosos que teriam sido para o pecebismo contemporâneo.

Assim, à luz desse tipo de associação entre pensamento social e político, Caio Prado se nos afigura não apenas como pensador agrarista, mas também um dos publicistas constituintes do marxismo político brasileiro, como temos sugerido desde o princípio destas páginas. Ou seja, e dizendo de modo paradoxal, Caio Prado e Alberto Passos Guimarães (voltando ao outro autor comunista) respondem pelos registros mais expressivos dos êxitos de um partido que se esgotou com o fim da URSS. E falamos em êxitos, não obstante o partido comunista se exaurir na passagem aos anos 1990, após haver sido, em menos de um decênio, deslocado pelos novos grupos petistas, com a ajuda da Igreja, tanto do associativismo quanto do mundo intelectual. $\mathrm{E}$ isto mesmo que, neste mundo intelectual, os comunistas tenham produzido controvérsias sobre vários temas da chamada revolução brasileira, sempre expondo os seus argumentos, intramuros e na esfera pública, quer nas suas publicações quer em espaços da mídia nacional.

Com a distância do tempo e vendo as coisas a partir de hoje, podemos afirmar que a primeira e talvez a principal realização daquele partido comunista consiste em haver deixado na esquerda militante uma tradição de política democrática, anunciada em 1958 na sequiência dos debates sobre o stalinismo. São elementos de uma cultura política valiosa por sua origem difícil (forçando passagem em meio ao marxismo-leninismo e a posturas dogmáticas, algumas radicalizadas); uma cultura de esquerda também muito educativa, por causa da presença de não poucas ambiguidades, persistentes no PCB ao longo do tempo, mas não só nele, já que algumas ainda são visíveis hoje em outros grupos, inclusive do PT. Depois, mas não com menor importância, está o valor da contribuição dos comunistas para a melhora do mundo rural, tanto em termos da extensão de direitos (por meio do agrarismo sindical-camponês) quanto em relação ao que chamavam de "medidas parciais de reforma agrária", cuja proposição mais significativa - recordemse os tempos - teve início no imediato pré-64.

\footnotetext{
${ }^{28}$ Referimo-nos à matriz ora em tela - a conexão Caio Prado-PCB - e ao campo que tem Florestan como referência clássica e José de Souza Martins como principal autor agrarista.
}

Como igualmente já referimos, aquele tipo de sindicalismo prossegue em nossos dias na Contag, que ainda mantém certos traços antigos e faz lembrar a inspiração em Caio Prado. Por sua vez, foi por meio de um agrorreformismo de "soluções positivas" e gradualista, como aquele a que tende o PCB pelo menos desde meados dos anos 1950, que viria a se consolidar - digamos ao velho modo - um campesinato, ao qual Alberto Passos Guimarães, em seu tempo, se refere como um campesinato ainda por se constituir. Um campesinato que, ao fim do "século do comunismo", já se visualiza na figura da agricultura familiar, florescente aqui e em muitas partes do mundo desenvolvido. No entanto, como ainda veremos, Alberto Passos Guimarães e Caio Prado não são clássicos do marxismo político brasileiro apenas por trazerem até nós o registro intelectual da presença pecebista no nosso mundo rural.

\section{O marxismo político de Caio Prado Jr.}

Diferente do pecebismo inspirado na reflexão leniniana sobre a via prussiana no $\mathrm{PCB},{ }^{29}$ a contribuição caiopradiana percorre outro caminho. ${ }^{30}$ Conhecedor do primeiro ensaísmo (Alberto Torres e outros), de Casa grande \& senzala (1933) e, naturalmente, de Monteiro Lobato, o historiador tem como importante ponto de referência, como já anotamos, a comparação entre o padrão capitalista europeu e americano e nossa modalidade de constituição nacional. A distinção é recorrente, quer quando o autor tematiza as marcas da

${ }^{29}$ A ideia de via não clássica da revolução burguesa já está em Marx e Engels (Marx, 1852; 1977; Engels, 1895; 1977; 1891; 1973). Lênin sublinha do modelo original as duas formas de evolução do mundo rural - a prussiana conservadora (em andamento na Rússia da segunda metade do século XIX) e a via farmer. No caso russo, por ocasião da Revolução de 1905 , ainda estava aberta a porta à via americana, sendo possível a revolução assumir um curso burguês conduzido por uma coligação heterogênea de classes (campesinato, classe operária) (Lênin, 1905 e 1907). Voltaremos ao tema do uso dessa construção no PCB em um texto dedicado a Alberto Passos Guimarães. Por ora registremos que o recurso ao conceito leniniano abre uma trilha que, com o correr do tempo, afirma no PCB: a) a ideia da democratização política como sentido geral de uma revolução chamada a reverter o padrão autoritário da modernização e b) o valor do mundo da política como terreno da concretização contínua das mudanças sob Estado democrático de direito.

${ }^{30}$ Aqueles publicistas (antigos e novos) não advertiram que havia em Caio Prado outros suportes para o reformismo democrático. Para a questão acerca do lugar das formulações de Caio Prado no seu partido - comparadas suas referências intelectuais com as do pecebismo acima aludido -, ver um breve registro em Santos, 2006b. 
colônia de produção e do escravismo, quer quando disserta sobre a modernização e o industrialismo inconclusos mais contemporâneos.

Ao investigar o terreno nacional sob o prisma da conexão passadopresente, o historiador, como vimos, refaz axiomas da economia política sagrados na tradição marxista -, "adequando" a disciplina para assim equacionar o tema da dependência e chegar à meta que buscava: uma análise política habilitada a inferir o padrão das contradições e soluções de conflitos, daí relevando - a contrapelo do marxismo-leninismo -, o sentido institucionalizador (positivo) de processos sociopolíticos modernos (opinião pública, partidos, sindicalismo, etc.). Ao repetir em várias passagens da sua obra o contraponto entre a trilha dos países que se desenvolveram no capitalismo com democracia e institucionalidade robusta e o curso "defeituoso" da revolução burguesa no Brasil ${ }^{31}$, Caio Prado deixa indícios do seu compromisso com o emblema ocidental. Poder-se-ia dizer que, neste emblema, o autor divisa o programa-destino da nossa ida ao moderno, a despeito da sua longa filiação do socialismo real.

Essa adesão certamente comporta não pouca ambiguidade em um ensaísta que intui muito cedo que o socialismo - um "programa", escrevia em 1934, usando o termo em linguagem impressionista - nunca se realizaria como uma sociedade sem classes. ${ }^{32}$ É grande a tentação de ver nas passagens

31 Nelson Werneck Sodré, autor tão acusado de "linearidade" (para ele, 1930 era uma revolução antifundiária - cf. Sodré, 1963), tem uma nota na qual diz que a política de frente única da ANL, derrotada em 1935, fora um ponto alto da transição republicana que se iniciara em 1930, depois de o país ter passado pela "revolução burguesa sem o proletariado" (Sodré, 1962).

${ }^{32}$ Citem-se, de URSS. um novo mundo, algumas passagens. Em relação "à eventualidade de diferenciação de classes, peculiar ao novo regime", "entre a massa e uma minoria", o autor diz: "Nenhuma organização social (pelo menos as já de certa forma evoluídas e por isso mesmo complexas) pode dispensar uma direção. Nestas condições deverá surgir na própria sociedade que virá substituir a sociedade burguesa uma diferenciação entre o grupo investido desta direção e o resto da população. O socialismo portanto nunca passará de um programa: uma sociedade sem classes é impossível" (Prado Jr., 1934: 234). Caio Prado aduz um grande testemunho: "É um escritor alemão, Robert Mitchels, quem primeiro, creio, aventou este argumento". O historiador brasileiro lembra que Les Partis politiques fora escrito em 1911, sem o exemplo da Revolução Russa, e continua: "Ele [Mitchels] diz o seguinte: 'Ainda mesmo que as massas conseguissem arrancar o poder aos burgueses, não haveria aí senão uma aparência: surgirá sempre e necessariamente, no seio das massas, uma nova minoria organizada, que se elevaria á posição de uma classe dirigente. Eternamente em minoridade, a maioria dos homens se veria obrigada mesmo predestinada á triste fatalidade histórica de citadas um ponto de vista antiapriorístico - a marca posterior da interpelação ao PCB (Prado Jr., 1966) - em relação à doutrina que já se cristalizava à volta do novel socialismo, não obstante - repita-se - a aceitação sem reservas da URSS, que o historiador manteria em escritos bem posteriores (Prado Jr., 1960b e inclusive 1982). Fazendo alegoria com a introdução escrita por Leandro Konder para uma coletânea de textos luckasianos (Konder, 1980b), dir-se-ia que o compromisso de Caio Prado Jr. com o socialismo soviético o converte numa espécie de "Lukács" brasileiro.

Registremos, agora, que há em Caio Prado Jr. uma espécie de ampliação da teoria social marxiana, um movimento pouco desenvolvido que teria sido - se valorizado - benéfico ao discurso pecebista. Trata-se de pontos inseridos em uma doutrina fechada - assim chegava aqui o marxismo -, sendo o principal deles a referida ênfase na circulação, com a qual o autor "esquematiza" a questão da colônia de produção brasileira. Com efeito, Caio Prado Jr. vale-se do "Prefácio" à Contribuição à crítica da economia política (1859), fonte corrente ou quase única para publicistas que se veem limitados por vários motivos a trabalhar com a bibliografia clássica da tradição.

No caso do PCB, já foram apontados como causas dessa limitação o contexto de atraso cultural no qual os comunistas receberam o marxismo de versão soviética, ampliando sua "pobreza" teórica, bem como o isolamento intelectual a que foram obrigados pela clandestinidade intermitente. No entanto, o exemplo de Gramsci, ao produzir uma obra fur ewig confinado nas prisões mussolinianas, testemunha a possibilidade de superação dramática do constrangimento. De qualquer modo, tanto o historiador

suportar a dominação de uma pequena minoria saída do seu seio e de servir de pedestal á grandeza de uma oligarquia" (Id.: 235). E completa: "Este argumento é tanto mais interessante no momento atual que toda a ala dissidente da $3^{\text {a }}$ Internacional, chefiada por Trotski, descobre no regime soviético os germens desta diferenciação, a constituição de uma oligarquia dirigente: a burocracia" (Id.). "É certo que o perigo assinalado por Mitchels existe" - acrescia, recorrendo, desta vez, a Bukharin, segundo o qual aquela "degeneração" prosperava à medida que caíam as forças produtivas nacionais, e seria "paralizada" "com o seu crescimento e a supressão do monopólio da instrução dos quais resultaria - essa era a solução apontada pelo teórico russo para o "eterno problema de Mitchels" - "a produção em grande escala de técnicos e organizadores em geral" saídos da classe operária. O jovem externava sua fé no regime dos soviets, que, como ele mesmo dizia então, era de ampla abertura e podia vir a alargar as margens daquela "educação política e administrativa" (Id.: 236-7). 
brasileiro como o PCB, para não falar de ensaístas isebianos, com frequência usaram o "Prefácio" de $1859 .{ }^{33}$

Todavia, Caio Prado não recorre ao trecho marxiano destacado pelo teórico italiano nos Cadernos do cárcere, a saber, a passagem sobre a tempestividade das mudanças revolucionárias. ${ }^{34}$ É com aquela chave "topográfica" do "Prefácio" de 1859 - dialetizada pelo cânone circulacionista - que o historiador tece excursos de pensamento social sobre uma formação marcada pela cisão entre economia e população. Assim, ao caracterizar o processo da nossa estruturação, Caio Prado Jr. serve-se do modelo de Marx e Engels - traçado com grande abstração - sobre os largos ciclos históricos (Marx e Engels, 1847-1848; 1977). Os clássicos expunham a lógica que estrutura e governa toda e qualquer formação social fundada na determinação em última instância da economia e inteligível através da dialética entre o crescimento progressivo das forças produtivas e a transitoriedade das relações de produção. Tal lógica evidencia-se nos embates de classe e nos enfrentamentos sociopolíticos, requerendo níveis de análise mais concretos de sociedades historicamente determinadas, em particular nas circunstâncias de crise e mudança (a Revolução de 1848, a França até o golpe de Luís Bonaparte, etc.) (Marx e Engels, 1850-1851 e $1852 ; 1977)$.

No entanto, como sublinhamos, economia e população - termos com que Caio Prado Jr. procura decifrar a formação brasileira - aparecem em

\footnotetext{
${ }^{33}$ Além desta súmula marxiana, há na literatura isebiana referência à proposição leniniana do Que fazer?: "Sem teoria revolucionária, não há movimento revolucionário". É expressivo o lema de Álvaro Vieira Pinto: "Sem ideologia do desenvolvimento nacional, não há desenvolvimento nacional" (Pinto, 1960: 29).

${ }^{34}$ Eis o cânone usado por Gramsci: "Nenhuma formação social desaparece antes que se desenvolvam todas as forças produtivas que ela contém, e jamais aparecem relações de produção novas e mais altas antes de amadurecerem no seio da própria sociedade antiga as condições materiais para a sua existência. Por isso, a humanidade se propõe sempre apenas os objetivos que pode alcançar, pois, bem vistas as coisas, vemos sempre que esses objetivos só brotam quando já existem ou, pelo menos, estão em gestação às condições materiais para a sua realização" (Marx, 1859; 1977: 302). Já o trecho a que recorre Caio Prado antecede esta passagem: "Ao chegar a uma determinada fase de desenvolvimento, as forças produtivas materiais da sociedade se chocam com as relações de produção existentes, ou, o que não é senão a sua expressão jurídica, com as relações de propriedade dentro das quais se desenvolveram até ali. De formas de desenvolvimento das forças produtivas, estas relações se convertem em obstáculos a elas. E se abre, assim, uma época de revolução social" (Marx, 1859; 1977: 301)
}

ordem diversa da Economia Política clássica, como se pode ver, de modo bem explícito, em Diretrizes para uma política econômica brasileira (1954). Nesta monografia nada desimportante, na qual não por acaso a teoria revolucionária se nutre do seu tempo e de tema contemporâneo, o objeto é a política econômica, e o historiador interpela Keynes e Cepal ${ }^{35}$.

Em suma, com esse tipo de marxismo e com a inscrição no ensaísmo clássico, o labor do publicista consiste em refazer a ideia de revolução, recebida pelo PCB da III Internacional como uma luta nacional-libertadora à Oriente (Prado Jr., 1966). Ao longo dos seus textos problematiza a contemporaneidade brasileira como um processo duradouro de conclusão da nacionalidade e radica a revolução no renovamento da vida nacional com base na valorização do trabalho e também do próprio mundo produtivo; mundo econômico que, por sua vez, necessita se modernizar e se estender horizontal e socialmente no mesmo sentido do primeiro industrialismo clássico, conforme a trilha da Europa e Estados Unidos, países que, inclusive, haviam feito correções nos termos do Welfare State.

Com esse tipo de registro é possível acentuar dimensões menos aparentes do pensamento caiopradiano. O livro Formação do Brasil contemporâneo, por exemplo, pode ser relido não só a partir do "Prefácio" de 1859, como também de um recorrente raciocínio comparativo entre o caso brasileiro e a "colônia de povoamento" americana, de onde Caio Prado

\footnotetext{
${ }^{35}$ Citemo-lo: "Mas antes de considerar especificamente o caso brasileiro não será fora de propósito lembrar que a própria teoria econômica, no que tem hoje de mais autorizado e acatado, vem deslocando há muito tempo (quase vinte anos pelo menos) seu ponto de vista antes e tradicionalmente fixado de preferência no lado da produção do valor, para o do fim a que se destina, pelo menos em princípio essa produção, a saber, o consumo. Durante um século e mais, ou seja praticamente da aurora da Economia Política, tal como a entendemos hoje, a teoria econômica ortodoxa se construiu na presunção da famosa lei atribuída ao francês Jean-Baptiste Say (e por isso conhecida por lei de Say, mas na realidade devida a James Mill), segundo a qual "a produção cria o seu próprio mercado". As repetidas crises do sistema capitalista e finalmente a estagnação contemporânea às vezes interrompida por breves períodos de prosperidade (o inverso portanto do passado, quando a prosperidade era a regra e a depressão, o eventual e transitório), isso obrigou os economistas burgueses a confiarem menos na lei de Say e no presumido automatismo do ajustamento entre produção e consumo; e a voltarem suas atenções para o verdadeiro mecanismo desse ajustamento ou antes desajustamento, como a experiência tinha demonstrado. A chamada 'revolução keynesiana', hoje consagrada, não vem a ser em última instância senão uma explicação e tentativa de correção daquele desajustamento" (Prado Jr., 1954: 194-95).
} 
- recorde-se um dos primeiros pontos-chave do autor - extrai a conhecida proposição do sentido da colonização ${ }^{36}$.

Conhecedor dos primeiros ensaístas, e vindo logo em seguida a eles, Caio Prado tece rounder points sociológicos e de análise política (contemporâneo que era do Iseb, especialmente de Hélio Jaguaribe). Esses rounder points levam-no a fazer qualificações importantes na sua teoria revolucionária: a) sempre recorre à sua visão da industrialização brasileira, de "negócios fáceis", como um industrialismo incapaz de incorporar produtivamente os numerosos contingentes do "país de desocupados"; b) recusa os efeitos do "domínio britânico na Índia", que também aqui trariam consequências desastrosas à modernização do mundo rural; ${ }^{37} \mathrm{e} \mathrm{c}$ ) no tema da vida política, dirige a atenção para as marcas e sedimentações passivas que a colônia de produção teria imprimido nas mediações do mundo social e partidário, dissimulando, no personalismo e nas "agitações", a "superficialidade" do sistema político brasileiro contemporâneo.

\section{Considerações finais}

Esse tipo de releitura renova o interesse pelos textos publicísticos do autor. É o caso de ver como a proposição circulacionista (Prado Jr., 1942 e 1945) reaparece posteriormente. Relembremos como uma primeira referência o exemplo, no artigo de 1947, dedicado à "revolução burguesa de novo tipo", que Lênin pensara para um contexto capitalista periférico (qualificada a circunstância brasileira pela dependência).

No interior da fórmula leniniana, Caio Prado tece fios dissertativos diferenciadores: a) a estreita correlação entre a descrição do curso burguês, singularizado aqui pela ausência de robustas classes revolucionárias básicas nos modelos de Marx e de Lênin (burguesia e proletariado, para o primeiro, e camponeses, para o último) -, e o conceito de política econômica (lugar estatal supletivo da ação inovadora daquelas classes), referenciado o conceito pela valorização do trabalho; e b) a importância da grande empresa e seus "empregados agrícolas" e a revolução agrária centrada na lei trabalhista; ênfase vista não como formalização do papel do proletariado como condottiere dos camponeses, conforme prescrevia o marxismo-leninismo. Radicadas numa interpretação do Brasil, essas linhas dissertativas conformam a ideia caiopradiana de revolução como reorganização econômico-social e adensamento da vida nacional, aparecendo os constructos sobre a modernização menos completos do que a teorização agrária.

Todavia, há uma trilha a merecer melhor investigação: as referências externas à tradição comunista com as quais o historiador recusa a frente única do $\mathrm{PC}$, vale dizer, alguns axiomas próprios do primeiro ensaísmo clássico. Para ilustrar a questão, retomemos o emblema de análise política mais antigo: 1945, ou seja, a circunstância da segunda metade dos anos

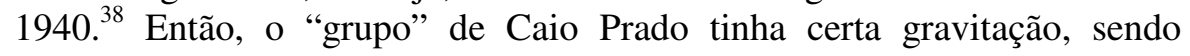

\footnotetext{
${ }^{38}$ Decorridos quinze anos da Revolução de 1930 (com engessamento da superestrutura, mas também expansão das forças produtivas), 1945 "encerrava tudo em si", registra Caio Prado Jr. nos seus diários (cf. Iumatti, 1998). E explica: “A política se agita, já agora sem reservas e publicamente. Arregimentam-se grupos, alianças e partidos... A luta começou, aberta e rasgada. Como terminará, por onde e para onde levará o Brasil?" (Ib.). O autor anota o aprendizado que as massas estavam tendo ao emergirem à vida pública numa situação dramatizada pela falta de "alicerces políticos" que permitissem superar tanto o alheamento da maioria em relação à vida cívica, quanto as agitações que marcavam a vida nacional. Se o
} 
notável a movimentação do publicista. Trata-se de uma conjuntura para cujo entendimento, no "grupo" caiopradiano, convergiam os seus constructos já esboçados. O desenho do emblema "1945" já exibe o marxismo refeito por exigência da tematização da colônia de produção. Este marxismo, depois, encerraria aos olhos dos críticos do historiador um paradoxo: quanto mais "economicista" a narrativa (vários autores indicam este ponto), tanto mais o marxista considera a política, campo do qual, aliás, provinha, por estar inscrito no PCB.

A rigor, Caio Prado é um publicista do pensamento social que mobiliza a noção de luta de classes na política segundo parâmetros que fincam sua análise no solo nacional: a) o da pobreza da população, ao modo do axioma do "país sem povo" com que Louis Couty alude à nossa conformação (Caio Prado traduz este tema para um contexto de capitalismo fraco); e b) o da falta de sólidos alicerces para a vida política nacional (recordar a contraposição entre Brasil real/legal, que reaparece em Caio Prado sob a chave da "dialética torta" entre sociedade e política, rounder point sobremaneira recorrente na sua ensaística) ${ }^{39}$.

novo daquele momento anunciava o fim da ditadura, o novíssimo era a "irrupção das massas" na vida pública, que só se consolidaria à medida que se criassem as instituições democrático-liberais. As oposições saíam à superfície, trabalhavam na organização da UDN e geravam "massa crítica" para a vida nacional, espalhando-a como "opinião pública" pela imprensa, pela política e pelos grupos partidários (Ib.).

39 Em 1945 Caio Prado Jr. já assinala as marcas das "agitações" e da "esterilidade" da vida política movida a partir de cima e defende a aliança do PCB com os liberais que se reuniam em torno da UDN. A amplitude desta aliança levaria ao fim da ditadura e a um caminho que daria curso às reivindicações populares, procurando-se assim afastar as massas do populismo e obter seu apoio duradouro. O historiador volta ao último tema no livro de 1966 como uma verdadeira "estratégia política" (Iumatti, 1998). No PCB iriam se contrapor a ideia de aliança com os liberais e o critério da avaliação da conjuntura da guerra defendido pela CNOP (cf. Cavalcanti, 1983). O novo núcleo dirigente muda o eixo da "política de união nacional", e o PCB se volta para as mobilizações "queremistas" da "Constituinte com Getúlio", daí decorrendo dois movimentos: a) a reorganização do PCB à margem do trabalho de unidade entre as esquerdas e o centro-esquerda, "desperdiçando-se", no dizer de Caio Prado, aquele momento de democratização (cf. Iumatti, 1998); e b) a substituição do que seria a esfera ideológica e intelectual dos Comitês de Ação. Por causa da falta de embasamento, segundo descrevem passagens dos diários caiopradianos, a nova orientação do partido de Prestes (assim passava a se chamar em certas áreas, cf. Cavalcanti, 1983) primava pela vagueza e o irrealismo das palavras de ordem e pela "improvisação" (sic) (Iumatti, 1978).
As dissertações sobre a revolução brasileira são coordenadas de uma arquitetura que singularizam a postura do historiador tanto na conjuntura crítica de 1945 como no movimentado pré-1964, expondo suas desavenças com o partido comunista. Por viver a um só tempo o comunismo e o ensaísmo, Caio Prado era de fato um outsider. Essa referência simultânea o distancia, por um lado, dos "prussianismos" - quer o propedêutico de Freyre (no sentido da ação reitora do Exército, chamado em momentos instáveis a vertebrar uma "sociedade civil" débil), quer o transicional de Jaguaribe (por meio de um Welfare State neobismarckiano à Partido do Congresso, de Nehru) (Freyre, 1950; 1965, e Jaguaribe, 1962). E, por outro, a boa "dupla militância" de Caio Prado diferencia-o das visões das esquerdas da época, seja a "sociologia" das contradições catastróficas (que alimentava grupos mais radicalizados), seja a variante pecebista do frentismo pluriclassista de inspiração nacional-popular, também recusada pelo historiador, sobretudo nas suas intervenções dirigidas aos V e VI Congressos, de 1960 e 1967. Tais intervenções, como já se frisou, só se entendem plenamente a partir do prisma da sua interpretação do Brasil.

Esta interpretação do Brasil - guardadas as distinções necessárias lembra Gilberto Freyre, o qual chegou a sugerir que sua obra representava uma alternativa ao que chamava de positivismo e ao comunismo políticos, carentes de lastro sociológico. No caso de Caio Prado, trata-se de uma interpretação marxista do Brasil comprometida com a busca da nossa especificidade, daí o verdadeiro teor dos seus desencontros com o seu partido. Aliás, com a distância do tempo, essa filiação merece ser evocada de um modo vívido e paradoxal. Dito de outro modo: se o PCB não adotou o seu teórico e o manteve à margem, faltou a Caio Prado o faro político dos comunistas brasileiros - uma falta da qual estes últimos ainda reclamavam na época de A revolução brasileira (1966).

Foi com a intuição que, após 1964, o PCB soube encontrar no que restava do mundo político destroçado pelos militares - e assaz desacreditado, como neste nosso tempo de governo das esquerdas militantes - o ponto de Arquimedes a partir do qual se faria a resistência democrática naqueles anos difíceis. E no entanto, lá atrás, em 1945, o historiador também lançara um olhar muito interessado na aliança das esquerdas com os liberais, convergência esta por muitos anos perdida. Em suma, nessa difícil convivência e por trás das tensões que os distanciavam, o historiador e o partido comunista mostraram - cada qual no seu elemento mais próprio, 
a criação intelectual e a ação política - o que mais sabiam fazer, sem, no entanto, se aproximarem suficientemente, como seria da natureza tanto de uma elaboração intelectual com vocação para o marxismo político quanto de uma ação política que necessitava fundamentar-se numa teoria do Brasil.

\section{Referências bibliográficas}

CHAVES NETO, Elias. Política de união nacional. Revista Brasiliense, n. 1, set./out. 1955. 1977.

Minha vida e as lutas de meu tempo. São Paulo: Alfa-Ômega,

BRESSER-PEREIRA, Luiz Carlos. Seis interpretações sobre o Brasil. Dados, v. 25, n. 3. Rio de Janeiro, 1982.

CAVALCANTI, Manuel Batista. Memórias (manuscrito). Campina Grande, 1983.

CAVAlCANTI, Paulo. Os equívocos de Caio Prado Jr. São Paulo: Argumentos, s/d.

COELHO, Marco Antonio. A herança de um sonho. Memórias de um comunista. Rio de Janeiro: Record, 2000.

ENGELS, F. Crítica al programa de Erfurt (1891). Madri: Anagrama, 1973.

. Introdução (1895) de As lutas de classes na França de 1848 a 1850. In: K. Marx e F. Engels. Obras escojidas. Moscou: Editorial Progreso, 1977, v. 1.

FACÓ, Rui. Um falso conceito da revolução brasileira. A Classe Operária, Boletim de discussão, n. 13. São Paulo, 1947.

FARIA, Sylvia Gomes. Contribuição à análise da luta pela terra no Brasil: as interpretações de Caio Prado Jr. e José de Souza Martins. Tese de Doutoramento, CPDA, Rio de Janeiro, 1990.

FERNANDES, Florestan. Caio Prado não disse tudo. Jornal da Senzala, n. 1, jan./fev. 1968. In: F. Fernandes. Em compasso de espera. São Paulo: Hucitec, 1980.
A revolução burguesa no Brasil. Rio de Janeiro: Zahar, 1975. FREYRE, Gilberto. Nação e Exército (1950). In: Seis conferências em busca de um leitor. Rio de Janeiro: José Olympio, 1965.

FURTADO, Celso. Reflexões sobre a pré-revolução brasileira. Revista Brasileira de Ciências Sociais, v. 2, n. 1, Belo Horizonte, 1962.

JAGUARIBE, Hélio. Desenvolvimento econômico e desenvolvimento político. Rio de Janeiro: Fundo de Cultura, 1962.

KONDER, Leandro. A democracia e os comunistas no Brasil. Rio de Janeiro: Graal, 1980a.

Lukács. Porto Alegre: LP\&m, 1980b.

LÊNIN, W. I. Dos tácticas de la socialdemocracia rusa (1905). In: Id. Obras escojidas en doze volumes. Moscou: Progreso, 1975, v. 1.

El programa agrário de la socialdemocracia rusa (1907). Moscou: Ediciones Lenguas Extranjeras, 1949.

IUMATTI, Paulo. Diários políticos de Caio Prado Jr. - 1945. São Paulo: Brasiliense, 1998.

MARX, C. e ENGELS, F. Teses sobre Feuerbach (1945). In: La ideologia alemana. Montevidéu: Ediciones Cultura Popular, 1978.

El manifiesto del partido comunista (1847-1848). In: Id. Obras escojidas. Moscou: Progreso, 1977, v. 1.

MARX, C. Las luchas de classes en Francia de 1848 a 1850 (1850-1851). In: Id. Obras Escojidas. Moscou: Editorial Progreso, 1977, v. 1.

El 18 brumário de Luis Bonaparte (1852). In: Id. Obras escojidas. Moscou: Editorial Progreso, 1977, v. 1.

O domínio britânico na Índia (1853). In: Id. Obras escolhidas. São Paulo, Alfa-Ômega, 1980, v. 1.

Futuros resultados do domínio britânico na Índia (1853) In: Id. Obras escolhidas. São Paulo, Alfa-Ômega, 1980, v. 1.

MATHIAS, Eric. Kautsky y el kautskismo (1957). In: C. Kautsky. La revolución social / El camino del poder. México: Cuadernos Pasado y Presente, 1978. 
MARTINS, José de Souza. Expropriação e violência. A questão política no campo. 2. ed. São Paulo: Hucitec, 1982.

MOREIRA, Adriano. Gilberto Freyre: o teórico da sociedade civil. In: M. do Carmo Tavares de Miranda (Org.). À memória de Gilberto Freyre. Recife: Massagana-Fundação Joaquim Nabuco, 1988.

PASSOS GUIMARÃES, Alberto. Uma falsificação e vários erros crassos na questão das etapas. Novos Rumos, Rio de Janeiro, 22-28 jul. e 28 jul-4 ago. 1960.

. Quatro séculos de latifúndio. São Paulo: Fulgor, 1963. PCB. Resolução sindical (1952). Problemas, São Paulo, dezembro de 1954.

. Declaração sobre a política do PCB (mar. 1958). In: Edgar Carone. $O P C B$. São Paulo: Difel, v. 2, 1982.

As Teses do V Congresso, folheto, Rio de Janeiro, 1960.

- Resolução política da comissão executiva do CE do PCB da Guanabara (folheto, mar. 1970). Temas de Ciências Humanas, n.10, São Paulo, 1981.

. Entendimentos políticos. Resolução do Comitê Central do PCB (folheto, set. 1971).

PINTO, Álvaro Vieira. Ideologia e desenvolvimento nacional. Rio de Janeiro: Iseb, 1960.

PRADO JR., Caio. Evolução política do Brasil. São Paulo: Revista dos Tribunais, 1933.

URSS, um novo mundo. São Paulo: Companhia Editora Nacional, 1934.

. Formação do Brasil contemporâneo. São Paulo: Brasiliense, 1942.

. História econômica do Brasil. São Paulo: Brasiliense, 1945.

Fundamentos econômicos da revolução brasileira. A Classe Operária, 1947.

. Diretrizes para uma política econômica brasileira. São Paulo: Brasiliense, 1954.
O sentido da anistia ampla. Revista Brasiliense, n. 4, São Paulo, mar./abr. 1956a.

A política brasileira. Revista Brasiliense, n. 8, São Paulo, nov./dez. 1956b.

As Teses e a revolução brasileira. Novos Rumos de 17 a 23/06/1960b. In: R. Santos (org.). Questão agrária e política: autores pecebistas. Seropédica, EDUR, 1996.

O mundo do socialismo. São Paulo: Brasiliense, 1960b.

O Estatuto do Trabalhador Rural. Revista Brasiliense, n.47, São Paulo, maio/jun. 1963.

. A revolução brasileira. São Paulo: Brasiliense, 1996.

Adendo de A revolução brasileira. Revista Civilização Brasileira, n.14, set. 1967; citado de A revolução brasileira. 6. ed. São Paulo: Brasiliense, 1978.

. Perspectivas em 1977. In: Id. A revolução brasileira, cit. 1982.

O que é a liberdade. São Paulo: Abril Cultural/Brasiliense,

PRESTES, Luiz Carlos. É necessário combater e desmascarar os defensores e porta-vozes do nacional-reformismo. Voz Operária, 28 abr. 1956.

RAMOS, Guerreiro. A redução sociológica. In: Id. Estudo da razão sociológica. Rio de Janeiro: Iseb, 1958.

O mito e a verdade da revolução brasileira. Rio de Janeiro: Zahar, 1963.

REVISTA BRASILIENSE. Abaixo Assinado. Revista Brasiliense, n. 1, São Paulo, ago. 1955.

SANTOS, Raimundo. O pecebismo inconcluso (1992). 2. ed. Revista e aumentada. Seropédica, 1996a

. Modernização e política. Rio de Janeiro: Forense Universitária, 1996b. 
Caio Prado Jr. na cultura política brasileira. Rio de Janeiro: Mauad, 2001.

. Um anunciador da questão comunista no Brasil. In: M. O. Pinassi (Org.). Leandro Konder. A revanche da dialética. São Paulo: Unesp-Boitempo, 2002.

Rurbanização e revolução agrária em dois registros clássicos (2001). In: Nora Fresno e H. Alimonda (Orgs.). Ruralidades, capacitação e desenvolvimento rural. Viçosa: Ed. UFV, $2006 a$.

O agrarismo inconcluso de Ivan Ribeiro. Estudos Sociedade e Agricultura, v. 14, n. 1, 2006b.

SILVA, José Graziano. Por uma reforma agrária não essencialmente agrícola (1996). In: Luiz Flávio de Carvalho e Raimundo Santos. Política e reforma agrária. Rio de Janeiro: Mauad, 1998.

SODRÉ, Nelson Werneck. Formação histórica do Brasil. São Paulo: Brasiliense, 1962.

Declínio do latifúndio. Tempo Brasileiro, n. 4 e 5, Rio de Janeiro, jun./set. 1963.

SOUZA, Jessé. A construção social da subcidadania. Para uma sociologia política da modernidade periférica. Belo Horizonte/Rio de Janeiro: UFMG/Iuperj, 2002.

TAVARES, Assis. (Marco Antonio Coelho). A revolução brasileira. Revista Civilização Brasileira, n. 11-12, Rio de Janeiro, set. 1967.

VÁZQUEZ, Adolfo Sánchez. Ciencia y revolución (el marxismo de Althusser). Madri: Alianza Editorial, 1978.

VIANNA, Luiz Werneck. Liberalismo e sindicato no Brasil. Rio de Janeiro: Paz e Terra, 1976.

Sobre a tática e a estratégia das Teses. Voz da Unidade, Debate n. 89, São Paulo, 1981.

\section{Alberto Passos Guimarães E A REVOLUÇÃo Agrária NÃo CAMPONESA ${ }^{40}$}

Quando se examina a publicística brasileira, observam-se várias referências ao nexo feudalidade-prussianismo com que Lênin caracterizou a formação social russa com fins revolucionários. Por muito tempo alguns autores pecebistas chamaram-nos a atenção por divisarem traços prussianos em nossa modernização, particularmente Nelson Werneck Sodré, no seu livro de 1962 e Ivan Ribeiro, autor que também recorre ao conceito leniniano ao se referir à agricultura do tempo mais contemporâneo (Ribeiro, 1975). Não centralizávamos no nexo leniniano o eixo do pensamento comunista que em meados dos anos 1950 começa a firmar seu compromisso com a democracia política (Santos, 1996). No entanto, já tínhamos registrado a presença da hipótese prussiana em outros intelectuais da geração de Ivan Ribeiro que, como este, buscam conferir alcance estratégico à política de resistência democrática ao regime de 1964. Eles tentam assentar esta valorização da democracia representativa em uma nova visão da nossa modernização (ver, por exemplo, Konder, 1980; Vianna, 1976, especialmente 1981). Quanto ao conceito de feudalismo, então observávamos que o seu uso tinha em Sodré e em Passos Guimarães um sentido instrumental. Em tal acepção - de "residualidade feudalista" contemporânea -, esta noção segundo a fórmula leniniana também adquire relevância no comunismo brasileiro. Neste texto sugerimos que o nexo feudalidade-prussianismo serve de ponto de referência a áreas comunistas que, nos tempos das inteligentsias imaginativas, como a do ISEB, começaram a indagar como seria o caminho brasileiro ao socialismo.

Só viemos a nos deter em Alberto Passos Guimarães como ensaísta dessa raiz quando melhor atentamos para o fato de que, no seu registro da questão dos "restos feudais", o autor de Quatro séculos de latifúndio (1963) igualmente menciona o outro termo da fórmula leniniana. Nesta ocasião mais recente, relíamos o ensaísta, indispostos com a bibliografia que o confina na pobreza teórica justamente por recorrer à hipótese feudalista. Este sumário juízo não permite averiguar se Passos Guimarães não se assemelha a outros

${ }^{40}$ Primeira parte do texto "Venturas e desventuras da revolução camponesa no Brasil" (Relatório parcial da pesquisa "Pensamento social e agrarismo no Brasil", CPDA/UFRRJ, outubro de 2007). 
autores cujas referências ao feudalismo não embotam suas imagens de Brasil, como Euclides da Cunha, Gilberto Freyre e Raimundo Faoro, por exemplo. Logo passamos a ver que a remissão àquele leninismo fazia de Passos Guimarães um publicista que não se restringia ao tema agrário. Favorecia este ponto os indícios que mostram ter ele influído na Declaração de Março de 1958; como se sabido, a resolução que encerrara no PCB a controvérsia sobre o stalinismo (1956-57) e fixa a "nova política", como é conhecida a virada na orientação dos comunistas dessa época.

Os autores que em diferentes momentos recorrem à hipótese prussiana não buscam apenas compreender o mundo agrário. Os publicistas do tempo da Declaração de Março, ainda sem suficiente clareza, defrontamse com consequências que lhes traz o uso do conceito. Por um lado, passam a ver outras dimensões na imagem de Brasil que possuíam e, por outro, a calibrar a estratégia do seu partido conforme a associação entre modernização conservadora e democracia política sugerida por aquele leninismo político. Eram, assim, levados a colocar seus fins de largo alcance a partir das ações do curto e médio termos, ou seja, pensar o agir revolucionário em função do reformismo democrático de frente única permanente, direção à qual os comunistas já vinham caminhando. Mesmo que o conjunto do partido não discernisse com muita precisão aonde iam os próprios passos e grande parte do seu núcleo dirigente negasse passagem a um aprofundamento do rumo renovador que tomaram.

Tendo esse pano de fundo, teceremos nestas páginas considerações sobre os seguintes pontos: a) sem partir de uma interpretação de Brasil que fundamentasse a revolução, dela, no entanto, Passos Guimarães esboça traços que o diferenciam de certas áreas pecebistas; b) sem chegar a uma teoria de revolução, o ensaísta pensa em uma "revolução nacional" por meio da luta de classes no mundo das mediações; no qual os protagonistas são convocados a incidir de modo efetivo; c) a publicística de Alberto Passos Guimarães se orienta para o domínio da conjuntura que então vivia o PCB; terreno no qual o ator é chamado a definir tarefas; e d) as especificidades da "revolução nacional" levam o autor a redimensionar o tipo de interpelação dos grupos agrários, lastreando aquela nova mediação à época já posta em prática pelos comunistas. $\mathrm{O}$ presente ensaio consiste numa recensão de alguns textos que Alberto Passos Guimarães dirige a seu partido, almejando o autor destas notas que, desde tal lugar militante, essa releitura do publicista avive traços do perfil do $\mathrm{PCB}$, inclusive das suas não poucas aporias, aliás, presentes ainda hoje em ambientes de outras esquerdas que se formaram bem depois daqueles tempos.

Concentramos a atenção nos artigos que Alberto Passos Guimarães escreve para os debates do V Congresso de 1960 e algumas vezes nos reportamos a Quatro séculos de latifúndio. Relevamos o congresso que reafirma a virada de 1958 e os textos nos quais o ensaísta busca delimitar para seu partido o campo do tempo real no qual os comunistas, segundo ele, haveriam de potenciar sua ação político-articulatória. Quanto ao seu excurso sobre a revolução agrária, sublinhamos o tema da interpelação camponesa a já nos referimos como de tipo sindical-camponês (Santos, 2002). Esperamos, ao final destas notas, deixar sugerido que com sua ideia de mediação Passos Guimarães antecipa pontos de um equacionamento do "problema camponês" que terá continuidade na matriz comunista. Referimo-nos aos ensaios com os quais Ivan Ribeiro retoma a questão agrária a partir dos temas da modernização conservadora da agricultura e da nova diversidade camponesa no pós-64. Agora numa versão, por assim dizer, mais secularizada ainda, os protagonistas da interpelação dos agrários sendo referidos mais decididamente tanto à política como tal quanto ao tempo permanente das "medidas parciais de reforma agrária", como se dizia à época, ou, como estamos dizendo de alguns anos para cá, das "políticas públicas" as mais variadas dirigidas à reforma do mundo rural.

\section{As possibilidades da revolução reformista}

A rigor, Alberto Passos Guimarães se vale da teoria leniniana da revolução na periferia capitalista e dela nos traz não apenas o velho tema da relação entre reforma e revolução. O autor leva-nos a revisitar questões e controvérsias de um distante mundo pecebista expressivas do estilo de pensar e agir da esquerda histórica. São traços relativos a certos tipos de requerimentos, a saber: a) descortinado o campo de ação, como já aludido, o ator revolucionário é chamado a operar de modo efetivo; e b) ao batalhar por "reformas estruturais", dele também se exige que mostre "soluções positivas"; e c) concretizadas algumas "soluções positivas", espera-se que ele valorize seus resultados (longe do "quanto pior, melhor"); postura que favorece tanto a continuidade das mudanças quanto pensar em eventuais ajustes na tática do curto prazo. 
À época da virada de 1958, Armênio Guedes foi um dos comunistas a registrar que a melhora no pensamento pecebista trazida pela Declaração de Março requeria projetar os objetivos mais próximos na questão geral da democratização do país. Nada consensual (muito menos naquele tempo), esta clássica controvérsia sobre reforma e revolução vem se apresentar sob a forma de uma discussão muito mal compreendida entre nós: a questão das etapas. No entanto, no PCB, a distinção entre a então chamada "etapa atual" da revolução brasileira e o futuro socialista torna-se questão definidora. Por aí passavam as possibilidades de um protagonismo que militasse a favor de uma revolução reformista no Brasil. Isto é, um protagonismo dependente da postura realista e lúcida do ator revolucionário ante a política realmente existente; ponto que à época repartia as esquerdas, em particular os comunistas, então também muito envolvidos na disputa pela posse da identidade doutrinária.

Diversamente da virada de 1958, parece não ter Alberto Passos Guimarães participado de forma importante na preparação das teses com as quais o Comitê Central do PCB convocou o V Congresso, embora seja um dos principais defensores da "nova política" na Tribuna de debates do evento. Nisso convergia com outros círculos pecebistas que então buscavam uma via política ao socialismo no Brasil (por exemplo, Chaves Neto, 1955, e Coelho, 1960), alguns publicistas aludindo ao caminho democrático ao socialismo de que falavam os comunistas italianos desde o XX Congresso do Partido Comunista da União Soviética (1956), tendo Palmiro Togriatti alguns textos seus publicados na imprensa pecebista dessa época.

No primeiro artigo dirigido ao V Congresso, "A questão das etapas da revolução brasileira", Alberto Passos Guimarães argumenta que a revolução de "libertação nacional" - num país como o Brasil - não se reduzia a este modelo oriundo do movimento comunista internacional. Ao se referir ao cenário prescrito pela III Internacional Comunista (IC) para os países coloniais e dependentes, Passos Guimarães faz uma primeira qualificação. Leva ao V Congresso a polêmica que Lênin sustentara contra os marxistas ortodoxos que insistiam na inevitabilidade de uma revolução burguesa na Rússia do início do século XX conduzida por um grupo econômico ao modo clássico. O líder bolchevique dizia que, desde meados do século XIX, a Rússia trilhava rota junker-conservadora. No entanto, ainda havia oportunidade para uma variante em moldes "democráticoburgueses", caso à frente dela se pusessem grupos sociais de outro tipo.
Esta abertura com que Lênin pensara o caso dos países que, como a Rússia, chegavam atrasados ao moderno arrastando um vasto mundo camponês, também era útil entre nós, qualificada a circunstância brasileira pela dependência. Com a mesma linguagem das Teses, Alberto Passos Guimarães fala de uma revolução igualmente em duas etapas - numa primeira, levada a cabo pela burguesia e noutra (fase de transformações propriamente anti-imperialistas e antifeudais) sob liderança do proletariado (Passos Guimarães, 1960a).

Ao invocar aquela proposição de Lênin $^{41}$, o autor visa singularizar uma "revolução nacional" já com certo desenvolvimento capitalista, o que nos diferenciava de outras nações coloniais e dependentes. Colocando o Brasil no modelo leniniano, também se podia pensar nossa modernização por caminhos não clássicos. De um tipo - retomava ele aquele leninismo - se a dirigisse grupos burgueses débeis coligados com velhos estratos pró-imperialistas e pré-capitalistas ou, de outro, caso se formasse uma aliança entre componentes burgueses interessados no desenvolvimento e agrupamentos reformistas influentes. Diz Passos Guimarães que no Brasil já chamava a atenção a presença de forças populares no movimento (burguês) de emancipação nacional que ganhara ímpeto nas cidades após o suicídio de Vargas (idem). Ao referir o modelo nacional libertador ao registro composto por Lênin para o capitalismo periférico, o ensaísta realçava traços especiais da revolução no Brasil, atento, como o PCB, à dinâmica daqueles animados anos nacionaldesenvolvimentistas e cepalinos.

Alberto Passos Guimarães repõe no V Congresso temas das próprias Teses oficiais sob registro que o diferencia em vários pontos. Assim, a questão das etapas não se subsumia a uma disputa doutrinária, sendo tema que conferia sentido aos movimentos do ator revolucionário. O publicista não

\footnotetext{
${ }^{41}$ O tema da "frente única" aparece na Declaração de Março como verdadeiro lema, a saber: "Nenhuma classe ou camada social, isoladamente, pode vencer as resistências das forças interessadas na conservação da dependência do país aos monopólios ianques e na manutenção do monopólio da terra. A experiência da vida política brasileira tem demonstrado que as vitórias anti-imperialistas e democráticas parciais só puderam ser obtidas pela atuação em frente única de várias forças interessadas na emancipação e no progresso do país. A aliança destas forças resulta, portanto, de uma exigência da própria situação objetiva" (PCB, 1960: 61). Num tópico chamado: "As classes sociais, o Estado e as instituições do Brasil", há sugestiva enumeração dos componentes da "sociedade civil" que comporiam a frente única.
} 
só busca desconstruir o radicalismo remanescente dos anos da Guerra Fria contra o qual viera a Declaração de Março -, como tenta divisar uma estratégia (a "arte" da política, como repete várias vezes, usando expressão de Lênin) que levasse os comunistas a incidir na conjuntura realmente existente naquela época. Tratava-se de dotar o agir no tempo presente de habilidades que favorecessem a diretriz das mudanças graduais e da formação dos (sucessivos) governos reformistas; terrenos estes - reformas e esfera estatal nos quais o ator operaria de modo construtivo com cálculo estratégico.

Como veremos adiante, o publicista também argumenta a favor do chamado caminho pacífico da revolução brasileira, uma das principais teses aprovada no V Congresso. Desde o suicídio de Getúlio, o PCB percebia que teria mais gravitação à medida que seguisse "normal" o curso dos acontecimentos sob o regime da Constituição de 1946. Por esse lado do problema, a questão agrária viria a adquirir outro significado no pensamento pecebista. Passos Guimarães aporta uma ideia de revolução agrária que atribuía ao "movimento camponês" papel diverso da função revolucionária stricto sensu definida no modelo da revolução democráticoburguesa. Este ponto do "papel dos camponeses na revolução" será controverso no V Congresso. Algumas áreas comunistas reagiram à minimização da importância dos agrários na frente única devido ao maior realce que, segundo diziam, tanto a Declaração de Março quanto as Teses conferiam à burguesia nacional. Alberto Passos Guimarães põe a questão em conformidade com a seguinte marca da circunstância nacional: o fato de termos entre nós um campesinato muito débil, como já anotara a Declaração de Março. ${ }^{42} \mathrm{Ou}$, dito de um modo mais geral: no Brasil, a revolução burguesa seria um processo sem a presença forte das classes que perfilavam os modelos revolucionários de Marx (a burguesia e proletariado) e de Lênin (um campesinato rebelde).

Logo voltaremos àquele primeiro artigo de Alberto Passos Guimarães e ao tema do curso "normal" dos acontecimentos. Vejamos agora o texto "Uma falsificação e vários erros crassos na questão das etapas", num ponto em que o autor responde aos seus críticos pelo modo "direitista" como trouxera ao congresso (diziam alguns deles na Tribuna de debates) a discussão sobre as etapas e deixemos o seu tópico agrário para mais adiante.

\footnotetext{
42 Recorde-se que o texto de 1958 dizia que o "movimento camponês" brasileiro era
} "bastante atrasado, sendo baixíssimo o seu nível de organização" (PCB, 1958; 1982).
Neste texto, o publicista centraliza sua polêmica na ambiguidade que havia sido introduzida nas "Teses". Ele a chama de "duas estratégias numa só etapa da revolução" e atenta para a indefinição que ela trazia ao ator ante sua circunstância mais próxima. Passos Guimarães se refere à dubiedade dessa questão da passagem do governo nacionalista e democrático (governo de frente única construído "nos quadros do regime vigente", hegemonizado pela burguesia e correspondente a toda uma etapa "histórica e estratégica") para o poder das forças anti-imperialistas e antifeudais "sob direção do proletariado" (Passos Guimarães, 1960b). Segundo o autor, as Teses haviam esboçado o problema das etapas "mas não o enfrentam(vam)" claramente. Diferenciadas aquelas etapas, as Teses, no entanto, tratavam dos objetivos e tarefas relativas a seus tipos de poder - aqui o ponto - como se se referissem a uma única fase. Essa era a aporia contida na referência das Teses à revolução brasileira como uma revolução "na atual etapa" (o tempo corrente e o futuro mais ou menos próximo) "anti-imperialista e antifeudal, nacional e democrática". Este complemento "nacional e democrática" diluía a função do governo nacionalista e democrático, repitase os termos daquela discussão, alcançado nos marcos do capitalismo.

O cotejo não era ocioso, quando se pensa que à época a "gramática" marxista-leninista marcava a ação militante. Passos Guimarães vê a revolução como um curso progressivo, inteligível justamente a partir da distinção cronológica. Reduzir as etapas a uma só constituía passo formulativo que levava o ator a desconhecer o mundo efetivo disposto à sua frente. Destituído de baliza, lançava-se a combate em chão incerto. "Sem estratégia", agiria sob influência de um futuro extraído de uma imaginária segunda etapa sob a ditadura proletária. O protagonista passava a guiar-se por uma problematização puramente abstrata da revolução. Daí a questão da etapa tornar-se decisiva: obrigava o PCB a enfrentar o "teste da revolução nacional" (sic). Aqui estava o calcanhar de Aquiles, o papel "turnessol", nas palavras de Passos Guimarães, que diferenciava os revolucionários ante o dilema que ameaçava "aprisionar" as Teses: ou aceitar a revolução nacional tout court, isto é, como uma revolução "que não vá além da emancipação burguesa da dominação imperialista (coisa à época, diz o autor, impossível sem o apoio do movimento democrático em que se inclui o proletariado)"; ou negar-lhe importância conquanto já não teria ela tempo para realizar transformações burguesas progressistas em moldes democráticos. 
O ponto consistia em conferir dimensão revolucionária ao que Alberto Passos Guimarães chamava de "período intermediário" e vislumbrar (em cores ainda doutrinais) o campo da luta política. O autor põe as esquerdas diante da questão mais geral do nosso capitalismo tardio: seguir rumo prussiano ou democrático conforme o tipo de atores à frente da modernização. Mas o argumento de Lênin também viria conferir sentido prático à "estratégia", ao agir no curto e médio prazos. A "etapa atual" da revolução, vale repetir, a hora a que o ator revolucionário é chamado a operar "e que é, queiram ou não os radicalistas da extrema ou da meia 'esquerda', uma etapa que corresponde a um período anterior ao da forma inicial da ditadura do proletariado, isto é, anterior à forma do poder das forças anti-imperialistas e antifeudais", diz o autor, usando linguagem marxista-leninista, mas se referindo a um futuro mais ou menos próximo (Passos Guimarães, 1960b).

Em "Uma falsificação e vários erros crassos na questão das etapas", Alberto Passos Guimarães exige que fosse esclarecida a questão do trânsito do governo nacional e democrático (no regime capitalista) ao governo do novo poder da etapa subsequente (idem) divisado na doutrina. O primeiro ponto seria registrar que o "governo nacional e democrático", de caráter burguês, desenvolver-se-ia abrindo caminho ao avanço da revolução brasileira em toda sua extensão até a fase anti-imperialista e antifeudal (idem). No caso dos articulistas com os quais polemizava no V Congresso ("esquerdistas", como os chama), essa questão de não se ter "estratégia" (diz o autor a propósito do que eles pensavam por trás daquela indefinição) aparecia no recurso que lançavam mão para se referirem à questão da etapa: o conceito clássico de etapa revolucionária. Isto é, tomavam-no no "sentido largo" de uma etapa marcada "por transformações qualitativas na base econômica (substituição de velhas relações de produção por outras novas) e na natureza de classe do poder político (substituição de classes no poder)" (idem). Passos Guimarães observa que tais articulistas recorriam ao mesmo conceito (como, aliás, lembra ainda, havia escrito o principal deles, Jacob Gorender, na Tribuna de debates do congresso) que usam os historiadores quando falam de grandes períodos. O desafio posto ao protagonista, no entanto, era divisar o teatro efetivo no qual se feria a luta na conjuntura precisa. Indo o ponto, diz Passos Guimarães: "Mas em política prática, o conceito para periodizar de antemão, para determinar a previsão estratégica, para delimitar as etapas históricas ou estratégicas, é o conceito stricto sensu de mudança na superestrutura, de mudanças nas instituições políticas, na composição de classe do poder, mudanças que são a condição política preliminar para as ulteriores transformações na base econômica, nas relações de produção" (idem). Não haveria, assim, porque a periodização dos acontecimentos e a delimitação das etapas ser tarefa exclusiva dos historiadores conquanto, neste caso, "que papel estaria reservado à estratégia política? quê seria da definição leninista da política como 'arte?", (idem), repete Passos Guimarães, citando seu autor preferido e precisando o ponto da incidência do ator no tempo presente e real.

\section{O tempo no socialismo brasileiro}

Desde o primeiro artigo, o sentido do argumento de Alberto Passos Guimarães consistia em afirmar no V Congresso, contra os "esquerdistas" (em meio "ao seu torneio de doutrinarismo"), a função da "estratégia política", a necessidade de o protagonista dispor de rota firme e segura. O autor reclama da ambiguidade quanto à "revolução nacional" (vê-la como revolução consumada ou negar-lhe valor) e lembra que os avanços da Declaração de Março e das Teses (na "interpretação dos fenômenos peculiares ao nosso país") haviam levado o PCB a um "problema novo" ainda obscuro na "nova política", qual seja, o de delimitar a "ordem de grandeza e a ordem de sucessão, no espaço e no tempo, das tarefas correspondentes à revolução brasileira, isto é, da revolução anti-imperialista e antifeudal" (Passos Guimarães, 1960a). Em vez de banalizá-lo, mesmo usando linguagem antiga, Alberto Passos Guimarães vê nesse tema "o mais complexo e o mais importante dos problemas a enfrentar para se trilhar o caminho brasileiro ao socialismo" (idem). O autor queria afastar a propensão à duplicidade de estratégias - compulsão, aliás, de grande aderência na cultura revolucionária -; ambiguidade que, repita-se o autor e os termos daquela discussão congressual, induzia a se pensar que somente sob um governo como o da segunda etapa da revolução é que adviriam as verdadeiras mudanças (idem); nesta hipótese, o protagonista desconhecendo o tempo real como lugar de um agir efetivo e construtivo. 
Divisar o caso brasileiro à luz dos textos de Lênin sobre a Revolução russa de 1905 significava grande abertura analítica. ${ }^{43}$ Todavia, para pensar a práxis do curto termo, Alberto Passos Guimarães avaliava o valor das mudanças que haveriam de processar-se na primeira fase da revolução conforme se destinassem a manter ou destruir a "velha ordem de coisas" (cf. Lênin). Citemos o autor: "Em relação às tarefas da revolução antiimperialista, podem considerar-se revolucionárias todas as transformações burguesas (sejam simples reformas ou mudanças profundas) que simultaneamente resultem na destruição dos laços com o imperialismo e expressem um tipo de desenvolvimento independente baseado no capitalismo de Estado e no capital privado nacional. Em relação às tarefas da revolução antifeudal, podem considerar-se revolucionárias as transformações burguesas, sejam reformas ou mudanças profundas, que simultaneamente resultem na destruição dos laços com o feudalismo, na destruição das relações pré-capitalistas e expressem um tipo de desenvolvimento democrático baseado no capitalismo de Estado e na propriedade camponesa" (idem). Fica aí sugerido que nossa modalidade de revolução pressupunha uma ideia de complementaridade das mudanças que haveriam de se concretizar sob diferentes graus e em tempo continuado.

Colocar o cenário de uma revolução burguesa democrática não só trazia o tema das coligações e da hegemonia como atribuía função decisiva à conduta do ator. Caso agisse segundo um plano ou estratégia e visasse metas com "firmeza" e "segurança", o processo poderia desdobrar-se até chegar ao novo tipo de governo e de poder. É sob esse registro de uma revolução progressiva por etapas que Alberto Passos Guimarães delineia o "caminho brasileiro ao socialismo". Para ele, quanto mais clara a delimitação das duas etapas e das tarefas relativas a cada uma delas, mais se distinguiria no processo anti-imperialista e antifeudal - este largo período

\footnotetext{
${ }^{43}$ Leia-se a referência de Passos Guimarães "No Brasil de nossos dias o problema do caráter das transformações de nossa sociedade só pode ser equacionado nos termos que Lênin o colocava. Não há nas presentes condições brasileiras um curso apenas, um caminho apenas para o desenvolvimento do capitalismo mas dois cursos ou dois caminhos: o reformista, seguido pela parte conciliadora da burguesia, é o da acomodação, da associação ou da subordinação ao imperialismo e aos restos do feudalismo" (Passos Guimarães,1960a). O autor não deixa evidente a associação desse tema à questão democrática no sentido que se conhece em outros autores pecebistas. Observe-se ainda que Passos Guimarães usa o termo reformista na mesma acepção que aparece no opúsculo leniniano de 1907, como sinônimo de conservador (idem)
}

que o autor divisava na "revolução nacional" - "as fases evolutivas de desenvolvimento gradual que se realizam dentro de cada etapa e os saltos ou transformações radicais que marcariam a passagem de uma para outra etapa, entre as simples mudanças na correlação de forças que correspondem às fases de uma mesma etapa histórica e as mudanças na correlação de classes (substituição de classes no poder) que correspondem à passagem a uma nova etapa histórica" (idem).

Sob formalização marxista-leninista, Alberto Passos Guimarães reivindica nos seus textos a tarefa de prosseguir com a "correta compreensão" do caminho brasileiro iniciada com a Declaração de Março.

É certo que ainda compartilha o velho "objetivo final" da conquista sob hegemonia do proletariado - de um novo poder anti-imperialista e antifeudal que transite até o socialismo. ${ }^{44}$ Note-se, contudo, o empenho do autor em perquirir nossas peculiaridades justamente pondo atenção neste ponto da projeção dos primeiros tempos do caminho brasileiro ao socialismo. Citemo-lo de novo na questão decisiva: o inevitável "período intermediário" que ia da conjuntura que então se vivia a um futuro próximo e ao regime "a que se deverá chegar após esse período intermediário, ou seja, o poder das forças anti-imperialistas e antifeudais" (idem). Passos Guimarães traduzia para um tempo mais ou menos próximo o cálculo estratégico alimentado pela doutrina, tentando divisar um momento (do "período intermediário") como um mundo real e já tangível ao redor daquele ano 1960, tempo marcado por movidas variações da conjuntura.

Essa é a questão real que não recebera tratamento "com toda a indispensável minudência, a fim de que possamos divisar - diz o autor claramente a natureza, a profundidade e a extensão das mudanças que durante ele deverão verificar-se a partir do atual regime político até sua substituição por um novo regime" (idem). No plano da política, no qual o ator revolucionário tem vida pública, tratava-se de responder à indagação de se nesse período poderia ocorrer uma recomposição do Estado "com a saída de

${ }^{44}$ Leia-se no autor: "Diga-se de passagem que o tipo de poder das forças anti-imperialistas e antifeudais proposta como objetivo final nas Teses não difere, quanto ao seu conteúdo do tipo de poder proposto como objetivo final no Programa de 1954 (governo democrático popular ou ditadura das forças antifeudais e anti-imperialistas) a não ser pela precedência que é dada no último às forças antifeudais. Ambos pressupõem no entanto, um traço essencial comum - a hegemonia do proletariado" (idem) 
umas e a entradas de outras classes e camadas sociais" (idem). Citemos sua formalização: "A resposta a esta pergunta exige que ampliemos, e aprofundemos, os nossos conhecimentos a respeito das seguintes questões: 1) quais as classes e camadas que participam, atualmente, do poder; 2) quais as classes e camadas que na atual etapa ou num futuro imediato poderão ser desalojadas do poder; 3) quais as classes e camadas que, na atual etapa ou num futuro imediato substituirão as camadas que serão desalojadas e 4) qual a classe que agora detém a hegemonia e qual a classe às mãos da qual passará na atual etapa ou num futuro imediato a hegemonia política" (idem). É assim que o autor, usando esquema classista, centraliza na recomposição do Estado sua controvérsia sobre a revolução em tanto problemática do presente - ao tempo que também descrevia no processo revolucionário alterações seguindo a sequiência que aparece nos textos da "nova política": governo, regime e estado. ${ }^{45}$ Apenas à primeira daquelas indagações as Teses ofereciam resposta, diz Alberto Passos Guimarães citando a tese 18: "Atualmente o Estado brasileiro representa os interesses dos latifundiários, dos setores capitalistas ligados ao imperialismo (comerciantes, industriais associados a capitais monopolistas estrangeiros) particularmente norte-americano e também da burguesia interessada no desenvolvimento independente da economia nacional" (Passos Guimarães, 1960a). No entanto, acrescentava ele, no raciocínio desenvolvido em outras proposições, as Teses não resolviam a questão maior do curso da revolução burguesa. Citemo-lo no texto ora comentado, na passagem em que o autor volta a relevar o ponto subentendido nas Teses: o de que em todo o processo da revolução anti-imperialista e antifeudal "só haverá um desenlace no momento em que o poder passará das mãos dos latifundiários, dos setores capitalistas ligados ao imperialismo, particularmente o norte-americano e também da burguesia interessada no

\footnotetext{
${ }^{45}$ A propósito da questão do Estado, observe-se que as Teses repetiam este trecho que abre o tópico da Declaração de Março de nome "A democratização da vida política nacional": "O desenvolvimento capitalista do país não podia deixar de refletir-se no caráter do Estado brasileiro, em seu regime político e na composição do governo" (PCB, 1958; 1982: 8). O tema volta num tópico das Teses sugestivamente chamado: "As classes sociais, o Estado e as instituições do Brasil". Não se tem até aqui registro da origem dessas referências (ao modo de $O$ dezoito brumário). Esse ponto sobre o caráter do Estado brasileiro reaparece na caracterização do regime de 1964 que o Informe de Balanço ao VI Congresso de 1967 faz em um tópico chamado "A mudança do regime político", onde se lê que o golpe militar não havia sido simples mudança de governo, mas "modificou profundamente a forma estatal de poder, com danos incontáveis para os interesses da maioria do povo e do conjunto da nação" (PCB, 1967; 1980). (Grifos do autor destas notas).
}

desenvolvimento da economia nacional diretamente às "forças antiimperialistas e antifeudais" (idem).

Posto esse cenário mais distante nas Teses, o "período intermediário" figuraria como um "mero interregno durante o qual nenhuma classe ou camada cederá o lugar a nenhuma classe ou camada, embora possa haver um governo ou uma sucessão de governos com nuanças políticas pouco demarcadas" (idem). Passos Guimarães exige que se dissesse que, antes da passagem a um novo regime das forças anti-imperialistas e antifeudais (o futuro incerto da doutrina), "as condições estarão dadas para outras modificações na composição do Estado brasileiro" (idem). O "período intermediário" constituía-se em uma "etapa histórica", "específica" da revolução brasileira. ${ }^{46}$ Alberto Passos Guimarães completa esta questão da fase intermediária ("representada pela mudança no poder de determinadas classes e camadas") retornando ao tema do processo da revolução antiimperialista e antifeudal como um período que, diz ele, "segundo posso entender, desdobra-se em duas etapas: a etapa nacional e democrática e a etapa democrático-popular" (grifos nossos). Mesmo ao modo antigo, o autor recortava tema vivo e de interesse prático para aquela fase do pré-64 na qual os comunistas e as demais esquerdas tinham de atuar ao dia, se quisessem manter seu horizonte doutrinário (no caso, "a etapa democrático-popular") com algum contato com a realidade efetiva posta diante deles. Ademais, lembre-se que o publicista via a intervenção do ator de orientação marxistaleninista em termos de uma estratégia ou "arte" da política (Lênin).

Vê-se quão difícil era para Alberto Passos Guimarães converter a lucidez que o PCB obtinha a cada dia numa compreensão do agir para o

${ }^{46}$ Aquele ponto lembra a questão das vias ao socialismo, a propósito da qual, em seu texto Crítica ao Programa de Erfurt, Engels dizia: "Uma coisa absolutamente certa é que nosso Partido e a classe operária não podem chegar a dominação senão sob a forma da república democrática. Esta última inclusive é a forma específica da ditadura do proletariado, como já o demonstrou a Grande Revolução Francesa" (Engels, 1891; 1973). Recorde-se que Engels conhecera os resultados das revoluções econômicas "pelo alto" (expressão dele) subsequentes à derrota das revoluções europeias de 1848. Engels tem outras passagens sugestivas, o prussianismo estando presente nas suas últimas reflexões ("Introdução" a As lutas de classes na França de 1848 a 1850) sobre o método democrático ao socialismo (Engels, 1895; 1977). No entanto, é Sodré o autor brasileiro da época (Sodré, 1962) mais próximo dessa referência na qual Engels associa ao padrão prussiano da modernização a valorização da democracia no contexto de avanço progressivo da social-democracia alemã no final do século XIX. (Ver, especialmente, Engels, 1891; 1973). 
curto e o médio prazos consultando os objetivos doutrinários. Com efeito, nos últimos tópicos do texto sobre as etapas, o autor retoma a fala nova permeada pelo marxismo-leninismo. Voltando aquele tema das etapas (que não seriam estanques, tarefas de uma passando para outro tempo), Passos Guimarães diz que as diferenciava, por um lado, com base no deslocamento de classes e camadas no poder (na primeira etapa, saída das classes mais atrasadas e ligadas ao neocolonialismo; na segunda, a de grupos capitalistas vinculados ao imperialismo, os latifundiários burguesas e outras camadas mais reacionárias); e, por outro, que também distinguia as etapas conforme as tarefas programáticas (na primeira etapa, medidas para deter o imperialismo e impulsionar a revolução agrária que "não passará de uma reforma agrária inicial (e ainda não camponesa) que varra os vestígios caducos do escravismo e do feudalismo"; e numa segunda, tarefas visando extinguir a dependência e a "instituição de uma reforma agrária radical" de tipo camponês "que transformará por completo a estrutura agrária" (Passos Guimarães, 1960a). Voltaremos a este ponto agrário no próximo tópico, apresentando-o como uma argumentação que distingue o publicista.

É possível afirmar que há naquele tipo de revolução descrito por Alberto Passos Guimarães uma visão não rupturista. Suas ideias sobre o "período intermediário" e a sucessão das etapas diziam muito do sentido progressivo da nova política: "Assim como no curso da primeira etapa poderá haver fases táticas diversas, como modificações de grau na composição dos governos de caráter nacional e democrático que nos aproximarão do último limite da revolução burguesa, assim também no curso da segunda etapa poderá haver fases táticas diversas e sucessivas nas modificações diversas na composição do governo, à medida que fosse crescendo o peso específico dos operários e seus aliados naturais e particularmente no seio das forças anti-imperialistas e antifeudais" (idem). Mesmo quando o autor se refere simultaneamente ao tempo real e aos fins últimos tal sentido aparece: "As modificações na composição dos governos da primeira etapa por aproximação da passagem para a etapa seguinte e as modificações na composição dos governos da segunda etapa nos conduzirão ao nosso ulterior objetivo histórico - a vitória do socialismo" (idem).

Usando a caracterização da posse do poder, Alberto Passos Guimarães demarcava o campo da política para o agir no tempo presente e próximo. No contexto de 1960, a dois anos da Declaração de Março, o autor se empenha em desconstruir a tese de alguns publicistas do V Congresso que diziam que a burguesia já estaria participando do Estado como um todo, ou como classe, dito assim com a intenção conceitual da época. Quer dizer, que tal hipótese levava - equivocadamente, anota Passos Guimarães, retomando ponto anterior - a se pensar que aqui "não há mais nenhuma revolução nacional a realizar", pois já se concluíra o período das transformações anti-imperialistas e antifeudais e se passava ao tempo novo de uma revolução fundamentalmente antiburguesa e anticapitalista. Ao contrário, prossegue o autor, dizer que "A aspiração da burguesia brasileira é, por isso, a de criar um Estado nacional independente em que ela seja a força dominante", como estava nas Teses, propiciava aos atores não só a denúncia do governo da época como também a pressionar para convertê-lo "em governo de coligação nacionalista e democrático" (Passos Guimarães, 1960b). Mudar o governo então existente por outro de caráter nacionalista e democrática não era pouca coisa para o ator que se postasse na política corrente. Requeria descortinar um horizonte que supunha organizar-se à luz do dia, estender-se pelo país, buscar entendimentos que lhe agregassem influência; preparar tarefas eleitorais e assim por diante.

Perseguir mudanças de classes no poder - digamos com linguagem daquele tempo -, visando deslocar classes e grupos mais atrasados e toda a burguesia ligada ao imperialismo significava empenhar-se na formação de sucessivos governos de caráter burguês ("nos quadros do regime vigente", cite-se novamente as Teses), ou seja, ter vida bem ativa na conjuntura daquela época.

Nesse ponto, Alberto Passos Guimarães se diz distante das Teses. Enquanto elas viam tais deslocamentos nos governos como mudanças graduais, "como fases de uma mesma etapa", ele as entendia como alterações na "composição do Estado", vale dizer, como "mudanças radicais", qualitativas "e portanto constantes (grifo do autor do presente texto) de duas etapas em vez de uma" (Passos Guimarães, 1960b). Segundo o publicista, faltara às Teses maior congruência entre o "sentido geral" da sua análise justa da situação concreta brasileira" e o "conteúdo revolucionário" da "nova política" (idem). Citemo-lo numa passagem desse segundo texto ("Uma falsificação e vários erros crassos na questão das etapas"), na qual aparece de modo claro o ponto do agir do protagonista na circunstância e mais precisamente na conjuntura. O decisivo para Passos Guimarães consistia em "distinguir e ordenar, desembaraçar e definir objetivos e tarefas que têm que ser realizadas na ordem cronológicas ou 
histórica, isto é, que terão de ser realizadas proximamente. Só assim se terá clareza sobre as linhas divisórias, os 'instantes estratégicos' em que se modificará a composição do poder e sobre que classes deverão ser desalojadas do poder e que classes entrarão no poder" (idem) ${ }^{47} \mathrm{Em}$ suma, para ele, tratava-se de pensar um processo revolucionário "planejado" como tudo naqueles tempos de inteligentsias leninistas e mannheimianas cujos "passos intermediários" em qualquer desses dois registros comunista ou nacional-desenvolvimentista - eram concretizáveis e cumulativos, em direção aos quais se caminharia no tempo real ali disposto e não por gestos à espera de uma revolução futura.

\section{O papel dos sindicatos no "movimento camponês"}

O tema das etapas não constitui toda a contribuição do autor de Quatro séculos de latifúndio ao pecebismo contemporâneo. Há nos seus textos congressuais um equacionamento antinaturalista da questão agrária que merece exame. Nosso interesse agora é chamar a atenção para sua visão alternativa ao protagonismo camponês diruptivo dos modelos das revoluções burguesas europeias de 1848 e russa de 1905. O modo como o publicista põe o problema da interpelação do nosso campesinato débil aponta para uma ideia de revolução agrária que termina sendo vista como uma revolução concretizável mediante procedimentos democráticos. Com todas suas ambiguidades, o autor realiza, no tema agrário, um exercício formulativo que também podemos habilitar como argumento relevante a favor daquele pecebismo gradualista e de frentismo democrático.

Vejamos o lastro que Alberto Passos Guimarães propicia ao agrarismo que o V Congresso de 1960 oficializa. Como foi observado, o autor influíra na Declaração de Março, nela sendo visíveis suas ideias agrárias. No entanto, será nos artigos dirigidos ao V Congresso já citados ("A questão das etapas da revolução brasileira", "Uma falsificação e vários erros crassos na questão das etapas") e em "Três Frentes da luta de classes no campo brasileiro", nos quais o publicista busca substantivar a nova orientação agrária. Como no tema das etapas, Alberto Passos Guimarães

\footnotetext{
${ }^{47}$ Essa referência a "instantes estratégicos" também lembra a ressalva que fazia Engels ao se referir no seu testamento político à quebra da legalidade pelas forças reacionárias "para deter o avanço socialdemocrata ao socialismo por meio do método eleitoral no regime democrático-constitucional do seu país (Engels, 1895; 1977).
}

sustenta sua argumentação no método leniniano da luta de classes que, segundo ele, rompia com a "sociologia vulgar" incapaz de penetrar no "âmago" do problema agrário, "dele tendo-se apenas uma visão estática, um quadro fenomenológico” (Passos Guimarães, 1960c).

Passemos às proposições do autor, particularmente a que se refere a uma variante de revolução agrária diferenciada tanto da fórmula nacionallibertadora (III IC) quanto da própria teoria leninista da revolução democrático-burguesa de novo tipo. O publicista radica seu ponto de partida na fragilidade dos nossos camponeses, aludindo a uma passagem de Lênin em que o teórico russo imaginava a eventualidade de um segundo (segundo em relação ao próprio modelo leniniano no qual o campesinato constitui força primordial) tipo de revolução diverso da matriz originária de Marx e Engels. ${ }^{48}$ Antes, porém, fixemos dois pontos: a) que, como temática, há em Caio Prado Jr. uma clara ideia de revolução não camponesa, conceito este, já veremos, posto em circulação por Lênin em um dos seus textos sobre a revolução russa de 1905; e b) como noção da cena do V Congresso de 1960, aquele conceito leniniano aparece justamente com um dos artigos de Alberto Passos Guimarães.

Para diferenciar o sentido da revolução agrária não camponesa em Passos Guimarães, façamos uma breve referência a Caio Prado. Escrevendo na Tribuna de debates da primeira convocatória do IV Congresso (1947), já tendo publicado Formação do Brasil contemporâneo (1942) e História econômica do Brasil (1945), dizia Caio Prado que - "na forma em que se coloca em geral entre nós a questão da revolução democrático-burguesa" aqui não ocorreria nenhuma revolução como trânsito do feudalismo para a ordem burguesa. A circunstância brasileira consistia em uma economia que desde sua gênese se organizara como economia colonial (Prado Jr., 1947). ${ }^{49}$

\footnotetext{
${ }^{48}$ Considera-se aqui como emblema da matriz dos clássicos o modelo que Engels desenha no seu texto "O Problema camponês na Franca e na Alemanha" (Engels, 1894; 1981).

${ }^{49}$ Vale a pena ver um trecho do artigo "Os fundamentos econômicos da revolução brasileira" (1947): "Não é assim uma economia feudal nem 'relações feudais de produção' que representam a primeira etapa da evolução histórica brasileira. É uma organização econômica que poderíamos designar por 'colonial', caracterizada pela produção de gêneros alimentares e matérias-primas ao comércio internacional e fundada (em seu setor agrícola que é o principal) no sistema de plantação, isto é, num tipo de exploração em larga escala que emprega o trabalho escravo. A substituição posterior do trabalho escravo pelo trabalho emprega o trabalho escravo. A substituição posterior do trabalho escravo pelo trabaho
juridicamente livre (mas submetido de fato a um sem número de restrições) introduziu naquele sistema um poderoso fator de desagregação que o comprometerá definitivamente.
} 
Recordemos que o autor já cogitava que aqui teríamos uma revolução sem classe econômica forte e protagonista e que também já tinha em mente que o processo brasileiro tampouco contaria com um campesinato revolucionário. Estaríamos diante de um capitalismo socialmente excludente e sem condições para reestruturar-se caso não adviesse grande intervenção do poder público. Vale dizer, estávamos ante uma modernização cuja revitalidade residia no renovamento do mundo agrário que, no entanto, não seria liderado por um campesinato ativo.

Em Caio Prado, a "revolução nacional" dependia menos de um antiimperialismo unificador do espírito nacional e sobredeterminante das demais contradições e conflitos, como nos exemplos sempre citados das resistências anticolonialistas. Entre nós, a questão nacional consistia no grande esforço para tornar o capitalismo existente mais produtivo e incorporador. Ao contrário da fórmula antifeudal e anti-imperialista, Caio Prado Jr. radicava a revolução numa "contradição fundamental" (noção da época) de outro tipo: a incapacidade de um capitalismo de tornar produtivos vastos contingentes sociais, sobremaneira os desvalidos do mundo rural. Daí a fórmula caiopradiana da revolução agrária e nacional sugerir uma reestruturação ao modo americano no sentido de um Oeste-mercado interno (mundo rural) que complementasse um Leste-industrial. "Oeste" pensado como uma revolução não camponesa conquanto seria uma grande mobilização assentada na proteção de direitos dos grupos mais expressivos da força de trabalho empregada nos grandes setores da agropecuária. Esse "movimento social reivindicativo" (sic) viria universalizar processos sociopolíticos sob a liderança de sindicatos espalhados pelos municípios brasileiros à frente de reivindicações por salário e ocupação sobretudo daquele núcleo estratégico dotado de melhores condições para difundir impulsos renovadores na economia agrária de modo sustentável.

Mas não modificou fundamentalmente, desde logo, os quadros essenciais da estrutura agrária vigente. E é precisamente aquela contradição introduzida no funcionamento primitivo do sistema agrário pela libertação do trabalho que constituirá o fator máximo de transformação econômica e social ora em curso e que devemos revolucionariamente levar a seu termo".

\section{Lênin e a revolução agrária não camponesa}

Vejamos agora como a ideia de revolução agrária não camponesa circula no V Congresso com Alberto Passos Guimarães. Leitor dos textos leninianos sobre a revolução burguesa na periferia capitalista, o publicista figura entre os primeiros a se referir às formas farmer e prussiana de evolução do atraso rural para o moderno, descritas pelo marxista russo em O programa agrário da social-democracia russa (1907). Em Passos Guimarães tanto há menções a traços prussianos em processos de nossa modernização rural, como mencionaremos mais adiante, quanto o uso do conceito de revolução agrária não camponesa. Em "Três frentes da luta de classes no campo brasileiro", o autor retoma o tema da revolução agrária a partir do cenário de um mundo colonial diverso do modelo da III IC, levantando a hipótese de podermos conhecer aqui uma revolução democrático-burguesa com um campesinato bem pouco "desenvolvido". Com essa tematização, Alberto Passos Guimarães diferencia o "problema camponês" tanto da vulgata marxista-leninista (não o subsumindo à noção de aliança operário-camponesa) que marcava áreas importantes do partido comunista quanto em relação à ideia caiopradiana de revolução não camponesa protagonizada do "começo ao fim" do processo revolucionário por grupos "não camponeses".

Em "Uma falsificação e vários erros crassos na questão das etapas", o autor recorre a passagens do opúsculo leniniano de 1907 quase desconhecidas na cena pecebista, delas extraindo justamente o conceito de revolução agrária não camponesa. ${ }^{50}$ Passos Guimarães traz o conceito para registrar ser possível aqui um processo de transformação agrária conforme a hipótese de Lênin: com lógica e forma diversas da revolução camponesa antifeudal. Anote-se que, no autor russo, trata-se de uma modalidade que ocorreria nos países dotados de agricultura totalmente capitalista ou naqueles outros casos em que o seu "regime agrário" já se achava tão "amalgamado" com a "economia capitalista em geral" que "seria impossível destruir este regime sem destruir o capitalismo" (cf. Passos Guimarães, 1960b). Esse tipo de revolução poderia ser liderado por outras classes (no exemplo do próprio Lênin, burguesia industrial e proletariado) e

${ }^{50}$ Há um ensaísta bem posterior que faz referência à hipótese leniniana acima aludida em um registro sobre a relação entre o encaminhamento do tema agrário e o formato do político (Vianna, 1976). 
teria por objetivo abrir caminho para o capitalismo agrário. Alberto Passos Guimarães retinha a problematização leniniana para repensar o problema camponês brasileiro, citando do opúsculo de 1907 esta passagem: "Em outras palavras, é possível um país burguês sem camponeses. É possível uma revolução burguesa em um país de considerável população camponesa e que, não obstante, essa revolução não seja camponesa, isto é, seja tal que não revolucione as relações agrárias que afetam em especial os camponeses e não destaque estes entre as forças sociais, sequer ativas, executoras da revolução" (idem). Sublinhe-se o final dessa citação conquanto será ela elemento distintivo na apropriação que Alberto Passos Guimarães faz do leninismo em relação aos temas agrário e da mediação camponesa.

Diferentemente de Caio Prado Jr., nosso ensaísta não leva às últimas consequências a ideia de revolução agrária não camponesa. Ele traz o conceito leniniano para um ponto sobre o qual atribuía importância decisiva: o fato de o Brasil ser "um país de campesinato recente, de movimento camponês atrasado", tudo ainda por se desenvolver por meio da luta de classes. Também aqui poderia ter andamento uma revolução (uma "reforma agrária", como chamava ao tom daqueles tempos) que viria dizia o autor bem próximo das palavras do marxista russo - " "revolucionar' várias relações agrárias que afetam os camponeses mas não os afetam em especial, tais como a destruição de muitos vestígios medievais, feudais, escravistas" (idem). Por esta proposição, Alberto Passos Guimarães diz que a brasileira seria uma revolução rural que começaria a partir de uma base de apoio criada pela luta de classes, isto é, por meio de um "movimento" não camponês. Ela poderia iniciar-se a partir de uma mobilização de assalariados e semiassalariados agrícolas (ou, repetindo os termos das Teses: ter suas "bases iniciais" nos sindicatos que o PCB organizava com vistas a alcançar o campesinato). Reafirmando a Declaração de Março e o caminho andado até a organização da Ultab, em 1954, assim as próprias Teses definiam o novo caminho: "A fim de impulsionar a organização das massas do campo, é necessário atribuir uma atenção primordial aos assalariados e semiassalariados agrícolas. Em virtude da sua condição social de proletários ou semiproletários, como também do seu grau de concentração, os assalariados rurais são mais suscetíveis de organizarem-se em sindicatos que podem constituir as bases iniciais para a mobilização das massas camponesas. Essa mobilização exige, igualmente, que se parta das condições atuais do movimento camponês e se tomem por base as reivindicações mais imediatas e viáveis como a baixa das taxas de arrendamento, a prorrogação dos contratos, a garantia contra despejos, o pagamento do salário mínimo, a legitimação das posses etc., não devendo ser propostas, no trabalho prático, palavras de ordem que ainda não encontram condições maduras para a sua realização. Também no campo, a prática demonstra que a atuação através das formas legais de luta e de organização é aquela que permite às massas alcançar êxitos, devendo ser estudadas e adaptadas às condições de cada região as experiências das ligas camponesas, associações rurais e cooperativas, bem como impulsionada a organização dos assalariados e semiassalariados agrícolas em sindicatos. No processo de associação dos assalariados e dos camponeses é de grande importância a defesa jurídica dos direitos que lhe são assegurados. A ação das massas camponesas é indispensável para vencer a resistência dos latifundiários no Parlamento e conquistar a aprovação de leis que atendam aos seus interesses, inclusive a elaboração de uma legislação trabalhista adequada ao campo. Em torno da reforma agrária, necessidade hoje nacionalmente reconhecida pelas forças do mais variado caráter, cumpre aos comunistas elevar suas atividades entre as massas. A reforma agrária deve tornar-se bandeira dos próprios camponeses, o que coloca em primeiro plano a questão das formas de sua mobilização e organização, a fim de que avancem por sua própria experiência política" (PCB, 1960; 1982: 72-73).

O eixo desse agrarismo consistia, assim, em uma mediação organizacional habilitada a operar uma mobilização de porte visando envolver a grande massa dos camponeses. Em termos a que muito se parecem as palavras das Teses, diz Passos Guimarães: "E, à medida que os camponeses forem levados a participar do movimento agrário, conduzido pelo proletariado em aliança com este, a reforma agrária ainda não camponesa se transformará numa reforma agrária camponesa, o que acontecerá na segunda etapa da revolução anti-imperialista e antifeudal" (Passos Guimarães, 1960b). Essa grande movimentação social - o "movimento camponês" - era concebido como uma articulação entre aqueles dois contingentes, coligados, desde logo, com os operários urbanos, a classe revolucionária que haveria de levá-los, sob sua direção - reitera o autor (no sentido da tese da aliança operário-camponesa) - a participar da frente única "nacional" e "democrática", a composição política que daria vida ao processo revolucionário no Brasil nos seus primeiros tempos (idem). 
Entretanto não se pode minimizar o fato de que a "nova compreensão" de 1958 entendia o problema agrário não como questão nacional, mas como uma segunda "contradição fundamental" determinada pela dependência. À lógica desta última circunstância se subsumiriam os demais tensões da formação social; o anti-imperialismo se constituindo em contradição sobredeterminante. Além de expressar aquela época desenvolvimentista, a principalidade que se sublinhava naquele postulado ainda recebia certa influência conceitual da Revolução Chinesa na qual a luta nacional contra o invasor estrangeiro fora vitoriosa (categorias como: "contradições", "contradição principal", etc.). Assim, o ponto forte do ensaísta se ofusca à hora que o autor ajusta a fórmula leniniana à questão da dependência na periferia capitalista. Como que se dilui a densidade das citações do clássico a que recorre o comunista brasileiro ao equacionar a "revolução nacional" na encruzilhada dos caminhos prussiano ou revolucionário; vigor este que Alberto Passos Guimarães também exibe quando se volta para o tema da debilidade do nosso campesinato no registro dos "restos feudais", todavia parecendo ter em mente os textos leninianos citados.

De qualquer modo, o autor constrói argumentação em suporte à "nova política" com base em um cânone ao mesmo tempo de interpretação e programático. Trata-se da luta de classes, o "elemento dinâmico", como a chama, movido contra o "naturalismo histórico", viés que, segundo ele, leva à proposição de que o avanço do desenvolvimento capitalista torna desnecessária a reforma agrária (Passos Guimarães, 1963). O ponto específico do qual parte nosso ensaísta leninista - também autor nacional-desenvolvimentista ao falar a outra linguagem daquele tempo - consiste na "luta das classes em ascensão" (grifos do autor destas notas). Ou seja, esse fio condutor "que nos levará a descobrir as leis gerais e particulares do desenvolvimento social" (Passos Guimarães, 1960c). Passos Guimarães concentra seu olhar naquele bem preciso "elemento dinâmico que aciona o progresso social" (sic), nas novas classes: o proletariado, os camponeses e a intelectualidade.

$\mathrm{O}$ autor considera o campesinato como um grupo emergente (idem) dentre as classes convocadas a abrir caminho progressista ao desenvolvimento capitalista. Acrescente-se a seguinte observação com que Passos Guimarães qualifica o "ponto de vista do proletariado" a que serve sua publicística: ${ }^{51}$ o proletariado se distinguia das classes oprimidas pela burguesia - diz ele citando a Lênin - como aquela classe que não cifrava suas esperanças "sobre uma interrupção do desenvolvimento burguês; não sobre o enfraquecimento ou atenuação da luta de classes, mas ao contrário sobre seu desenvolvimento mais completo e mais livre", cf. idem). Aliás, esse era um tipo de tematização que aproximava o pensamento comunista "péssimo" na teoria e lúcido e responsável quando referido à prática (Jaguaribe, 1977, apud Marçal Brandão, 1992) - da cena intelectual-política que os autores isebianos e cepalinos construíam com muita competência.

Como vimos no tópico anterior, Alberto Passos Guimarães olhava os anos desenvolvimentistas ancorado nas teses leninistas sobre a revolução na periferia capitalista. Reconhecer como inevitável a modernização (de conteúdo econômico e social burguês, este o aspecto "objetivo" do problema) importava atentar para a encruzilhada que estava posta ao país: as rotas conservadora e progressista. A circunstância de um industrialismo retardatário numa periferia capitalista realçava como tema crucial da revolução brasileira a questão das coligações que disputavam a hegemonia do nosso curso modernizador.

É nesse quadro conceitual que o autor põe o tema agrário na revolução. Segundo ele, aqui também não se avançara: a raiz da "compreensão nova" não aparecera de forma clara na Declaração de Março e ainda não estava posta nas Teses do V Congresso. Alberto Passos Guimarães ia diretamente a $O$ programa agrário da social-democracia russa: "Dois são os caminhos possíveis do desenvolvimento capitalista no campo brasileiro: um, revolucionário, outro, reformista" (Passos Guimarães, 1960c). A ser apoiado pelo proletariado - retoma o leninismo o primeiro deles consistiria em transformações burguesas "que resultem na destruição dos laços com o feudalismo, que resultem na destruição das formas pré-capitalistas, e expressem um desenvolvimento democrático apoiado no capitalismo de Estado e na propriedade camponesa" (idem). Já o caminho "reformista" (aqui as aspas devido ao uso do termo para referir-se à via junker) também imporia ao mundo rural mudanças burguesas, mas

${ }^{51}$ A noção "ponto de vista do proletariado" é tomada de Adolfo Sánchez Vásquez em sua crítica ao teoricismo da obra de Althusser (Vásquez, 1978). 
sem alterar as bases do ancien régime. ${ }^{52}$ Ainda nessas passagens sobre aquelas duas vias, Passos Guimarães adicionava uma segunda qualificação que extraía da circunstância nacional, a saber: as transformações burguesas poderiam realizar-se sob formas diversas "e o tem sido no Brasil quer de forma violenta, quer de forma pacífica, sem ou quase sem violência" (idem). Esse tema se faz presente em Quatro séculos de latifúndio, e acompanha passagens dos textos congressuais, particularmente do artigo ora em exame.

Esse ponto da "forma de luta" (linguagem da época) não reflete apenas interesse historiográfico e voluntarismo do nosso autor. Constitui um elemento condicionante das possibilidades do novo agrarismo. Os capítulos de Quatro séculos de latifúndio dedicados aos três primeiros séculos da Colônia realçam a forte presença da violência no mundo rural. Desde o uso direto na época da constituição da grande propriedade estamental, passando pela estratificação no sistema rígido da casa-grande até os choques com os "intrusos" e "posseiros" que espreitavam os grandes domínios (Passos Guimarães, 1963). No terceiro texto congressual, o autor registra que, após todo um tempo penoso de conflitos e levantes de escravos, o movimento abolicionista concluíra-se como uma vitória pacifica. A Abolição constitui o primeiro emblema de uma via que abre caminho para novas relações econômicas e sociais e adquirira "importância revolucionária", mesmo tendo se conservado o monopólio da terra (Passos Guimarães, 1960c). Sublinhava que 1888 trouxera um tempo de "transformações burguesas de conteúdo revolucionário", antecedendo a outras mudanças que seriam também obtidas por meios pacíficos mediante "reformas" (as aspas devido à conotação

${ }^{52}$ Merece um excurso a leitura conjunta de Duas da social-democracia russa e de $O$ programa agrário da social-democracia russa como textos nos quais Lênin expõe sua teoria da revolução burguesa de novo tipo. No primeiro deles, Lênin esclarece as vantagens do caminho capitalista revolucionário: "Em países como a Rússia, a classe operária sofre não tanto do capitalismo como da insuficiência do desenvolvimento do capitalismo. Por isso a classe operária está absolutamente interessada no mais amplo, mais livre e mais rápido desenvolvimento do capitalismo. É absolutamente vantajosa para a classe operária a eliminação de todas as reminiscências do passado que entorpecem o desenvolvimento amplo, livre e rápido do capitalismo" (Lênin, 1905; 1975). Observe-se que a Declaração de Março considera o desenvolvimento capitalista como o "elemento progressista por excelência" da economia brasileira do tempo contemporâneo. Repetido nas Teses do V Congresso, esse desenvolvimentismo provocou uma reação ortodoxa ao que então se chamou de "objetivismo" burguês prussiana acima referida). Alberto Passos Guimarães alude às ações mais contemporâneas de posseiros pela validação dos títulos de suas propriedades. $\mathrm{O}$ ponto alto desses conflitos tensos, porém bem-sucedidos, será a expropriação do Engenho da Galileia. Sob o curso "normal" dos acontecimentos, o conflito foi igualmente exitoso ("Apesar de concretizada mediante uma 'reforma' concedida pelo governo, a expropriação não teve conteúdo reformista, não se fez para conservar as velhas relações de produção existentes", cf. idem). Ante um novo emblema, o autor diz que eventos como aqueles se repetiriam "em elevada escala" à medida que a luta de classes tivesse curso livre e o movimento camponês se fortalecesse. ${ }^{53}$

Realcemos que Alberto Passos Guimarães retém daquelas referências tema essencial: a "forma pacífica é mais vantajosa e mais eficaz do ponto de vista da prática revolucionária, que a forma violenta." Ele anota que o recurso à violência verifica-se com mais frequência em processos "prussianos" (de cunho "reformista" por representar "uma conciliação com as formas de dominação correspondentes a regimes historicamente superados", cf. idem). Nessa passagem, o autor põe como exemplo o caso da evolução do "latifundismo feudal para o latifundismo burguês, principalmente na agricultura cafeeira", onde, registra ainda, em muitos casos, a classe opressora tomara a iniciativa de recorrer a meios violentos (idem).

Atualizada pelo conflito da Galileia, a questão do curso "normal" dos acontecimentos em sistema político aberto será visto como terreno propício ao alargamento organizacional e à concretização das mudanças agrárias. $\mathrm{O}$ autor sugeria que, dinamizada, a frente única "nacional e democrática" criava oportunidades políticas a que os protagonistas podiam recorrer para levar os conflitos a "desfecho pacífico". Essa era uma vantagem construída no contexto de uma coligação entre vertentes reformadoras, no seio das quais havia lugar para o grupo social da Galileia. Residia no ambiente políticodemocrático e nessas interconexões a possibilidade de se "transformar os exemplos isolados de nossa história em regra de conduta da luta de classes no campo, isto é, se conseguirem (as forças reformistas) multiplicar por toda parte as reformas (pacíficas) de conteúdo revolucionário" (idem). Os obstáculos a tal caminho dependeriam da reação conservadora e da

53 Chama a atenção o fato de Pernambuco ser emblemático tanto para Alberto Passos Guimarães (o Engenho da Galileia) como para Caio Prado que às vésperas de 1964 tomava como modelo do seu agrarismo as greves ocorridas em 1963 na zona da Mata daquele Estado. 
resistência que lhe interpusesse o movimento democrático, termo com que o autor aludia ao conjunto dos grupos coligados na frente única da época. Inclusive, nessa correlação de forças, o fato de o próprio uso da violência "passar às mãos dos inimigos do povo" assumia "transcendental importância como fator político favorável à mobilização das massas populares e ao desenvolvimento da revolução" (idem), diz Alberto Passos Guimarães sugerindo que, sob o regime democrático, é por demais valioso ao protagonista ter iniciativa no campo da política.

\section{Os fundamentos práticos da mediação política}

Após apresentar esses traços do "movimento camponês", o autor retoma o cânone da luta de classes "sob um outro aspecto". Relembremos que para ele a luta de classes não só constitui método adequado aos estudos de história agrária como também assinala o "caminho brasileiro" da revolução "antifeudal". O texto "Três frentes da luta de classes no campo brasileiro" traz uma pequena narrativa sobre o atraso do campesinato que suscita no autor uma estratégia para estimular o livre desenvolvimento da luta de classe no mundo rural. Nesse texto, Alberto Passos Guimarães passa do registro da debilidade camponesa à outra linha argumentativa, de sentido "mais prático": ao tema da mediação requerida para a ativação da luta de classes dos grupos agrários (ainda sem "caráter aberto e consciente", cf. Lênin).

Referindo-se ao campesinismo ("exagerado") dos anos da Guerra Fria, Alberto Passos Guimarães faz esta observação aparentemente trivial: "Partindo de premissas certas de que havia forte semelhança entre a situação de miséria e opressão feudal em nosso país e a de vários países asiáticos e do leste europeu, os comunistas tiravam conclusões erradas sobre uma inexistente analogia entre o grau de maturidade do movimento camponês brasileiro e o de outras partes do mundo" (idem). À circunstância de termos aqui um campesinato "muito recente" somava-se o fato de que, diversamente da experiência de outros países, nossa história conhecera "um número de levantes camponeses que se contam nos dedos". Na Rússia, até 1905, haviam ocorrido mais de 2000 levantes de importância. No Ocidente da Europa havia casos de guerras camponesas que perduram por séculos, para não falar da China, continua o autor, de tradição mais milenar ainda, onde tiveram curso as revoluções de 1928-37 e de 1949. Enquanto entre nós, as transformações do mundo rural foram de outro tipo, inclusive a
Abolição, a mais radical delas - emblema dos clássicos - resultara inclusive de um movimento "impulsionado e dirigido pela pequena burguesia urbana" (idem), o qual, como já mencionado, tivera desenlace no contexto de um curso "normal" dos acontecimentos, no ocaso do Império e do seu sistema político elitista.

Ainda segundo o autor, o atraso do "movimento camponês" não era só em relação às ações e levantes rurais daqueles países mas também se mantinha descompassado com respeito ao próprio "movimento democrático em geral" que, nos anos posteriores ao 24 de agosto de 1954, rapidamente se expandira adquirindo ampla composição. O protagonista revolucionário necessitava entender essa especificidade e já não mais recorrer a "meios artificiais" para alcançar o campesinato. Meios que só levavam os protagonistas a militar em uma "imaginária" revolução rural "com a imposição de práticas aventureiras e desesperadas, completamente desligadas da realidade" (idem). Seria esse o caso de se cogitar em mover quatro ou cinco dezenas de quadros para "levantar os camponeses" "distribuídos por dois milhões de estabelecimentos agrícolas ao largo do país." Diferente disso, a "nova tática de mobilização de massas no campo" (sic) consistia numa mediação política referida a uma dinâmica social assentada em relações entre classes e interesses, em contexto organizacional de tipo permanente (os sindicatos).

Pela linguagem com que valoriza o papel dos sindicatos, à primeira vista parece que Alberto Passos Guimarães apenas reflete o obreirismo dos PCs, seguindo a fórmula leninista-staliniana da aliança operário-camponesa e seu pressuposto de "classe universal" urbana. No entanto, observe-se que o autor não perde de vista as singularidades anteriormente referidas - a "contemporaneidade" do campesinato brasileiro, sua pequena tradição de conflitos e debilidade organizativa. Inclusive a periodização (desde a gênese) utilizada pelo autor para reconstituir o "desenvolvimento da luta de classes no campo" tem um sentido valorativo do protagonismo camponês. Este ponto historiográfico marca Quatro séculos de latifúndio. Os capítulos dedicados aos primeiros tempos dos "senhorios" e dos "intrusos" e "posseiros" compõem a circunstância de enorme dependência sob a qual emergem os desvalidos rurais; tema ao qual retornaremos ao final destas notas. Por ora, realcemos, em "Três frentes da luta de classes no campo brasileiro", a referência ao fato de a "luta de classes no campo" em seu curso contemporâneo e mais recente ter se desenvolvido cada vez mais 
(naquele tempo) por "via pacífica e concessões de governo" (Passos Guimarães, 1960c).

Nessa passagem desse texto, o autor volta a se referir ao campesinismo pecebista ("foquista" e de "zonas liberadas", de inspiração maoísta) dos anos da Guerra Fria. É sob esse prisma autocrítico que dedica um tópico à ênfase na mobilização dos "empregados agrícolas", grupo no qual, recorde-se, Caio Prado assentava o "movimento social” não camponês do "começo ao fim" da revolução agrária. Citemos Alberto Passos Guimarães: "Afastando-se dessas delirantes fantasias (enviar "missionários" a dois milhões de estabelecimentos rurais para ativar os camponeses, RS), as 'Teses' apontam a maneira certa de atingir em larga escala as massas do campo através dos assalariados e semiassalariados agrícolas, organizando-os por meios legais em suas associações de classes, despertando-os para a luta por seus direitos e reivindicações, elevando o grau de consciência da sua luta de classe" (idem). ${ }^{54}$

Pensamento novo em mentalidade ortodoxa carrega não poucas ambiguidades. Em sua referência à ação de porte entre "empregados agrícolas", Passos Guimarães traz à forma sindical a partir da qual começa essa "mobilização das massas do campo" alusões intercambiáveis com a ideia da superioridade proletária oriunda da noção de aliança operáriocamponesa. Uma delas aparece quando o autor diz em linguagem bem antiga que será por meio desse tipo de mediação que se montará as "correias de transmissão" que "irão ligar o proletariado e o movimento democrático das cidades aos camponeses e ao movimento democrático do campo" (idem); "correias de transmissão", como se sabe, a expressão consagrada por Stálin, referindo-se ao mundo revolucionário do seu tempo (Stálin, 1949).

Ainda nesse tópico dedicado à mediação social, o autor traz a controvérsia sobre o capitalismo agrário em desacordo com Caio Prado. Suas advertências estão dirigidas aos exageros "quer a respeito do predomínio das formas capitalistas de trabalho, quer a respeito do papel ainda absoluto das formas pré-capitalistas de trabalho". A primeira restrição

\footnotetext{
${ }^{54}$ Vale a pena aludir à rota que o PCB segue na sua evolução rumo ao sindicalismo na passagem do pior tempo da Guerra Fria aos anos 1950, deslocando-se de um ponto ao Norte para São Paulo. O MST faria depois caminho similar, vindo de um outro ponto, ao Sul, em busca daquele mesmo "coração político" de onde se expandiria pelo país.
}

se expressava no desenvolvimento dos sindicatos ainda não "muito grande", tornando-o "tarefa difícil" que não dependia "apenas da dedicação e do valor pessoal dos quadros comunistas, mas principalmente do apoio do movimento democrático, da cidade e do campo, em favor da extensão, ao meio rural, dos direitos consagrados na legislação trabalhista" (Passos Guimarães, 1960c). Com estes grifos sugerimos que ali Passos Guimarães faz referência tanto à política como dimensão da generalidade de que fala Lênin em Que fazer $?^{55}$ quanto ao caráter expansivo do sindicalismo, neste ponto concordando (parcialmente) com Caio Prado. Era difícil ignorar na discussão congressual de 1960 o tipo de associativismo no qual o historiador vinha insistindo há muitos anos.

Nessa mesma passagem de "Três frentes da luta de classes no campo Brasileiro", Alberto Passos Guimarães também apresenta o problema camponês comparando, com dados do Censo de 1950, a dimensão numérica - bem maior - da pequena agricultura em relação ao avanço das formas capitalistas de emprego. Mesmo aí o autor volta ao sentido político da mediação fazendo o contraste entre interpelação social versus subjetivismo e novamente chama a atenção para o sindicalismo que, em todo caso, então recebia estímulo do desenvolvimento (ainda lento) do capitalismo rural repete o ponto -, o avanço dos sindicatos dependendo principalmente do movimento democrático das cidades e do mundo rural (idem).

Ainda no texto ora comentado, o autor traz à "nova compreensão do problema agrário" o tema da diferenciação social. No tópico "A frente contra o latifúndio", Alberto Passos Guimarães recorre a categorias econômicas mostrando a composição segmentada da classe do "passado contemporâneo": a) aqui tínhamos um campesinato composto por extratos conforme o tipo de renda que assegurava sua dependência ao monopólio da terra; a renda-trabalho trazia o primeiro tipo de camponeses pré-capitalistas (moradores, agregados e todos os que realizavam prestação de serviço gratuito ou semigratuito); por meio da renda-produto, meeiros e parceiros; no caso dos trabalhadores sujeitos à renda-dinheiro: rendeiros, foreiros e arrendatários não autônomos ou semiautônomos; e b) por outro lado, havia

\footnotetext{
55 Como se sabe, uma das acepções de política exposta em Que fazer? diz respeito à consciência que os grupos subalternos podem adquirir em suas próprias relações com as demais classes da formação social, particularmente em suas experiências ao se relacionarem
} com a dimensão da generalidade representada no Estado. (Lênin, 1902; 1975). 
um campesinato de formação burguesa: os que possuíam domínio ou posse da terra (proprietários, arrendatários capitalistas, ocupantes e posseiros) (idem). Os protagonistas dessa frente contra o monopólio da terra seriam grupos diversos que, em comum, almejavam o desenvolvimento de relações capitalistas ("que importam em melhorar suas condições de vida"); uma massa heterogênea, em palavras do próprio Passos Guimarães, de camponeses semifeudais, camponeses pequeno-burgueses e camponeses burgueses (idem). Classe "muito recente" do "passado contemporâneo" que viria compor as reivindicações do "movimento camponês" sem que seus animadores consultassem a hierarquia que, segundo eles próprios, estruturava o processo de ativação social, vale dizer, a predominância de um grupo mais coeso e organizável viabilizando a interpelação do elemento diversificado "camponês".

Vejamos agora o sentido que predomina em "Três frentes da luta de classes no campo brasileiro", começando pelo seu ponto principal: não teríamos aqui apenas duas áreas de conflito agrário - as frentes dos camponeses contra os restos feudais e dos assalariados ou operários agrícolas contra o patronato rural, como sugeriam citações leninianas correntes no PCB. Em razão de termos uma agricultura semifeudal em periferia dependente, Alberto Passos Guimarães reivindica que também se reconhecesse ao anti-imperialismo função sobredeterminante no mundo rural. Ao terminar esse artigo com o visor da "contradição principal" (a espoliação das empresas estrangeiras no mundo produtivo agrário), o autor enfraquece a argumentação inspirada em Lênin desenvolvida em outras passagens do texto ora comentado e especialmente em "Uma falsificação e vários erros crassos na questão das etapas".

$\mathrm{O}$ encontro do tema da dependência com a abordagem atenta à particularidade de estarmos na periferia capitalista não mostra as marcas das "sedimentações passivas" que uma interseção como esta deixaria na formação social; exercício que o autor faz em relação à feudalidade, em outras passagens dos textos comentados. Dir-se-ia que há dois movimentos. De um lado, o sentido geral da "revolução nacional" leva Passos Guimarães a associar o mundo rural ao dinamismo do campo democrático; de outro, quando traz o nexo imperialismo-questão agrária não expõe incidência política como a que lhe propicia a conceituação leniniana no tema da revolução agrária "inicialmente não camponesa". Em suma, sente-se falta, no último tópico do artigo ("A frente da luta contra o imperialismo"), de referências à gênese, evolução burguesa e dependência com sentido formulativo, como em Caio Prado, ensaísta que - ao possuir interpretação de Brasil - elabora teoria própria sobre a colônia de produção, tem excursos sobre nosso industrialismo débil e chega, como vimos, a um agrarismo sindical bem preciso, pontos que o acompanha por toda sua publicística.

Embora não chegue a ser uma tematização daquele tipo, a ênfase que Passos Guimarães põe na falta de autonomia dos camponeses adquire realce quando se atenta às linhas gerais com que outros ensaístas descrevem os desvalidos rurais. Mencione-se brevemente que tivéramos aqui uma força de trabalho trazida de fora e subjugada manu militari no grande empreendimento econômico, a qual, depois da Abolição, já livre mas abandonada à própria sorte, como sublinharam Joaquim Nabuco e Gilberto Freyre, terminaria sujeita a novas formas de subordinação. Uma mão de obra mobilizada em proveito da expansão da grande lavoura mesmo tendo sido golpeada pelo fim do trabalho escravo (Alberto Passos Guimarães faz esta anotação em seu livro de 1963). Força de trabalho livre que passaria a viver, como diria Nelson Werneck Sodré, um processo de "regressão feudal", no sentido de constrangimentos recriados (Sodré, 1962). No próprio Quatro séculos de latifúndio, Alberto Passos Guimarães disserta sobre esta circunstância do pós-88. Recorrendo a Marx, especialmente ao capitulo XXV de $O$ Capital, o autor se refere ao nosso "episódio da colonização estrangeira" ao modo da "colonização sistemática" imaginada por Walkefield. ${ }^{56}$ Essa leitura da nova subordinação do trabalho livre tornase mais legível à luz da obra que Barrington Moore nos brinda sobre as vias de acesso mundo moderno, particularmente com sua descrição dos sistemas repressivos de mão de obra agrícola reintroduzidos em tempo contemporâneo, como na Alemanha. Constrangimentos esses que são realçados como ingredientes da modernização conservadora (Moore, 1983).

${ }^{56}$ Citemos a monografia de 1963: “A 'colonização sistemática' fundava-se no princípio de que as terras virgens não deviam ser postas ao alcance das populações pobres por preços baixos, a elas acessíveis, por que se assim acontecesse, os homens e mulheres mais capazes se transformariam em produtores independentes em vez de se engajarem como trabalhadores nas propriedades latifundiárias" (Passos Guimarães, 1963; 1968: 110). Em vez de terra livre ao modo do Homestead Act, aqui se inventara mecanismos que conservavam a força de trabalho sob tutela. Primeiro, a Lei de Terras (1850) se antecipara dificultando o acesso a terra por meio da posse ou da compra a baixo preço; e depois, vieram a "solução astuciosa" (sic) da parceria e as normas disciplinares da "locação de serviços" (idem:135), recriando constrangimentos pretéritos por meio de instituição "moderna". 
No último tópico de "Três frentes da luta de classes no campo brasileiro", Alberto Passos Guimarães subsume a revolução agrária não camponesa ao determinismo anti-imperialista, minimizando as qualificações com as quais lhe dera contornos particulares. Para o autor, de "natureza um tanto diversa" e de maior valor estratégico, a "contradição principal" com o elemento externo gerava uma tensão "ainda mais ampla" que as duas outras "contradições fundamentais", lembrando aqui os documentos comunistas e as Teses do V Congresso, antifeudal e anti-imperialista (PCB, 1960). Em tanto obstáculo ao desenvolvimento nacional, o autor vê na dependência a fonte de uma opressão para as massas rurais "ainda mais dolorosa" do que a opressão feudal (Passos Guimarães, 1960c). Tínhamos aqui uma circunstância distinta do sistema existente na Rússia ou no Japão do começo do século XX: a "feudalidade" brasileira recriava o caráter "dependente e semicolonial" que no século XIX marcara nossa economia agrária, permanecendo ainda muitos desses traços, passada a segunda metade do século XX. Assim se referia Alberto Passos Guimarães a tal hibridação: “... ela é uma agricultura semifeudal de tipo peculiar, baseada na monocultura de exportação, implementada e ainda mantida sob determinadas condições e determinadas limitações impostas segundo os interesses dos grupos econômicos estrangeiros" (idem). Este sistema - assim completa o autor sua referência à circunstância colonial-dependente - não seria uma "abstração" se examinado à luz da categoria econômica "ainda pouco estudada em nosso país": "o sistema do capital comprador" (idem). E dava definição ao conceito: o "conjunto de relações econômicas que atua, quer na produção, quer na distribuição dos produtos destinados ao mercado exterior. Para que as relações econômicas de tal natureza tenham existência material, eles exigem uma rede de empresas e de agentes cuja função, em última análise, é extrair processos extorsivos de coação econômica e extraeconômica, inclusive pelos processos de acumulação primitiva, a maior possível da mais valia dos camponeses trabalhadores" (idem).

Nessa passagem do texto, não advertimos uma interseção do tema do monopólio da terra com uma reorganização da força de trabalho livre que o "capital comprador" - seguindo o ponto do autor - traria a partir da sua presença em atividades modernas (firmas citadas: Bung Borg, Sambra, Anderson Cleyton, Standard Brands, entre outras). Ressalve-se, no entanto, a referência, no mesmo tópico, ao cenário modernizador que se formara na economia açucareira quando, segundo o autor, sua produção passou a se dirigir ao mercado interno e o "capital comprador" fora eliminado. Advieram então "uma série de reformas burguesas, as quais encontram sua expressão legal no estatuto da lavoura canavieira (regulamentação das relações entre produtores de cana e usineiros, entre trabalhadores do campo e fabricantes do açúcar, limitação da renda da guerra, eliminação nos contratos de trabalho de algumas formas de prestação pessoal, etc." (idem). Neste caso, diz Passos Guimarães, a "penetração do capitalismo no campo" ocorre pela via "do reformismo, da conciliação com o feudalismo, cria mercado interno à custa da miséria da população rural trabalhadora" (idem). Ou seja, trata-se de um cenário em que uma economia feudal-estamental se moderniza sob feições "reformistas" (prussianas). O realce concedido ao "capital comprador", digamos assim, tem predomínio formal sobre as demais tensões determinantes do mundo rural. Mas também há indícios de que a referência daquele texto ao "capital comprador" não expressa simples apriorismo oriundo das duas revoluções chinesas, o autor limitando-se a revestir o modelo que esboçara em "Uma falsificação e vários erros crassos na questão das etapas" e inclusive em passagens do próprio "Três frentes da luta de classes no campo brasileiro", com o anti-imperialismo que moveria a revolução nas cidades e no mundo rural. ${ }^{57}$

Essas considerações revelam desníveis na construção de Alberto Passos Guimarães. Em "Três frentes da luta de classes no campo brasileiro", o autor abre o tema do "desenvolvimento capitalista no campo brasileiro" diretamente aludindo às vias farmer e prussiana. Neste e nos outros textos, faz as menções já citadas a traços prussianos em processos evolutivos da economia açucareira e do café. Aliás, o mesmo cenário do velho mundo dos engenhos volta em Quatro séculos de latifúndio com a descrição de um verdadeiro modelo. Passos Guimarães não sugere aí um quarto "tipo ideal" de latifúndio (ao lado dos engenhos, da fazenda de gado e da fazenda cafezista, desenhados com muitas linhas na monografia de 1963) conquanto o latifúndio já estava em declínio no tempo mais

\footnotetext{
${ }^{57}$ Registre-se, de passagem, que em Quatro séculos de latifúndio (no seu capítulo dedicado à controvérsia sobre o regime econômico da Colônia), o autor alude àquele cenário, como similar ao da antiga Prússia e do sul dos Estados Unidos (sic) onde o "monopólio feudal" existira em função do mercado interno. Ao permanecer retida a totalidade do excedente dentro do país, abrira-se a oportunidade para o latifúndio "modernizar-se gradualmente", "aburguesar-se, ou converter-se em grandes propriedades capitalistas" (Passos Guimarães, 1963; 1968: 36)
} 
contemporâneo dessas transformações. Em todo caso, em torno do exemplo da cana de açúcar o ensaísta retrata traços de uma evolução capitalista que seriam comuns a outros grandes domínios. ${ }^{58}$

\section{Considerações finais}

Por fim, façamos algumas considerações sobre esse texto propriamente dissertativo. Publicado em 1963, em tempo de teste do agrarismo comunista, Quatro séculos de latifúndio escapa ao objetivo destas notas concentradas na ocasião formulativa do V Congresso do PCB.

A monografia narra a trajetória do mundo rural desde um ponto de vista bem marcante, lembrando outros ensaístas das revoluções brasileiras, como Caio Prado em A revolução brasileira (1966), Florestan Fernandes em A revolução burguesa no Brasil (1975) e em certo sentido Gilberto Freyre em Ordem e Progresso (1959), cada qual com registro característico. O que justamente distingue Passos Guimarães é o leninismo que lhe vem da militância comunista. No ensaio de 1963, o ensaísta procura mostrar o papel renovador do campesinato em sentido construtivo, como Caio Prado, outro intelectual comunista que pressupõe o desenrolar "normal" dos acontecimentos no pré-64. Em Quatro séculos de latifúndio, ${ }^{59}$ Passos Guimarães confere centralidade à reforma agrária redistribuitivista por meio de uma dissertação sobre a gênese, a consolidação e o debilitamento e crises

\footnotetext{
${ }^{58}$ Em Quatro séculos de latifúndio, estes são os pontos com os quais o autor compõe tal modelo: 1) "Extrema concentração fundiária, baseada na associação do monopólio da terra ao monopólio da indústria de transformação ou do beneficiamento da matéria-prima agrícola"; 2) "A extrema fragmentação minifundiária das piores terras, por meio da qual os latifundiários fixam, nas suas adjacências, as reservas de mão de obra para atender as suas necessidades eventuais"; 3) "O abandono das lavouras latifundiárias e sua substituição, em larga escala, pela pecuária extensiva"; 4) "A introdução, ainda em ritmo lento e em proporções limitadas mas em escala crescente, de técnicas mais adiantadas de preparo e cultivo do solo, inclusive por meios químicos e mecânicos"; e 5) "A substituição, embora lenta, das formas pré-capitalistas de renda por formas semicapitalistas ou capitalistas; e a generalização, acelerada nos últimos anos, do salariado quase-capitalista ou capitalista." (Passos Guimarães, 1963;1968: 183-192).

${ }^{59}$ No acréscimo à segunda edição de Quatro séculos de latifúndio (1968), no novo capítulo 11 ("Depois de 1964"), Passos Guimarães continua se recusando a ver no avanço do capitalismo rural o esgotamento da reforma agrária. Inclusive procura ainda desqualificar as diretrizes e as ações modernizadoras do regime militar (Passos Guimarães, 1963; 1968).
}

dos grandes domínios; processo largo durante o qual também se firmaria o protagonismo camponês.

Lembrando o Manifesto do partido comunista, a monografia apresenta nosso mundo rural na sua trajetória de mundo polarizado por configurações antagônicas: de um lado, o sistema latifundiário e, de outro, os seus "intrusos e posseiros" dos séculos iniciais e a propriedade agrária capitalista, em época contemporânea. Invasores antigos e terceiro elemento que irão dar lugar às figuras da pequena e media propriedades. Renitentes, já os primeiros grupos de camponeses constituem, para Alberto Passos Guimarães, um "elemento dinâmico" renovador, cujas vicissitudes ainda estão aí na chamada agricultura familiar ao lado dos novos e pujantes grandes domínios de um mundo rural complexo e bem diferente destes nossos dias.

Para o interesse destas notas, realcemos que Quatro séculos de latifúndio reforça o agrarismo aprovado no V Congresso. Façamos um rápido apanhado do sentido de algumas passagens do livro: a) quando disserta sobre os primeiros três séculos, o autor deixa bem visível a marca da violência nos desvalidos que sobrevivem às margens da grande propriedade sob o império do “"governo' sobre as coisas e as pessoas" (noção extraída dos senhorios açucareiros vistos como o primeiro tipo-ideal da monografia); b) nas passagens relativas às brechas que se abrem à pequena propriedade, no século XIX, quando aquele sistema autocrático se fissura; processo já importante no primeiro ciclo imigratório e que adquire envergadura e estabilidade à sequiência da Abolição com a arregimentação dos "braços livres" para a grande lavoura sob novo ímpeto burguês e c) nas referências à época das crises cada vez mais crônicas que levam o sistema agrário à decomposição (este é um ponto importante dos capítulos de Quatro séculos de latifúndio referentes aos tempos do Império e inícios da República). No século XX, sobremaneira passada sua segunda metade, o autor alude a uma época de luta de classes diversificada que enseja um novo tipo de ação camponesa. Os grupos sociais se movem nas Ligas Camponesas e em suas articulações urbanas, movimentam-se largamente por meio dos sindicatos rurais. A "classe do passado" revela-se "elemento dinâmico" na reforma do mundo rural, quer pela importância que adquire a cada dia o seu "movimento social" - reivindicativo segundo Caio Prado e "movimento camponês", misto, como o chamam Alberto Passos Guimarães e outros, quer pela colocação da reforma agrária na vida nacional como um dos seus grandes temas. 
Em Quatro séculos de latifúndio Alberto Passos Guimarães releva tanto a debilidade da "classe mais numerosa da nação" como the vê possibilidades de crescimento conforme seus mediadores aproveitem as oportunidades políticas do contexto de declínio do latifúndio e de crescente democratização do país. Contexto que se afirma à medida que o mundo político se diversifica potenciando nas mediações existentes - eleições, partidos, associativismos e opinião pública - posturas que abrem caminho, inclusive na esfera de governo (incentivo à sindicalização, Estatuto do Trabalhador Rural, a desapropriação às margens das rodovias federais, etc.). A narrativa de Passos Guimarães não antevê uma relação entre economia e sociedade - pré-determinada por razões doutrinárias - de estímulo natural à organização camponesa. A afirmação de um terreno no qual a luta de classes cada vez mais tivesse curso livre exigia a ação consciente e política dos protagonistas. Não constitui acaso que para resgatar o papel dos camponeses na história brasileira, Alberto Passos Guimarães sublinhe a pouca autonomia dos agrários, referindo-se "à necessidade da quebra do 'governo' sobre as coisas e as pessoas" e sua associação com o chamado campo democrático reformista da época.

Mesmo que em seus textos congressuais não tenha como principal visor a hipótese prussiana, Passos Guimarães exibe a questão agrária em uma circunstância particularizada por qualificações que reaparecem na monografia: a) quando nos capítulos dedicados à época colonial o autor disserta sobre a "civilização portuguesa" que aqui não constrói o novo a partir do traço mais moderno - à época, o mercantilismo - mas viria sedimentar, com instituições pretéritas, a grande propriedade em moldes estamentais. É em tal mundo que os desvalidos rurais emergem, numa relação invertida, comparada nossa circunstância com a via clássica dos enclousures: os camponeses brasileiros surgem, depois de constituído o grande domínio territorial, sob condições de subordinação e tutela profundamente arraigadas; e b) quando disserta sobre o período contemporâneo, o autor mostra um mundo agrário marcado por crises; com o passar dos tempos, mais enfraquecido e diferenciado (estes temas do debilitamento, fratura nos de cima e diferenciação social percorrem o volume conformando contexto político progressivamente favorável à movimentação dos desvalidos). Embora tal mundo rural, sem ter o fechamento dos antigos grandes domínios, continue recriando constrangimentos tanto ao trabalho quanto ao ambiente político-cultural em que vive um cidadão rural livre há mais de um século.

Salvo revisão mais cuidadosa, dir-se-ia que Alberto Passos Guimarães não perpassa as dimensões do "movimento camponês" com a abertura que lhe propicia a hipótese prussiana, daí extraindo todas suas consequências. Quando enfatiza o monopólio da terra e os "restos" que este arrasta do pretérito, o autor está próximo do conceito leniniano, mas não se pode desprezar que é com a noção do "capital comprador" que Alberto Passos Guimarães hierarquiza as determinações do mundo rural. É visível seu empenho em pôr em primeiro plano o "fator nacional no campo", em um certo sentido lembrando a José de Souza Martins. ${ }^{60}$ Em busca do protagonismo camponês, Martins, digamos, correndo o risco da simplificação, estrutura toda, ou quase toda, sua construção - também mobiliza de modo importante os temas das temporalidades coetâneas (Henri Lefebvre) e da cultura - na relação capital-trabalho (como Marx apresenta o tema no famoso livro, volume primeiro). Como consequência do processo de sua territorialização, o capital descrito por Marx passa a subsumir, no tempo mais contemporâneo, cada vez mais importantes dimensões do mundo rural brasileiro. Embora o sociólogo procure decifrar o sistema produtivo agrário com um suporte (academicamente elaborado) que em larga medida o diferencia do comunista, ambos autores - neste ponto em que Alberto Passos Guimarães recorre ao "capital comprador" - compartilham uma busca campesinista tendo por pano de fundo forte recurso a categorias abstratas. Martins amplia aquela sua referência a Marx associando o anticapitalismo camponês ao nexo capital-renda da terra (recoberto pelo registro da história lenta e o tema da cultura popular-familística). Por sua vez, na sua referência ao "capital comprador" Passos Guimarães como que abstrai a ideia de revolução na periferia capitalista com que pensara o início não camponês da revolução agrária, deixando subentendido estarmos numa circunstância colonial stricto sensu. Embora, doutra parte, tenha sublinhado no tema camponês a dimensão da política entendida nos termos da diretriz da "frente única permanente" do seu partido.

${ }^{60}$ Em outra oportunidade - quando compararmos o campo comunista com a matriz alternativa que enseja a interpelação camponesa mais contemporânea -, voltaremos àquela ideia da proximidade entre autores tão diferentes. Quatro séculos de latifúndio (1963) e Os camponeses e a política no Brasil, no seu primeiro ensaio (Martins, 1980; 1981) são textos que se singularizam por um grande empenho em valorizar o protagonismo camponês. 
Como ocorre com Caio Prado, autor comunista que exibe várias aporias, a argumentação de Alberto Passos Guimarães carrega ambiguidades não poucas vezes revestidas de muita doutrina. Do mesmo modo que a indagação sobre as variações advertidas em textos de outros clássicos desperta curiosidade, como é o caso do redimensionamento do paradigma revolucionário em um acadêmico rigoroso como Florestan no livro de 1975, perquirir a respeito de certas passagens da publicística de Alberto Passos Guimarães tem interesse pois permite avaliar até que ponto elas enfraquecem pontos seminais de um autor que buscou uma variante brasileira de "revolução nacional" em meio a fortes modelos marxistaleninistas nos quais o seu PCB vivia imerso.

\section{Referências bibliográficas}

CHAVES NETO, Elias. Política de união nacional. Revista Brasiliense, n. 1, São Paulo, setembro-outubro de 1955. 1977.

Minha vida e as lutas do meu tempo. São Paulo: Alfa-Omega,

COELHO, Marco Antonio (Assis Tavares). A tática das soluções positivas. Novos Rumos, São Paulo, 19 de julho a 4 de agosto de 1960.

ENGELS, F. Crítica al programa de Erfurt (1891), Madri: Anagrama, 1973.

. Introdução a As lutas de classe na França de 1848 a 1850 (1895). In: C. Marx e F. Engels, Obras escojidas. Moscou: 1977.

O problema camponês na Franca e na Alemanha (1894). In: $A$ questão agrária, São Paulo: Brasiliense, 1981.

FREYRE, Gilberto. Ordem e progresso. Rio de Janeiro: José Olympio Editor, 1959.

KONDER, Leandro. A democracia e os comunistas no Brasil. São Paulo: Graal, 1980.

LÊNIN, W. I. Qué hacer. (1902). In: Obras escojidas en doze volumes, v. 1, Moscou: Editorial Progreso, 1975.
Dos tácticas de la social-democracia rusa (1905). In: Obras escojidas en doze volumes, v. 1, Moscou: Editorial Progreso, 1975.

El programa agrário de la socialdemocracia rusa (1907). In: Moscou: Editorial Lenguas Extranjeras, 1949.

MARÇAL Brandão, Gildo. Partido comunista, capitalismo e democracia, São Paulo: USP, 1992. Tese.

MARTINS, José de Souza. Os camponeses e a política no Brasil. Petrópolis: Vozes, 1981

MOORE JR., Barrington. As origens sociais da ditadura e da democracia. Senhores e camponeses na construção do mundo moderno. Lisboa: Martins Fontes, 1983.

PASSOS GUIMARÃES, Alberto. A questão das etapas da revolução brasileira. Novos Rumos, Rio de Janeiro, 8 a 14 de julho de 1960a.

Uma falsificação e vários erros crassos na questão das etapas. Novos Rumos, Rio de Janeiro, 22 a 28 de julho de 1960b.

As três frentes da luta de classes no campo brasileiro. Novos Rumos, Rio de Janeiro, 28 de julho a 4 de agosto de 1960c.

Quatro séculos de latifúndio (1ª . ed., 1963). Rio de Janeiro: Paz e Terra, 1968. PCB. Declaração sobre a política do PCB (março de 1958). In: Carone: $O P C B$, vol. II, São Paulo: Difel, 1982. 1960

Teses para o V Congresso do PCB, Rio de Janeiro, folheto,

Informe de balanço do comitê central ao VI congresso do PCB (1967a). In: Vinte anos de política. Documentos. São Paulo: Lech, 1980.

PRADO JR., Caio. Formação do Brasil contemporâneo. São Paulo: Livraria Martins Fontes, 1942.

História econômica do Brasil. São Paulo: Brasiliense, 1945.

Os fundamentos econômicos da revolução brasileira. A classe operária, São Paulo, 1947.

A revolução brasileira. São Paulo: Brasiliense, 1966. 
RIBEIRO, Ivan. A agricultura e o capitalismo no Brasil (1975). Originariamente em Études Brasiliennes (Paris, s/d). In: Presença, n. 11, Rio de Janeiro, 1988.

SANTOS, Raimundo. Questão agrária e política: autores pecebista, Seropédica: EDUR, 1996.

Política e agrarismo sindical no PCB, Brasília: Fundação Astrojildo Pereira, 2002.

SODRÉ, Nelson Werneck. Formação histórica do Brasil. São Paulo: Brasiliense, 1962

STALIN, José. Cuestiones del leninismo. Moscou: eds. Lenguas Estranjeras, 1949.

VIANNA. Luiz Werneck. Liberalismo e sindicato no Brasil. Rio de Janeiro: Paz e Terra, 1976.

. Sobre a tática e a estratégia das Teses. Voz da Unidade, Debate n. 89, São Paulo, 1981.

VÁSQUEZ, Adolfo Sánchez. Ciencia y revolución (el marxismo de Althusser). Madrid: Alianza Editorial, 1978.

\section{IVAN RIBEIRO \\ Via Prussiana, Democracia Política e Reforma Agrária ${ }^{61}$}

Ao reler ultimamente textos do campo intelectual Caio Prado Jr. PCB, temos realçado elementos discursivos que estimularam os comunistas a afirmar no país uma interpelação camponesa de tipo sindical. A Declaração de Março de 1958 já associara a reorientação na "tática agrária" comunista ao impulso que o associativismo começou a ter no mundo rural desde os inícios da década de 1950. Dois anos depois, no seu V Congresso, o PCB converteu sua experiência de "atuar nos sindicatos" - a diretriz com que abandonara o velho paralelismo sindical - na nova mediação dos grupos agrários: "A fim de impulsionar a organização das massas no campo, é necessário atribuir atenção primordial aos assalariados e semiassalariados agrícolas. Em virtude da sua condição social de proletários ou semiproletários, como também do seu grau de concentração, os assalariados rurais são mais suscetíveis de organizarem-se em sindicatos que podem constituir as bases iniciais para a mobilização das massas camponesas" (PCB, 1960: 72).

Esse tipo de atuação agrária não se deve apenas ao faro político e ao pragmatismo dos comunistas como também recebe certa influência de Caio Prado e tem em Alberto Passos Guimarães sua mais clara formulação. No entanto, se, por um lado, o argumento desenvolvido por Alberto Passos Guimarães lastreia a nova mediação camponesa, por outro, não tematiza a questão democrática no sentido do comentário que Sodré acrescentara ao seu livro de 1962. Com efeito, quase ao final de Formação histórica do Brasil, lê-se: "A defesa do regime democrático, no processo da revolução brasileira, não se prende, assim, ao supersticioso respeito a uma legalidade qualquer, mas na compreensão de que a democracia é o caminho apropriado ao seu desenvolvimento. Não interessa ao nosso povo, evidentemente, uma legalidade qualquer, mas o regime democrático efetivo cujo conteúdo esteja intimamente ligado ao desenvolvimento de alterações econômicas, políticas e sociais capazes de afetar profundamente o país e corresponder ao avanço

${ }^{61}$ Este registro sobre Ivan Ribeiro compõe o texto "Venturas e desventuras da revolução agrária no Brasil" (Relatório parcial da pesquisa "Pensamento social e agrarismo no Brasil, CPDA/ UFRRJ/Nead). Uma versão do mesmo foi publicado, sob o título "O agrarismo inconcluso de Ivan Ribeiro", na revista Estudos Sociedade e Agricultura v. 14, n. 1, abril de 2006. 
das forças produtivas que impõem modificações radicais nas relações de produção" (Sodré, 1962: 404). (Os grifos são do autor destas notas).

No entanto, no contexto formulativo da passagem da década de 1950 aos anos sessenta, não se desenvolvera na publicística pecebista o tema da associação do agrário com a questão do formato do político, usando agora expressão de uma outra época (cf. Vianna, 1976). A passagem do livro de Sodré onde aparece alusão ao modo prussiano de nossa modernização é esta: "No campo, assim, de um lado estão os latifundiários ou latifundiáriocapitalistas; de outro, a grande massa de arrendatários pobres, o semiproletariado e o proletariado rural, toda a massa de camponeses pobres, ao lado dos camponeses médios e da burguesia rural, em luta pela posse da terra, mas sempre empurrada para engrossar o proletariado rural. As contradições entre as forças produtivas e as relações de produção chegaram a um ponto crucial. Elas nos fornecem a caracterização, do Brasil, segundo um estudioso, de um desenvolvimento à moda prussiana, sob a ação e a influência do imperialismo. Avança sem dúvida a penetração capitalista, mas os restos feudais vão sendo conservados e o monopólio da terra zelosamente defendido" (idem: 357).

Essa é a linhagem da qual descende Ivan Ribeiro. A ela Ribeiro incorpora circunstâncias discursivas que vivera intensamente durante quase duas décadas (1969-1987). Os primeiros dez anos correspondem ao tempo de um Brasil modernizado pela ditadura de 1964, que, nos anos de chumbo e na época dos exílios, levaria Ivan Ribeiro ao exterior. Também lhe resultou proveitoso ter conhecido o socialismo real na Polonia e vivido a via eleitoral ao socialismo no Chile de Salvador Allende. Ainda foi muito estimulante para Ivan Ribeiro sua passagem pela Itália, antes de retornar ao Brasil, no tempo do PCI de Berlinguer e do "compromisso histórico". Esta última experiência consolidou seu vínculo com a obra de Gramsci, autor da sua preferência, conhecido no convívio com velhos e jovens intelectuais do seu PCB, partido ao qual se manteve intelectualmente ligado até morrer, em 8 de setembro de 1987, no acidente de avião que vitimou o ministro Marcos Freire e membros da sua equipe, da qual Ribeiro fazia parte.

$\mathrm{Na}$ sua militância, essas circunstâncias se cruzariam no que poderíamos chamar - em referência ao debate que antecedeu a Declaração de Março - de segunda renovação pecebista (Santos, 1992; 1994). Ele integrou uma corrente que, ainda no exílio, desde 1975, procuraria uma convergência - buscando uma segunda "nova política" - entre o sentido da tática de frente democrática, de construção progressiva e capaz de resistir, isolar e, afinal, derrotar a ditadura, arduamente defendida pelo PCB, e o renovamento do marxismo político brasileiro tentado por outros intelectuais da sua geração naqueles tempos eurocomunistas.

Como se sabe, derrotada essa corrente no interior do PCB, no VII Congresso de 1982-83, alguns deles lançaram a revista Presença, que circularia por todo o decênio subsequente. Pode-se encontrar registro público dessa última fase militante de Ivan Ribeiro em artigos seus publicados no Jornal da República, que circulou em São Paulo durante o ano de 1979, no qual Leandro Konder escrevia - e para onde levou companheiros seus daquele grupo intelectual pecebista. Há textos de Ivan Ribeiro no semanário comunista Voz da Unidade publicados em 1981 e depois na revista Presença, da qual, aliás, ele próprio era um dos principais animadores, junto com Luiz Werneck Vianna, Carlos Nelson Coutinho e Leandro Konder.

\section{Um novo clima intelectual no campo pecebista}

A menção ao prussianismo e às modalidades farmer e alemã de evolução agrária já não era nova no $\mathrm{PCB}$, tendo circulado nos debates do $\mathrm{V}$ Congresso do PCB de 1960. Todavia, essas categorias produziriam outros resultados no PCB quando, na ensaística da corrente anteriormente citada, passou-se a realçar justamente a associação que - em sua reflexão sobre a revolução burguesa não clássica - Lênin fazia entre o problema agrário e a forma do político. A hipótese prussiana tem novo aproveitamento quando os citados jovens publicistas brasileiros tentaram apreender aquele tipo de associação numa experiência de capitalismo tardio e dependente, procurando trazer esta problematização para a práxis política de esquerda.

Como dizia um deles, aqui não tivemos um curso burguês clássico, tendo o país conhecido uma "estruturação prussiana", cuja singularidade "estaria no fato do setor agrário mais desenvolvido em termos capitalistas o agroexportador - ter sido desalojado do poder pelo menos desenvolvido" (Viana, 1976). ${ }^{62} \mathrm{E}$ ainda: "Na situação do campo brasileiro, a ausência de

${ }^{62} \mathrm{O}$ argumento prosseguia: "Isso se explica, como vimos, pela impossibilidade daquele setor em dirigir o processo de modernização dado o seu isolamento real e incontornável das 
um campesinato dinâmico, resultante da sua falta de vínculo com a sociedade mercantil, barraria um processo de transformações agrárias 'à americana'. Basicamente, a questão se resolvera pela assunção de papéis capitalistas pelo grande proprietário de terras, exportador ou não". (Idem: 133). O país se modernizara sob os auspícios da política, a burguesia crescera e expandira o seu domínio sem postular hegemonia social e política, sempre amparada pelo Estado, "fazendo dele seu partido político real". Ao manter sua aliança com as oligarquias agrárias atrasadas e ao ter se realizado como classe sem haver dirigido um processo revolucionário, aquela burguesia se tornava incapaz de liderar a democratização da sociedade (Vianna, op. cit.).

Em relação ao tempo contemporâneo, a referida ensaística chamava a atenção para o caráter não recessivo do novo regime que emergira da derrubada de Goulart e modernizara de modo conservador tanto a economia como a própria agropecuária (Vianna, 1983; Coutinho, 1986). Argumentava-se nessa literatura pecebista que, na circunstância do pós-64, o dado estratégico viria a ser a relação entre o intenso crescimento das forças produtivas nacionais e a natureza da transição democrática em pleno curso no final da década de 1970, sob impulso da lógica econômica modernizante mas dependente do oportuno desempenho dos atores políticos (Vianna, 1983).

Nessa construção tornava-se crucial o tema da complementaridade entre "transição política" e "revolução", trazendo-se até nós a bibliografia que realçava o caso daqueles países que haviam se modernizado tardiamente por vias autoritárias, sem ter criado uma institucionalidade política adequada (idem). As experiências de lá e a de cá sugeriam que, à hora do colapso dos seus regimes autoritários, poder-se-ia formar aqui uma situação na qual a democratização política do país, então cada vez mais em rápido andamento, não só viria concluir o período ditatorial como também poderia trazer - dizia outro daqueles intelectuais - "consequências progressistas de efeito quase revolucionário” (Konder, 1984).

demais classes, camadas e estratos sociais em emergência na sociedade civil. Mas o domínio do aparelho do Estado por parte dessa elite 'atrasada' no econômico lhe vai facultar um percurso extremamente rápido no sentido da adoção de novos papéis econômicos, como o do empresário agrícola, do industrial ou do financista" (idem: 139).
No plano da "formulação da política", esse clima intelectual representou, no $\mathrm{PCB}$, um novo passo a redimensionar a proposição da Declaração de Março, a qual já em 1958 havia rompido com o viés estagnacionista, passando a associar ao crescimento econômico um processo de complexificação social e a tendência do país à democratização política. Ao comparar a nossa via de modernização com o modelo clássico de revolução burguesa, aquela ensaística advertia que, aqui, a relação entre economia e política obedecia a uma lógica de natureza "muito mais irregular", também se podendo imaginar nossa modernização burguesa como uma "revolução passiva".

Essa qualificação, sobremaneira após se apreender a nova circunstância do pós-64 como uma contrarrevolução modernizadora, ${ }^{63}$ levava a se ter uma ideia de mudança social diferenciada do antigo axioma atraso/revolução. Daí se tendia a conceber o processo mudancista como uma gramsciana "guerra de posições", no dizer de Carlos Nelson Coutinho; ou, ainda, como um processo de transformações duradouras que assumiria forma de "reformismo forte" à medida que a democratização política, intensa desde a anistia de 1979, se aprofundasse cada vez mais.

Assim ampliado a partir de meados da década de 1970, esse marxismo político implicaria um outro modo de colocar o problema agrário, como se pode ver justamente na ensaística de Ivan Ribeiro, publicista que justamente emerge, na acima chamada segunda renovação pecebista, como autor especializado no tema rural. Em vez de limitar-se à centralidade da aliança operário-camponesa, continuando o modelo marxista e leninista de revolução, a nova leitura da questão agrária - e rural - viria conceder cada vez mais importância estratégica à relação entre a democratização social e o enraizamento progressivo da democracia política em toda a formação social; uma relação que só se assentaria com o concurso do campo da política.

A nova percepção seguiria a trilha aberta por Caio Prado Jr. com sua insistência no sindicalismo generalizável no território e Alberto Passos Guimarães, autor que condicionava o tema camponês à política geral de ${ }^{63}$ Carlos Nelson Coutinho relembra o conceito de "fascismo pelo alto" de Barrington Moore
para referir-se ao que ele chama de "paradoxo aparente" de um regime
"contrarrevolucionário" que, como no caso do Japão pré-bélico do exemplo de Moore, aqui
também se colocava à frente de um processo de intensificação do desenvolvimento das forças produtivas (Coutinho, 1986). 
frente única. Afastando-se da sociologia clássica das revoluções, a nova percepção iria sugerir que os camponeses fossem interpelados como uma questão relativa à condição de exclusão da "maioria da população" (no sentido do autor desta última expressão, Caio Prado Jr.) e, agora decididamente, sob o ponto de vista da "generalidade da política". Vale dizer, como grupos que, ao invés de objeto de instrumentalização a serviço de operações de poder - mesmo que chamados para projetos emancipatórios futuros -, deviam ser vistos como contingentes a se incorporar à economia realmente existente no país, à vida nacional, em particular ao seu sistema político democratizado.

Ivan Ribeiro não chegou a consolidar propriamente um constructo agrarista, mas deixou sugestões para uma visão renovada da reforma do mundo rural brasileiro em moldes democrático-institucionais. Seu recurso à via prussiana tem esse sentido ao fazer parte do contexto discursivo em que o conceito voltava a circular no PCB. No grupo intelectual a que pertencia Ribeiro a noção de via prussiana era relançada tanto para servir como cânone de interpretação do nosso capitalismo quanto como cânone de análise política. Neste caso, como um recurso útil para divisar com maior definição a problemática geral posta aos comunistas naquela fase final do PCB: a democratização da vida nacional requerida pelo padrão histórico da modernização "pelo alto" como uma transformação de caráter prolongado (falava-se naqueles tempos da anistia de 1979 em reversão do prussianismo). Este era o tema em torno do qual, na época, discutia-se o caminho democrático brasileiro ao socialismo.

\section{Uma reforma agrária sob procedimentos democráticos}

Em vez de ver na modernização da agropecuária brasileira o cancelamento da reforma agrária, Ivan Ribeiro vai mostrar que a nova circunstância redimensionava o problema agrário e exigia outro tipo de reformismo. Diversamente de Caio Prado Jr. e Alberto Passos Guimarães que, mesmo no pós-64, mantiveram suas reservas ante o crescimento do nosso capitalismo, Ribeiro não se fecharia ante o tema da modernização, mas daria um passo a mais na consolidação da ideia de reforma agrária "ampliada". Para este conceito já apontavam alguns autores, como o próprio Caio Prado Jr. e particularmente Ignácio Rangel. Com argumentos diversos, os clássicos sugeriam um reformismo que ao problema fundiário combinasse outras dimensões da questão agrária e rural, como a legislação social, no caso do historiador comunista; ou os problemas "impropriamente agrários", como propunha Rangel em 1962, atento à associação entre reforma agrária e excedente populacional. ${ }^{64}$

Ivan Ribeiro expõe o seu argumento no texto "A agricultura e o capitalismo no Brasil", publicado originariamente em 1975, com o pseudônimo de Cláudio Barros, na revista Études Brasiliennes, editada pelo PCB em Paris na época de exílio dos anos de chumbo. Ribeiro procurava mostrar que a agricultura brasileira já deixara de ser o lócus dos setores mais atrasados da economia, modernizada por um capitalismo agrário sob a égide da grande propriedade. Ao modo prussiano, um conjunto de transformações foi adaptando nossa agricultura, substituindo procedimentos "feudais" por procedimentos burgueses, constituindo um mundo onde "misérias modernas" coexistiam com "misérias antigas" (Ribeiro, 1975; 1988). ${ }^{65}$ Ao recorrer à chave do prussianismo, Ribeiro tanto reconstruía teses do seu próprio partido, que ainda alimentavam a ideia de reforma agrária antifeudal e antilatifundiária, como interpelava visões que convocavam ações camponesas dissidentes da ordem institucional e que ainda naqueles anos resistiam em aceitar o reformismo agrário brasileiro. Um reformismo que, há décadas, passara a tematizar constrangimentos de tipo sistêmico (há muito tempo, era tema seu a incorporação dos camponeses à economia realmente existente no país) e a valorizar as possibilidades de ampliação da cidadania no mundo rural. Aliás, como defendiam, desde os anos 1950, o Iseb, o próprio PCB e áreas de grandes partidos, como o PTB de Jango; e, depois de 1964, não

\footnotetext{
${ }^{64}$ As razões de Caio Prado Jr. advinham da sua teoria sobre a natureza da formação social; no caso do argumento de Rangel, a concentração nos aspectos "impropriamente agrários" (problemas agrícolas, relativos a produção e preços, especialmente os canais de intermediação, cf. Silva, 1996; 1998) devia-se à inexistência no pré-64 de condições políticas para um vasto processo expropriatório. José Graziano da Silva, na época do primeiro governo de Fernando Henrique, retomaria aquela conexão de Rangel para propor uma nova reforma agrária "não essencialmente agrícola", ampliando o conceito (“... é preciso criar novas formas de ocupação para uma parte significativa da população brasileira que não tem qualquer qualificação profissional que os habilite a procurar outra forma de inserção produtiva no novo mundo do trabalho que se delineia já para este final de século", cf. Silva, op. cit.: 82).

${ }^{65}$ Ribeiro faz sua aquela conhecida expressão de Marx, também citada por H. K. Takahashi, economista japonês com quem, no seu ensaio, Ribeiro dialogava a propósito do tema da via prussiana na transição do feudalismo ao capitalismo (idem).
} 
poucos ambientes de extração pluriclassista que convergiam na resistência democrática ao regime militar.

Sem alimentar nenhuma forma de campesinismo reativo à modernização, Ivan Ribeiro destacava da sua leitura do mundo rural que emergia na década de 1970 os grandes setores da agricultura, em que, dizia ele, não se justificava o parcelamento da propriedade e a criação de uma economia camponesa e em que se deveria trabalhar para a ampliação e melhora das condições de trabalho, universalizar a legislação trabalhista e enraizar um largo e diversificado associativismo (Ribeiro, op. cit.), nisso recordando Caio Prado Jr. O que não implicava menosprezar a economia familiar camponesa, à qual, por não ser ainda completamente capitalista, Ribeiro achava que um processo de reforma agrária farmer poderia trazer grandes benefícios e representar avanço considerável para vastos contingentes sociais (idem). Ademais, Ivan Ribeiro se mantinha atento ao processo da "modernização excludente" que provocava a diferenciação "para baixo", com a dissolução das pequenas propriedades e a transformação dos camponeses sem trabalhadores volantes e assalariados nos pequenos centros urbanos regionais, num contexto de fragmentação social; processo que logo seria investigado pela bibliografia especializada daquele começo da década de 1980. Ele percebia ainda que se os camponeses perdiam a sua definição econômico-revolucionária e que "eles" adquiriam nos (ou em interação com os) grupos sucedâneos um protagonismo novo, gerando outros tipos de processos sociopolíticos que convergiam com a secularização que a expansão da mídia provocava no mundo rural erodindo a ordem de mando oligárquica da sociedade agrária (Ribeiro, 1983). Em suma, neste registro de Ivan Ribeiro, que permanecerá inconcluso no campo comunista, o destino do mundo rural era visto - sob olhar inspirado na melhor tradição marxista - como capaz de renovar-se em moldes modernos. Ao contrário de alimentar a ideia de que a modernização só lhe traria catástrofes, essa ensaística ensejava a ideia de que o mundo rural não tinha porque não se conciliar com a esfera econômico-social, com a democracia política e a cultura, como as cidades vinham fazendo há muitíssimo tempo, não obstante as patologias que mais e mais se acumulavam em amplas franjas do seu mundo ao mesmo tempo modernista e devastado por novas mazelas.

Com atualizada percepção de renovamento do país, Ivan Ribeiro redimensionava sua tradição, como, por exemplo, quanto ao conceito de democracia, compreendida, em relação ao mundo rural, de modo ambíguo, mais como incorporação econômico-social dos camponeses. Em sua ideia de reforma agrária "ampliada", concebida no contexto de nossa modernização "pelo alto", Ribeiro não realçava apenas as esferas da inclusão social e da revitalização econômica, mas sublinhava uma dimensão de enlace do mundo rural com a questão democrática em geral. Dir-se-ia que, neste ponto, o autor buscava um enfoque alternativo que deslocasse a problemática da reforma agrária do "estrutural" para o âmbito do “institucional”. Ou seja, Ribeiro não só mobilizava sua tradição - à qual, desde meados dos anos 1950, procurava equacionar politicamente o tema agrário - como pretendia apontar processos que tornariam possível aos camponeses e trabalhadores rurais "entrar no jogo político enquanto força de classe e individualidade" (idem); vale dizer, levá-los para dentro de um sistema político democratizado.

As outras circunstâncias vividas pelo publicista também deixaram traços na sua passagem pela academia brasileira. Primeiramente se juntou ao grupo de pesquisadores que se havia reunido, em meados dos anos 1970, em torno do tema agrário no centro acadêmico da FGV conhecido como a pós-graduação do Horto Florestal ou CPDA (Curso de Pós-graduação em Desenvolvimento e Agricultura). Ele também esteve na transferência do mesmo CPDA para a Universidade Rural, em 1984, onde, juntamente com outros professores militou na política universitária ativando - inclusive como candidato - as movimentações das primeiras eleições diretas para Reitor. Não é um acaso que a vivência no socialismo real e no Chile de Allende se faça presente nos textos que Ribeiro escreveu sobre o tema rural, ajudando-o a problematizar uma das questões da sua preocupação acadêmica: a agricultura familiar. Este tema, segundo ele, era ainda pouco estudado no Brasil da segunda metade dos anos 1970. Da vivência no socialismo da Polônia e do diálogo com o economista polonês Jerzi Tepicht, Ivan Ribeiro trouxe a questão da persistência da pequena produção familiar nos processos de reestruturação da agricultura. Questão que igualmente veio da via chilena ao socialismo, experimento conturbado por condutas equivocadas quanto à expropriação das pequenas e médias unidades produtivas. Pode-se dizer que ambas experiências instigaram Ribeiro a realçar o tema da função dos pequenos produtores na reforma do mundo rural brasileiro. 
A propósito disso, recorde-se que, em um de seus artigos publicados no Jornal da República, de 1979, Leandro Konder chama a atenção para o fato de que, dentre os autores que àquela época mobilizavam o conceito leniniano de via prussiana, já estava Ivan Ribeiro, por conta do seu texto chamado "A importância da exploração familiar camponesa na América Latina", que fora publicado na revista de São Paulo Temas de Ciências Humanas, em 1978 (Konder, 1979; 1980).

Com efeito, nesse ensaio há a postulação apontada por Konder: "As particularidades da América Latina - diz Ribeiro em 1977 - adquirem maior nitidez quando observamos a circunstância de que, no Continente, a evolução do capitalismo na agricultura (com exceção do México) seguiu um caminho aproximado da via prussiana. Isso significa que os latifúndios subsistem e se convertem paulatinamente em base da exploração capitalista da terra; conservam-se, igualmente, durante décadas, seu predomínio político, a opressão, a humilhação, a miséria e a ignorância dos camponeses. Não ocorreram revoluções burguesas do tipo clássico, através das quais a grande propriedade fosse destruída radicalmente (e, com ela, os traços pré-capitalistas), abrindo-se assim caminho para o livre desenvolvimento do capitalismo com base em propriedades familiares." (Ribeiro, 1977; 1988: 162). Completemos essa passagem: "Como resultado, o que é definido na América Latina como exploração familiar camponesa resulta de um conceito mais elástico, englobando unidades produtivas cuja força de trabalho é obrigada a procurar ocupação fora dos limites de sua parcela e abrangendo arrendatários que cultivam as terras alugadas basicamente com sua mão de obra familiar. Entretanto mantém traços comuns com a economia camponesa europeia, tais como a utilização intensiva da força de trabalho no cultivo das terras e a baixa absorção de insumos industriais externos" (idem: 162-63). Naturalmente essa generalização da hipótese prussiana para o Continente depreende-se do caso brasileiro por sermos o país, como esclarecia então o próprio autor, "em que se faz sentir com mais força a versão latino-americana da via prussiana de transição ao capitalismo" (idem: 166).

O destaque dado por Ivan Ribeiro às explorações familiares camponesas não era apenas uma "concessão" a seres que estariam condenados ao desaparecimento e à socialização conforme a clássica previsão marxista, mas decorria das "significativas qualidades" que ele reconhecia na economia camponesa. ${ }^{66}$ Como registrava o autor, a valorização decorria de duas posturas: de um lado, a de não se considerar os assalariados típicos e os super-minifundistas como os únicos grupos "capazes de apoiar o processo de transformação na agricultura" e, de outro, o cuidado de evitar o menosprezo dos agricultores familiares que levava "ao estreitamente da base política necessária ao bom êxito das reformas estruturais" (idem). No entanto, esse realce nas explorações familiares camponesas não portava conotação campesinista, ou seja, não implicava "negar a substancial importância de uma ação simultânea em relação ao setor capitalista da agricultura", como ele próprio anota, retomando o argumento geral nas últimas linhas do seu ensaio (idem: 175).

Com essa trajetória, não estranha que, com o advento da Nova República, Ivan Ribeiro se licenciasse do CPDA para integrar a equipe do ministro Marcos Freire, motivado pelo que ele mesmo à época dizia ser um combate para afirmar uma linha mais reformista na área agrária do primeiro governo civil na redemocratização da segunda metade dos anos $1980 .{ }^{67}$ Ivan Ribeiro interrompeu seu labor publicista ainda jovem, deixando incompletas pesquisas acadêmicas sobre o tema rural. Sua presença, todavia, pode ser visualizada nos textos recolhidos pela coletânea organizada por Carlos Nelson Coutinho e Maria Beatriz David de Albuquerque, chamada Agricultura, Democracia e Socialismo, publicada em 1988 pela editora Paz e Terra, pouco menos de um ano após a sua morte.

\begin{abstract}
${ }^{66}$ Ribeiro enumerava: fonte de emprego e de aumento da produção com técnicas não modernas (poupando assim insumos industriais), "não podendo, porém, ser consideradas como grande potencial de acumulação de capital" (idem: 165).

${ }^{67}$ Uma semana antes do acidente de avião, encontrei-me com Ivan Ribeiro na Rodoviária de João Pessoa, ele vindo de Petrolina (PE) onde fora cumprir missão de pesquisa e eu proveniente de Campina Grande (PB) onde então residia. Ribeiro me relatou na ocasião que, devido à ambigüidade da Nova República, naquele momento estava demissionário da equipe da reforma agrária do governo. No entanto, ainda esperaria uma reunião do ministro Marcos Freire com o presidente Sarney, agendada para os próximos dias daquele mês de agosto de 1987, da qual ele esperava definição quanto aos rumos imediatos do Ministério da Reforma Agrária.
\end{abstract}




\section{Referências bibliográficas}

COUTINHO, Carlos Nelson. As categorias de Gramsci e a realidade brasileira. Presença, n. 8, ago. 1986.

KONDER, Leandro. "Via prussiana" (1979). In: Os comunistas e a democracia no Brasil. Rio de Janeiro: Graal, 1980.

O atraso é tanto que o governo Tancredo terá efeito quase revolucionário. Tribuna da Imprensa, 24 de setembro de 1984.

PCB. Declaração do Comitê Central sobre a Política do PCB (1958). In: Vinte Anos de Política. São Paulo: Lech, 1980. 1960.

Teses para discussão do V Congresso, folheto, Rio de Janeiro,

RANGEL, Ignacio. A questão agrária brasileira. Recife: Comissão de Desenvolvimento Econômico de Pernambuco, 1962.

RIBEIRO, Ivan de Otero. A agricultura e o capitalismo no Brasil (1975). In: Coutinho, Carlos Nelson e Albuquerque, Beatriz D. de (orgs.). Agricultura, democracia e socialismo. Rio de Janeiro: Paz e Terra, 1988.

. A questão agrária e a democracia. Presença, n. 8, São Paulo, nov. 1983.

A importância da exploração familiar camponesa na América Latina (1977). In: Coutinho, Carlos Nelson e Albuquerque, Beatriz D. de (orgs.). Agricultura, democracia e socialismo. Rio de Janeiro: Paz e Terra, 1988.

SANTOS, Raimundo. O pecebismo inconcluso. Escritos sobre ideias políticas. Seropédica: 1992; 1994.

Caio Prado Jr. e a cultura política brasileira. Rio de Janeiro: Mauad, 2001.

SILVA, José Graziano da. Por uma reforma agrária não essencialmente agrícola (1996). In: Santos, Raimundo e Costa, Luiz Flávio C. (orgs.). Política e reforma agrária, Rio de Janeiro: Mauad, 1998.
SODRÉ, Nelson Werneck. Formação histórica do Brasil. São Paulo: Brasiliense, 1962.

VIANNA, Luiz Werneck. Liberalismo e sindicato no Brasil. Rio de Janeiro: Paz e Terra, 1976.

O problema da cidadania na hora da transição democrática. Rio de Janeiro: Série Iuperj, 1983. 


\section{II - PARTE \\ TEXTOS SELECIONADOS}

\section{Caio Prado Jr.:}

O ESTATUTO do Trabalhador RURAL ${ }^{1}$

Foi quase de surpresa, pode-se dizer, a promulgação da lei dispondo sobre o ESTATUTO DO TRABALHADOR RURAL (Lei $\mathrm{n}^{\circ} 4.914$, de 2 de março de 1963, publicada no Diário Oficial, de 18 de março). Sabia-se que transitava no Congresso Nacional grande número de projetos relativos ao trabalhador rural. Mas não tinham notícias seguras a respeito, uma vez que as informações veiculadas pela imprensa acerca do assunto são extremamente escassas. Chamamos a atenção para o fato a fim de notar o desinteresse que cercou a elaboração do que constitui sem dúvida o mais importante acontecimento relativo às tão apregoadas reformas de base - tão apregoadas, mas tão pouco estudadas e discutidas em termos concretos e capazes de levarem a conclusões realmente práticas. A extensão da legislação social-trabalhista para o campo e a proteção legal do trabalhador rural - até hoje praticamente excluído dessa proteção que só vem favorecendo o trabalhador urbano - têm um alcance econômico e social que raros diplomas legais tiveram até hoje entre nós. Apesar das graves falhas que apresenta a lei promulgada, e que logo veremos, seus efeitos serão consideráveis, pois se efetivamente aplicada com o devido rigor, promoverá por certo uma das maiores transformações econômicas e sociais já presenciadas neste país. Será, podemos dizer, uma verdadeira complementação da lei que aboliu a escravidão em 1888. Não exagero, como se comprovará em seguida. E assim sendo, é verdadeiramente de estarrecer o desinteresse pelo Estatuto revelado durante o trânsito do projeto no Congresso, por parte das forças políticas de esquerda e progressistas. Tivessem elas atentado para a importância do assunto, e para o que ele encerra de potencialidade renovadora de nossa estrutura econômica e social agrária, e ter-se-ia alargado o debate e estudo do projeto, o que por certo evitaria as graves insuficiências em que infelizmente incide a lei

\footnotetext{
${ }^{1}$ Este artigo foi publicado ns Revista Brasiliense, n. 47, São Paulo, maio/jun. 1963
}

promulgada. Poderíamos dispor agora de um texto legal capaz de efetivamente promover e realizar, em larga escala, a transformação de nossa economia agrária. A incompreensão das forças políticas que deveriam estar à frente da tarefa, adiou esses efeitos, ou boa parte deles pelo menos, para quando a prática tiver posto em evidência as falhas da lei. E devemos notar esses fatos a fim de alertar a opinião pública, para que não se dê com o Estatuto o ocorrido com alguns benefícios que desde longa data são legalmente assegurados ao trabalhador rural, e que permanecem até hoje letra-morta, como o salário-mínimo, vigorante desde a Consolidação da Legislação Trabalhista de 1943. Há vinte anos, portanto, em que nem as autoridades administrativas, nem os tribunais, nem mesmo as organizações da classe trabalhadora, partidos e agrupamentos políticos de esquerda ou que se dizem tais, tivessem jamais denunciado essa escandalosa violação da lei, e chamado para ela a atenção das suas vítimas, os trabalhadores rurais que isolados como se encontram e sem ninguém para os aconselhar e ilustrar, ainda ignoram na maior parte os seus direitos.

A análise pormenorizada do Estatuto demandaria longo estudo a que não é possível proceder desde logo, e que não caberia mesmo nesta primeira abordagem da matéria. Procurarei apenas destacar o fundamental, a fim de mostrar como falhou o legislador que não levou em conta, em boa parte dos casos, as diferenças profundas que existem nas relações de trabalho no campo brasileiro, quando comparadas com as da indústria e comércio. O legislador se limitou em regra, e com poucas exceções, a transpor para o trabalhador rural as disposições legais que já fazem parte de nossa legislação trabalhista e foram traçadas com vistas ao trabalhador urbano. O que tornará difícil a aplicação delas a muitas situações ocorrentes no campo, e abre perspectivas para a fraude e não aplicação da lei. Em estudos que publiquei na REVISTA BRASILIENSE, particularmente nos $n^{\text {os }} .28$ (março-abril de 1960) e 43 (setembro-outubro de 1962) procurei mostrar como as relações de emprego se disfarçam muitas vezes no campo sob formas diferentes. O que dá margem para dúvidas e permitirá em muitos casos contornar a lei. No caso do trabalho urbano (indústria e comércio) o que se encontra em regra é o salariato puro, isto é, o pagamento do trabalho exclusivamente em dinheiro. A situação é assim relativamente simples, e se apresenta homogênea para todos os trabalhadores. Outro o caso na agropecuária, por força de circunstâncias próprias em que aí se realizam as atividades produtivas. As relações de trabalho e emprego assumem muitas vezes grande complexidade, pois a 
remuneração do trabalhador se faz por diferentes formas, como sejam com uma parte do produto, com o direito de ocupar com atividades próprias certas áreas da propriedade etc. Acresce a isso a diferença das situações respectivas de uma para outra atividade rural, de uma para outra região. E mesmo frequentemente de um para outro momento. As relações de trabalho no campo variam consideravelmente no tempo e no espaço, em contraste com o que se dá na indústria e no comércio. E tal variabilidade precisa naturalmente ser levada em conta pela lei, o que o Estatuto que estamos analisando reduz a um mínimo que absolutamente não reflete, e em que portanto não se preveem de maneira adequada as inúmeras situações que se apresentam e se podem eventualmente apresentar. Sob esse aspecto, o Estatuto promulgado evidencia a imaturidade do assunto e a falta de um estudo e uma discussão atentos dele.

Isso se verifica logo na definição do trabalhador rural, que para os efeitos da lei "é toda a pessoa física que presta serviços a um empregador rural, em propriedade rural ou prédio rústico, mediante salário pago em dinheiro ou in natura, ou parte in natura e parte em dinheiro" (art. $3^{\circ}$ ). Essa definição é insuficiente para compreender, de maneira a não deixar dúvidas certas categorias de trabalhadores que pela natureza real de suas relações de trabalho, são autênticos empregados, embora formalmente apresentem caráter diferente. Estão nesse caso os parceiros (meeiros, terceiros...) que embora dentro do estrito formalismo jurídico se distinguem dos "locadores de serviços" (na conceituação do Código Civil), e não sejam portanto propriamente empregados, constituem de fato, na maior e principal parte dos contratos de parceria verificados na agropecuária brasileira, legítimos empregados, e portanto com direitos idênticos a outros quaisquer empregados assalariados ou semiassalariados.

Essa questão dos parceiros agrícolas já tem sido muito discutida entre nós. Uma errônea interpretação da situação dos parceiros, muito vulgarizada nas correntes políticas de esquerda do país, considera a parceria, em particular a "meação" que é mais frequente e conhecida, como remanescentes de um suposto "feudalismo" que caracterizaria, segundo aqueles teóricos, a economia agrária brasileira. Não voltarei aqui a um ponto que já debati e desenvolvi suficientemente, a meu ver, nos estudos acima referidos insertos na REVISTA BRASILIENSE. $O$ fato é que a meação, tal como se pratica na maior e principal parte da agropecuária brasileira em que ela se verifica, não passa essencialmente de simples relação de emprego, e nada tem em comum, senão formalmente, com a "parceria" autêntica, que representa, essa sim, uma forma pré-capitalista de pagamento da renda da terra in natura, em vez de o ser em dinheiro, quando então constitui o arrendamento capitalista.

Não é essa contudo a parceria que se observa por exemplo na cultura do algodão em São Paulo e outros lugares. Aí a meação que se pratica representa simples relação de emprego, constituindo a "meia" que cabe ao trabalhador, remuneração do seu trabalho; remuneração essa assimilável por todas as razões ao salário em dinheiro. Excluído-o formalismo jurídico, e nem mesmo todo ele porque faltam nessa "parceria" de que tratamos muitos caracteres inerentes ao legítimo contrato de parceria, temos na realidade e de fato uma relação de empregado para empregador. Para evitar contudo dúvidas, sobretudo se se considera a confusão teórica que reina no assunto, seria necessário que o Estatuto precisasse a matéria. Nos termos vagos e excessivamente gerais em que a lei conceitua o emprego rural, há o risco de ver o trabalhador meeiro excluído da categoria de empregado, e pois privado dos benefícios da lei. E isso não constitui simples suposição, pois é de lembrar que no referente às férias remuneradas e outros benefícios de que já de longa data deveriam gozar os trabalhadores rurais, há julgados que excluem do benefício os meeiros, sob pretexto de não serem empregados...

Mesmo contudo no caso de se reconhecer o meeiro como incluído na definição de empregado rural dada pelo Estatuto - seria o trabalhador remunerado in natura, o que o citado artigo $3^{\circ}$ prevê -, a sua situação não se acharia suficientemente considerada, pois não há disposição alguma que regule devidamente as relações de trabalho específicas do meeiro, como sejam a divisão e disposição do produto, além de outras que somente uma análise cuidadosa do assunto, o que ainda não foi realizado, revelaria. A questão da disposição da metade do produto que cabe ao trabalhador é da maior importância, pois frequentemente o proprietário-empregador (o fazendeiro) obriga o meeiro a lhe entregar essa meia por preço inferior ao do mercado. E mesmo quando está prevista a livre disposição, pelo trabalhador, de sua meia, o que lhe permitiria em princípio vender livremente o produto pelo justo preço, essa liberdade pode ser contornada pelo empregador, e assim é muitas vezes com o simples e fácil expediente de negar ao trabalhador locais apropriados para armazenar seu produto depois de colhido e até a venda; ou então cobrando um preço arbitrário por essa armazenagem. Tudo isso precisa naturalmente ser previsto na lei, a fim de evitar fraudes que a inutilizem em benefício do empregador. 
Outra situação semelhante a essa do meeiro que acabamos de analisar, e que torna possível aos empregadores rurais contornarem a lei e privarem seus empregados dos benefícios legais (situação essa de que o Estatuto nem remotamente cogita, e que ele ignora de todo, embora já venha ocorrendo amiúde), é a da dissimulação da relação de emprego sob a forma de contrato de empreitada. Fazendo o empregado executar suas tarefas como "empreiteiro" (o que em boa parte das atividades da agropecuária é muito fácil, como seja no plantio, no trato e na colheita do produto), pode o empregador livrar-se, dentro de uma interpretação da lei perfeitamente aceitável, das obrigações impostas pelo Estatuto e quaisquer outras leis reguladoras do trabalho rural.

Ainda há outras situações que o Estatuto não define e esclarece suficientemente, de maneira a assegurar a todos os empregados o pleno gozo dos benefícios social-trabalhistas, Lembremos os casos em que a remuneração do trabalhador se faz parcialmente com o direito a ele concedido de realizar culturas por conta própria, ou utilizar pastos e outros locais para animais ou criações de que porventura disponha. Há uma referência ao assunto no artigo 41 e seu parágrafo único, do Estatuto. Mas tem caráter excessivamente geral e vago, e não prevê nem resolve a maior parte das tão variadas situações decorrentes daquele tipo de remuneração.

Em suma, e sem entrar em mais pormenores que não interessariam aqui, pois o que procuro agora é tão somente exemplificar as graves deficiências e insuficiências do novo Estatuto do Trabalhador Rural, essa lei não tomou na devida conta a grande variedade de relações de trabalho e emprego da agropecuária brasileira. Não as regulou assim, deixando o assunto em termos vagos, o que ameaça privar eventualmente uma boa parte dos trabalhadores rurais brasileiros de proteção adequada. Além de abrir portas largas a toda ordem de disputas e chicanas que naturalmente operarão sobretudo em prejuízo do trabalhador, como por certo acontecerá nas nossas condições de incipiente organização e desorientada ação das massas trabalhadoras rurais, em face de sólidos e bem resguardados interesses conservadores que ainda dominam completamente o campo brasileiro e a maior parte dos órgãos administrativos e judiciários que nele operam.

Isso teria sido evitado, ou pelo menos muito atenuado, se durante a discussão e votação do projeto do Estatuto, o assunto fosse acompanhado atentamente pelas forças políticas de esquerda e progressistas, naturalmente grandes interessados no caso. O Estatuto, na forma em que se apresenta, revela claramente a displicência com que foi elaborado, o que resultou na insuficiente informação e preparação de seus redatores acerca da realidade brasileira. Eles mostram ignorá-la em boa parte, o que, sejamos justos, não é somente nem mesmo principalmente de sua culpa. A matéria, altamente complexa, ainda muito pouco estudada cientificamente, e praticamente desconhecida, no seu conjunto, por economistas, sociólogos e juristas brasileiros (não se cita, acredito, nenhum trabalho sistemático e geral a respeito da questão), essa matéria das relações de trabalho na agropecuária brasileira deveria ter sido amplamente debatida enquanto se encontrava pendente de decisão do Congresso. Isso atrairia o interesse geral, em particular dos estudiosos e técnicos em questões dessa ordem, o que teria permitido a elaboração de um texto legal capaz de efetivamente atender de maneira conveniente aos fins visados, o que infelizmente só em parte, e parte reduzida, se verificou no Estatuto tal como foi promulgado.

Penso que é da maior importância indagar das razões do desinteresse que acompanhou a elaboração do Estatuto. Desinteresse que parece ainda perdurar, pois a lei, publicada há mais de dois meses, não mereceu até agora, que se saiba, um exame sério, nem foi objeto nas associações de classe de trabalhadores e órgãos políticos e administrativos competentes, de análise e crítica. Nem ao menos lhe foi dada publicidade conveniente, pois afora a publicação oficial, não sei de outra com a necessária difusão. Mesmo os setores mais interessados no assunto, ou que deveriam por ele se interessar, como sejam em particular as forças políticas de esquerda e progressistas, não despertaram ainda para a compreensão da importância da matéria. Como se explica isso num momento precisamente em que a questão agrária atrai tanto as atenções? Essa indagação contribuir, assim penso, para um ajustamento de posições telúricas que têm constituído por suas graves falhas, a meu ver, um dos principais obstáculos opostos à marcha constritiva da reforma agrária entre nós.

Realmente, a atenção principal e quase única nessa matéria da reforma agrária, se tem indevidamente concentrado no problema da subdivisão da propriedade fundiária, em prejuízo de outros aspectos pelo menos tão importantes, como é esse precisamente da legislação socialtrabalhista aplicável ao campo de que nos vimos ocupando. Ora não somente a subdivisão da propriedade fundiária está longe de constituir em todos os casos, e mesmo nos principais, o caminho acertado e mais fácil e 
seguro para a reforma agrária, como essa própria subdivisão, quando se recomenda, será enormemente facilitada e frequentemente até possibilitada pela efetiva aplicação preliminar de uma legislação reguladora das relações de trabalho e emprego rural, e protetora do trabalhador.

Vejamos por que. Boa parte da agropecuária brasileira, particularmente em seus setores mais importantes e fundamentais que serão decisivos no encaminhamento da reforma agrária no Brasil - como entre outros o da cultura cafeeira, da cana-de-açúcar, do cacau, a principal parte da rizicultura, bem como da fruticultura (da banana, das frutas cítricas, que são as principais), e assim outros setores, inclusive da pecuária -, se acha organizada na base da grande exploração rural (fazenda, engenho, usina de açúcar, estância etc.) que tem como elemento constitutivo essencial a relativa extensão, nuns casos mais, noutros menos, da área fundiária ocupada e explorada. Não é evidentemente possível falar aí em "subdivisão" e retalhamento da propriedade, o que significaria a desorganização da produção nas bases em que atualmente se apoia; e exigiria a reorganização do sistema produtivo pela substituição da grande exploração de produção centralizada e concentrada, pelo pequeno produtor individual. É isso realizável? Penso que não. Mas seja como for, o fato é que essa mudança de sistema nunca foi objeto de discussão, e nem ao menos se pensou, ao que se saiba, em propor as formas práticas de a realizar. Como por exemplo substituir as propriedades canavieiras do Nordeste, as fazendas de cacau da Bahia e as de café de São Paulo, as fazendas de gado de Minas Gerais ou as estâncias gaúchas, como substituí-las e suprir as funções econômicas e produtivas que desempenham, por uma organização camponesa de pequenos produtores individuais? Não sei de ninguém que tenha proposto a questão nesses termos. Seria portanto inócuo discuti-lo agora.

Há mais contudo, pois uma reforma dessa natureza e profundidade que significaria uma transformação completa da estrutura e organização dos principais setores da nossa economia agrária, não é possível realizar-se se não como resultante de um amplo movimento social reivindicatório. Sem uma base social dessa ordem, não se pode esperar, a não ser em fantasia longinquamente afastada da vida real e concreta, a efetivação de reforma de tamanho vulto e alcance econômico e social. Seria naturalmente ingenuidade pura imaginar que um simples texto legal, estabelecendo a reorganização de nossas principais atividades agrárias e dando-lhes estrutura e funcionamento da produção completamente distintos e originais, tivesse a virtude, somente por si, e sem o amparo, impulso e instrumento de poderosas e ativas forças sociais, de determinar tais consequências. Ora não se apresenta nenhum sintoma ponderável da ação dessas forças. As reivindicações dos trabalhadores empregados na grande exploração rural brasileira vão noutro sentido que não o do fracionamento da base fundiária em que se assenta aquela grande exploração; e o da transformação deles, de empregados que são, em pequenos produtores individuais e autônomos. As reivindicações desses trabalhadores são as de "empregados", que é a sua situação econômica e social. A saber, reivindicações por melhores condições de trabalho e emprego. E de um tipo desses de reivindicações não é possível esperar que resulte uma ação voltada para a subdivisão e retalhamento da propriedade e destruição com isso da grande exploração. $\mathrm{Se}$ assim fosse, as reivindicações pendentes deveriam conter, em gérmen, a solução das questões econômicas e de ordem técnica que se proporiam numa tal transformação do sistema produtivo. O que não é o caso.

O caminho da reforma agrária no caso da grande exploração rural seria assim outro. É aliás esse o pensamento, hoje, embora ainda mal ou insuficientemente formulado e claro, da generalidade dos proponentes da reforma agrária - daqueles está claro que efetivamente a querem, e não dessas forças que se dizem hoje do "centro", e que não podendo mais se opor de forma aberta à palavra de ordem da reforma, exteriormente a aceitam, mas na realidade procuram escamoteá-la. Excluídos estes cuja posição não interessa agora considerar, a generalidade dos proponentes da reforma agrária sugere para o caso da grande exploração rural a conservação do sistema, mas na base da propriedade coletiva. Em outras palavras, a grande exploração se realizaria por cooperativas de produção, cujos membros seriam os próprios trabalhadores empregados na mesma exploração. Entre outros, encontramos esse ponto de vista expresso na Declaração aprovada pelo I CONGRESSO NACIONAL DE LAVRADORES E TRABALHADORES AGRÍCOLAS reunido em Belo Horizonte em 1961 (publicada em NOVOS RUMOS, número de 24/30 de novembro de 1961).

A ideia, não há dúvida, é sedutora. Mas trata-se de saber se é praticável de forma generalizada. há que ponderar em primeiro lugar que a organização em cooperativa nunca se propôs, nem mesmo remotamente, entre os trabalhadores rurais empregados na grande exploração rural brasileira. É algo que chega a eles de fora, e lhes é completamente estranho. Não constitui evidentemente boa norma política "imaginar" por essa forma 
soluções para problemas econômicos e sociais. Estas soluções se devem apresentar nos próprios fatos da realidade concreta; devem estar incluídos dialeticamente nesses fatos, e não resultarem de concepções abstratas imaginadas e inventadas a propósito como seria o caso, para os trabalhadores empregados rurais brasileiros, de se organizarem e associarem num sistema como este de cooperativas que lhes é completamente estranho, e para o qual não estão em nada dispostos.

Além desse vício de origem da solução cooperativista proposta para a reforma da grande exploração rural, pura invenção que é, sem raízes na realidade concreta, há que ponderar se existem condições, desde logo, para essa autodeterminação, pelos trabalhadores rurais, das empresas agrárias em que estão empregados. Não é de crer que isso se dê. É preciso não esquecer que falta à maior parte e mesmo generalidade da massa de trabalhadores empregados nas grandes explorações brasileiras - e isso por força da própria situação em que se encontram - preparo suficiente para assumirem a responsabilidade da gestão coletiva das empresas onde trabalham. Tratase em regra de trabalhadores temporários e sem raízes nos locais onde exercem suas atividades, seja porque se empregam apenas sazonalmente para a realização de certas e determinadas tarefas - como se dá na colheita da cana-de-açúcar -, seja porque transitam constantemente de uma para outra propriedade, de uma para outra região à procura de ocupação e melhores condições de trabalho, como ocorre via de regra em São Paulo. Particularmente no que respeita aos trabalhadores nordestinos que constituem hoje talvez o maior contingente de trabalhadores rurais do Estado. Não se pode evidentemente esperar num tipo desses de trabalhadores as condições necessárias para a gestão de empreendimentos em que eles não se acham integrados e a que não se ligam senão pelos débeis laços de um emprego que eles mesmos sabem precário. Emprego aliás em que não passam de simples executores de tarefas, sem que nunca lhes tenha sido dada nada, nem podia ser dada a oportunidade de deliberação sobre a maneira de executar essas tarefas. É preciso não confundir, como frequentemente se faz, a situação do trabalhador empregado na grande exploração brasileira, com a do verdadeiro camponês, que esse sim, como produtor que é, ou com essa tradição de produtor (é o caso por exemplo do camponês europeu, seja ou não proprietário), é ao mesmo tempo um trabalhador e executor de tarefas, e um dirigente desse trabalho e dessa execução. Não é essa, sabem-no todos que conhecem o meio rural brasileiro, a situação da generalidade dos trabalhadores das fazendas, engenhos, usinas, estâncias do Brasil. Situação essa afim, e frequentemente idêntica à do trabalhador da indústria. Isto é, de simples empregado, sem perspectivas sobre os problemas gerais de administração e gestão da produção. $\mathrm{E}$ que nem procura essa perspectiva que não $\mathrm{o}$ interessa, preocupado unicamente como se encontra com a remuneração que percebe no emprego e com as demais condições desse emprego.

Já existe aliás nesse particular da transformação da grande exploração rural em cooperativa de trabalhadores nela empregados, uma experiência de grande amplitude que nos é fornecida pela revolução cubana. Em Cuba, tanto como no Brasil, a produção agrária, representada aí na sua maior parte pela cultura da cana-de-açúcar, se achava organizada sobretudo na base da grande exploração agrícola. A reforma agrária introduzida pela revolução, respeitou o sistema, como não poderia deixar de ser; mas transferiu as propriedades canavieiras para cooperativas de trabalhadores nela empregados. Essas cooperativas, no entanto, nunca funcionaram normalmente, e de fato não constituíram cooperativas senão de nome. Conservaram-se sob a tutela estreita da administração central do país, inclusive no que se refere à escolha dos seus dirigentes, nomeados em regra por aquela administração. As poucas exceções feitas aos princípios teóricos das cooperativas deram geralmente maus resultados, e afetaram desfavoravelmente não ao a eficiência da produção, como os próprios interesses imediatos dos trabalhadores. Por esses motivos, foi-se aos poucos abandonando o plano inicial, e transformaram-se as cooperativas em empresas estatais, as chamadas "granjas del pueblo".

Está aí uma experiência que não pode deixar de ser considerada no planejamento das reformas da estrutura e funcionamento da agropecuária brasileira. Essa experiência nos mostra que a evolução da grande exploração rural não é para a cooperativa, e sim para a empresa estatal. Assim sendo, a menos que se proponha desde logo a estatização da grande exploração, o que não é entre nós o caso, e nem sequer foi aventado como norma geral, inclusive pelos reformadores cuja teoria estamos discutindo, a menos isso, o que efetivamente se propõe relativamente à grande exploração rural na etapa histórica atual em que nos encontramos, são as reivindicações trabalhistas em torno das relações de emprego, e a promoção das medidas legais de proteção do trabalhador empregado e melhoria de suas condições de trabalho. O paralelismo, a esse respeito e no fundamental 
da questão, com o que ocorre na indústria, é perfeito. A esse propósito, cumpre ainda lembrar a experiência cubana e o considerável papel representado antes da revolução, desde longa data, bem como no desencadeamento e consolidação dela, pelos trabalhadores rurais da agricultura canavieira organizados em sindicatos e lutando na base de reivindicações trabalhistas.

A conclusão é tanto mais exata que a melhoria das condições de trabalho e de vida dos trabalhadores empregados na grande exploração rural, alcançada pelo duplo e concorrente efeito das lutas reivindicatórias desses trabalhadores e de uma legislação social-trabalhista adequada e tendente para aquele fim, abrirá desde logo amplas perspectivas para transformações imediatas de grande alcance, e dentro ainda da fase atual de relações capitalistas de produção, na estrutura agrária brasileira e nas condições gerais, econômicas e sociais, de nossa economia agropecuária. É o que se pode concluir do fato que os baixos padrões de produtividade e ínfimo nível tecnológico que predominam na generalidade da agropecuária brasileira, se devem em primeiro e principal lugar ao baixo custo da mão de obra. É somente graças a isso que boa parte das grandes explorações rurais brasileiras, apesar dos rotineiros processos de produção que empregam, conseguem se manter e são rentáveis. Isso porque, assegurada a rentabilidade da empresa a mercê do baixo custo da mão de obra empregada, dispensam-se aperfeiçoamentos tecnológicos, maiores atenções na condução das atividades produtivas e intensificação da produção. Procedimentos esses que exigem maiores recursos de capital, e mais aplicados esforços dos proprietários. O estatuto miserável do trabalhador rural brasileiro permite dispensar tais despesas e esforços maiores, pois o que se perde assim com a baixa produtividade é recuperado à custa do preço insignificante da mão de obra. É claro que numa situação como essa a valorização do trabalhado estimulará e forçará a melhoria da produtividade pelo emprego de processos e técnicas de mais alto nível e rendimento.

\section{Alberto Passos Guimarães: As Três Frentes da luta de Classes no CAMPo Brasileiro ${ }^{1}$}

Um dos muitos méritos da "Declaração" e das "Teses" (o autor se refere à Declaração de março de 1958 e Teses para discussão do V Congresso de 1960 - RS) consiste em abrir novos horizontes à formulação da política dos comunistas no campo. Ao colocarem no devido lugar a contradição imperialista, ressaltando sua predominância sobre as demais contradições, inclusive sobre a contradição com os restos feudais, aqueles documentos possibilitaram uma compreensão nova, mais ampla e mais profunda, de nosso problema agrário.

$\mathrm{O}$ fato de aceitar-se como predominante a contradição imperialista e de admitir-se como principal inimigo do nosso povo o imperialismo norteamericano implica, logicamente, reconhecer o papel primordial que aquela contradição desempenha em todos os aspectos da revolução brasileira. Por conseguinte, implica reconhecer que a opressão imperialista sobre a nação é mais forte do que a opressão feudal.

E se tal conclusão é verdadeira para toda a nação e para todo o povo é evidentemente verdadeira para nossa população rural, e em particular para os camponeses.

A contradição com o imperialismo - e com o imperialismo norteamericano muito especialmente - não é nem pode ser uma contradição apenas com a parte urbana da sociedade, mas com o seu conjunto; não pode ser uma contradição apenas com um setor da economia, mas com a economia brasileira em conjunto. $\mathrm{E}$, por isso, não é nem pode ser uma contradição dominante apenas para a indústria e não dominante ou subordinada para a agricultura.

Não raciocinam exatamente nesses termos - segundo me parece alguns companheiros da oposição "esquerdista", os quais, embora se mostrem indignados contra a suposta "separação mecânica" que as "Teses" teriam feito das duas contradições fundamentais, tratam, eles próprios, o problema agrário à parte dos demais problemas. E, ao assim procederem,

${ }^{1}$ Publicado em duas partes na Tribuna de debates do V Congresso do PCB. Novos Rumos, Rio de Janeiro, edições de 22 a 28/7/60 e de 29/09 a 4/8/60. 
fazem de fato uma separação mecânica entre as duas contradições, raciocinando em termos tais que dão a entender que, no campo, a contradição principal é com os restos feudais (e os latifundiários) e não com o imperialismo. Para eles, segundo pude compreender, a contradição com o imperialismo deixaria ali de atuar ou, na melhor das hipóteses, perderia sua condição de principal e passaria à de subordinada.

Essa incompreensão do caráter dominante (em geral, para todos os aspectos) da contradição imperialista apresenta-se com maior evidência no artigo de Nestor Vera (Novos Rumos, $\mathrm{n}^{\mathrm{o}}$ 66), onde a luta de classes no campo brasileiro aparece reduzida a apenas duas frentes: a frente dos camponeses contra os restos feudais e a frente dos assalariados ou operários agrícolas contra o patronato rural.

Como se explica que esses companheiros, tão "exigentes" a respeito de um problema importante como de fato é a aliança operário camponesa, subestimem e mesmo abandonem a luta contra o imperialismo no campo? Não é a luta contra o imperialismo no campo o fator mais relevante, o fator principal na presente etapa, para a mobilização de TODO o povo e, consequentemente, para a formação da aliança operário-camponesa?

Essa subestimação só se explica pelas dificuldades que têm os companheiros da oposição "esquerdista" em se livrarem do subjetivismo, do dogmatismo e do sectarismo.

\section{A opressão imperialista no campo}

Dissemos que a opressão imperialista é mais forte, também no campo, do que a opressão feudal. Será verdadeira essa afirmação?

Pensamos que é verdadeira. E se não o fosse, não seriam também completamente verdadeiras as suas premissas: a de que a contradição dominante é com o imperialismo e a de que o imperialismo norte-americano é o inimigo principal de todo o povo brasileiro.

A verdade dessa afirmação pode demonstrar-se, em primeiro lugar, pelo fato objetivo, bastante óbvio, de que a espoliação imperialista é a causa histórica mais longínqua e determinante do atraso semifeudal de nossa agricultura, atraso que decorre, fundamentalmente, da evasão de parte substancial da renda nacional para as metrópoles, durante toda a nossa história.
Pode demonstrar-se essa verdade, em segundo lugar, com o fato de que uma parcela considerável da renda nacional que se evade, e que representa o tributo de nossa dependência aos monopólios estrangeiros, não é paga pelos latifundiários, mas, sim, é por estes extorquida a custa de uma intensificação ao mais alto grau da exploração semifeudal da massa camponesa.

Em terceiro lugar, pode essa verdade demonstrar-se pelo fato de recaírem sobre a massa trabalhadora do campo, mais do que sobre qualquer outra camada do povo, os ônus resultantes quer da pressão direta dos monopólios estrangeiros - em particular dos norte-americanos - para o aviltamento dos preços dos produtos primários, quer da pressão direta e indireta desses mesmos monopólios sobre o conjunto da economia nacional.

\section{A teoria e o método da luta de classes}

Afirmava Lênin, com absoluta propriedade, que o livre desenvolvimento da luta de classes no campo "é o ponto fundamental e central da teoria do marxismo revolucionário na questão agrária" $(O$ programa agrário da social democracia russa, cap. V).

Este ponto não é só uma pré-condição indispensável para o esclarecimento da questão agrária, como principalmente é o método adequado para levar às suas ulteriores consequências a revolução agrária antifeudal no Brasil. A luta de classes constitui, pois, o fio condutor através do qual poderemos chegar tanto à compreensão teórica dos nossos problemas agrários, quanto às soluções práticas desses mesmos problemas.

Dispondo desse método deveremos saber utilizá-lo para abrir caminho, no emaranhado de contradições em que se entrelaçam as velhas e as novas relações econômicas e sociais de nosso quadro rural, até a realização do objetivo fundamental da revolução agrária que é a abolição do monopólio da terra.

Nesse sentido, a primeira questão a elucidar, se desejarmos ter perspectivas claras sobre nossa linha programática e tática no campo, é a questão das formas através das quais deve desenvolver-se, o mais livremente possível, a luta de classes no seio do movimento agrário no Brasil.

Lênin, em um de seus trabalhos sobre a questão agrária na Rússia czarista, escreveu: "Duas formas essenciais da luta de classe se entrelaçam 
hoje no campo russo: $1^{\circ}$ ) a luta do campesinato contra os proprietários agrários privilegiados e contra os vestígios da servidão; $2^{\circ}$ ) a luta do proletariado rural nascente contra a burguesia rural" (Projeto de programa do nosso partido, 1899).

Poderíamos aplicar à situação brasileira atual essa mesma caracterização que se ajustava à antiga Rússia?

Acho que não. Quero acreditar que, nas condições atuais de nosso país, as formas essenciais da luta de classe no campo são três e não duas, como as que correspondiam à situação da revolução agrária da Rússia czarista.

Cometeríamos um grave equívoco se pretendêssemos transplantar esquematicamente para a situação em vigor em nosso país aquela caracterização de Lênin, a qual se aplicava às bastante diversas condições russas de outra época. Mesmo que nos dois países fossem semelhantes em todas as demais condições, bastaria considerar uma distinção básica - a de ser o nosso país, ainda hoje, um país dependente do imperialismo, enquanto que a Rússia de antes de 1917 era um país imperialista.

Precisamente por isso, não existem no Brasil atual apenas duas, mas três formas essenciais da luta de classes: $1^{\circ}$ ) a luta de todo o campesinato contra as várias modalidades da opressão e da espoliação imperialista; $2^{\circ}$ ) a luta do campesinato contra as sobrevivências do pré-capitalismo e contra os latifundiários; e $3^{\circ}$ ) a luta dos assalariados e semiassalariados rurais contra os patrões, grandes proprietários de terra.

Essas três formas essenciais da luta de classe no campo brasileiro não se acham separadas entre si, mas sim entrelaçadas, como acentuava Lênin, e embora sejam três frentes diversas, com aspectos peculiares e específicos, são partes integrantes e inseparáveis do processo da revolução agrária no Brasil.

Assim, a luta de todo o campesinato contra o imperialismo é também uma luta contra as sobrevivências pré-capitalistas e pela melhoria da situação dos assalariados. A luta do campesinato contra as sobrevivências do pré-capitalismo é, ao mesmo tempo, uma luta para fortalecer o movimento anti-imperialista e o movimento reivindicatório dos assalariados rurais. A luta dos assalariados e semiassalariados contra os patrões grandes proprietários de terras prepara as condições para a unidade da classe operária e para a aliança com o campesinato, resultando no fortalecimento da luta anti-imperialista e da luta antifeudal.

\section{As transformações burguesas e as forças motrizes}

Com a teoria da luta de classes o marxismo, como é sabido, enriqueceu o conhecimento humano, incorporando-lhe uma concepção verdadeiramente científica acerca do desenvolvimento das sociedades. A essência dessa teoria reside na descoberta da lei fundamental do desenvolvimento da sociedade humana, do elemento dinâmico que aciona o progresso social e esse elemento dinâmico é a luta das classes em ascensão contra as classes em decadência. A luta de classes representa, portanto, a força que move a roda da história, o motor do desenvolvimento histórico.

Se não levarmos em conta essa concepção científica não penetraremos no âmago do problema agrário e teremos dele tão somente uma visão estática, um quadro meramente fenomenológico, como os que nos são apresentados pela sociologia vulgar.

Ensina a teoria da luta de classes que é preciso partir das classes novas, em ascensão, que aparecem em determinado momento da história da sociedade humana, para seguir o fio condutor que nos levará a descobrir as leis gerais e particulares do desenvolvimento social.

Deste modo, na sociedade brasileira, a fim de podermos escolher acertadamente nossas posições programáticas e táticas, será necessário partir das aspirações, dos interesses e das perspectivas históricas das classes novas em ascensão, isto é, do proletariado, dos camponeses, e da intelectualidade, as quais constituem as forças motrizes da revolução brasileira.

Entretanto, as condições objetivas e a situação concreta do Brasil de nossos dias impõem-nos uma condição essencial e preliminar, sem a qual essas classes novas em ascensão não poderão desenvolver-se livremente e abrir caminho para o progresso da sociedade brasileira. Essa condição essencial e preliminar, cujo caráter presente independe de nossa vontade e de nossa ação, é a realização das transformações progressistas de caráter burguês ou, o que quer dizer a mesma coisa - o desenvolvimento do capitalismo.

A esse respeito também é oportuno invocar o pensamento leninista. Respondendo àqueles que ontem, como ainda hoje, levantavam dúvidas e faziam objeções à libertação do desenvolvimento burguês no campo russo, Lênin esclarecia: "O proletariado distingue-se precisamente das outras classes oprimidas pela burguesia e opostas a esta última, por basear suas 
esperanças não sobre uma interrupção do desenvolvimento burguês, não sobre o enfraquecimento ou a atenuação da luta de classes, mas ao contrário sobre seu desenvolvimento mais completo e mais livre sobre a aceleração do progresso burguês. Numa sociedade capitalista em desenvolvimento é impossível (grifado no original, APG) suprimir os vestígios da servidão que entravam o progresso, sem reforçar e consolidar com isso a burguesia" ( $O$ programa agrário da social democracia russa, cap. V).

Lênin afirmava, também, que "o proletariado não defende todas as medidas que aceleram o progresso burguês, mas somente aquelas que contribuem diretamente para reforçar as capacidades de luta da classe operária e em favor de sua libertação".

Isso quer dizer que o proletariado não somente deve como pode intervir no sentido de um determinado tipo ou curso de desenvolvimento capitalista. E se tal coisa era possível à época de Lênin, na Rússia czarista, muito mais o é hoje, nas condições atuais do Brasil e do mundo.

Prestemos bem atenção ao fato de que se, por um lado, independe de nossa vontade o caráter atual, objetivo, das transformações progressistas em nosso país (que só podem ter caráter burguês), por outro lado, o tipo ou curso dessas transformações pode ser modificado segundo a vontade ou a ação política das forças motrizes da revolução, isto é, do proletariado e seus aliados.

Por assim entender o problema, Lênin estabelecia clara distinção entre o caráter burguês, objetivo, das transformações progressistas realizadas em determinada situação e o caráter não burguês, e portanto socialista, da ação de suas forças motrizes: "Burguês por seu conteúdo econômico e social - escreveu Lênin - o movimento de libertação não o é por suas forças motrizes. Não é a burguesia que pode ser sua força motriz, mas o proletariado e o campesinato. Por que é isso possível? Porque o proletariado e o campesinato, mais ainda do que a burguesia sofrem as sobrevivências da servidão e sentem necessidade mais premente de conquistar a liberdade e quebrar o jugo dos senhores de terra" (A questão agrária e as forças da revolução, abril de 1907).

\section{O caminho reformista e o caminho revolucionário}

Dois são os cursos ou caminhos possíveis do desenvolvimento capitalista no campo brasileiro: um, revolucionário, outro, reformista.
Qual é, desses dois, o tipo ou curso do desenvolvimento capitalista no campo que o proletariado deve apoiar?

O proletariado e as forças mais progressistas da sociedade brasileira devem apoiar as transformações burguesas no campo que resultem na destruição dos laços com o feudalismo, que resultem na destruição das formas pré-capitalistas, e expressem um desenvolvimento democrático apoiado no capitalismo de Estado e na propriedade camponesa.

Este é o curso revolucionário do desenvolvimento do capitalismo no campo, o qual se opõe ao curso reformista que consiste nas transformações burguesas que se realizam sem alterar as bases do antigo regime.

As transformações burguesas de conteúdo revolucionário podem ser realizadas, e o têm sido no Brasil, quer de forma violenta, quer de forma pacífica, sem ou quase sem violências.

Em nosso passado não muito distante, quando no seio da sociedade brasileira se desenvolvia a luta de classes entre senhores e escravos, e mais amplamente, entre os que apoiavam a oligarquia escravocrata e os que apoiavam o movimento abolicionista, esta luta terminou após numerosos levantes de escravos, com a vitória pacífica dos abolicionistas. Essa foi uma transformação burguesa de extraordinária importância histórica que se inclui entre as que podemos considerar de conteúdo revolucionário, pois, mesmo conservando-se o monopólio da terra, destruiu as bases do antigo regime escravista e abriu caminho a novas relações econômicas e sociais no campo.

Exemplos mais recentes de transformações burguesas de conteúdo revolucionário, e obtidas por meios pacíficos, mediante "reformas", igualmente não são raras. Entre estas podem ser citadas várias das lutas vitoriosas dos posseiros pela validação de títulos de propriedade.

A expropriação do Engenho da Galileia, em Pernambuco, alcançada depois de uma série de lutas a que não faltou a violência da polícia, é outro exemplo de reforma que teve um desfecho pacífico. As transformações realizadas, com a divisão de um latifúndio semifeudal entre camponeses, têm caráter burguês e, por seu conteúdo, por sua essência, podem classificar-se entre as transformações revolucionárias. Apesar de concretizada mediante uma "reforma" concedida pelo governo, a expropriação não teve conteúdo reformista, não se fez para conservar as velhas relações de produção existentes; desse ato resultou uma mudança na 
estrutura da propriedade que, de um latifúndio semifeudal, se transformou num certo número de propriedades camponesas e resultou, também, numa mudança do regime de trabalho, pois os antigos camponeses semifeudais se tornaram camponeses burgueses.

Detenhamo-nos nesse acontecimento para extrair dele outras conclusões. Poder-se-á argumentar que a expropriação do Engenho da Galileia constitui apenas um caso isolado e que não poderá repetir-se em elevada escala, por diversos motivos. Mas também se poderá argumentar que esse caso só é um caso isolado devido ao grau ainda incipiente da luta de classes no campo e que, com o desenvolvimento dessa luta e com o fortalecimento do ainda atrasado movimento camponês aumentarão as possibilidades de expropriações.

O importante é verificarmos que expropriações semelhantes não eram comuns antes e nem sequer aconteciam. E essa, da Galileia, já denota um grau mais elevado do que o anterior da luta de classes no campo.

Que forças, que classes se puseram à frente dessa luta e a conduziram até a vitória? As classes em decadência ou as classes em ascensão? Não parece evidente que, em face do conteúdo revolucionário das transformações realizadas, embora ainda constituam um caso isolado, tais transformações obedeceram a princípios justos e foram uma consequência de um determinado impulso dado acertadamente pelas forças motrizes da revolução brasileira?

\section{Agora analisemos o fato, de outros pontos de vista.}

Parece-nos claro que se a propriedade expropriada pertencesse à Standard Brands, à Anderson Clayton ou a qualquer outra empresa norteamericana, a luta não teria chegado a bom termo senão em outras condições. Seria, seguramente, necessário para lograr êxito, nesse caso, que não apenas a forma antifeudal da luta de classes no campo atingisse um nível mais alto, mas também que já estivesse igualmente em nível alto a forma anti-imperialista da luta de classes no campo. Isso também serve para demonstrar - creio eu - como inegavelmente é mais forte a contradição com o imperialismo do que a contradição com o feudalismo, também no que se refere ao movimento agrário.

Outro aspecto a considerar-se e a comparar-se é o da forma pacífica que predominou no caso do Engenho da Galileia. Se tivesse predominado a violência, teria sido idêntico o conteúdo revolucionário das transformações realizadas. Mas, teria a luta logrado êxito? Neste sentido particular, não seria a forma violenta uma forma inadequada e capaz de levar ao fracasso o objetivo visado?

Então, é preciso concluir, embora isso desgoste profundamente aos "esquerdistas" em geral e em especial aos "esquerdistas" da oposição, que ao menos em determinadas condições a forma pacífica é mais vantajosa e mais eficaz, do ponto de vista da prática revolucionária, que a forma violenta. Isso também serve para demonstrar que existe, hoje, a possibilidade real de transformações pacíficas, mesmo no campo, e apesar de todas as conhecidas debilidades de nosso movimento camponês. Agora essa possibilidade existe ainda como exceção, mas, amanhã, segundo todas as probabilidades indicam, poderá existir como regra.

É também importante notar que a violência não basta para testemunhar o conteúdo revolucionário das transformações burguesas. Muitas das transformações burguesas realizadas por meios violentos têm cunho reformista, pois representam uma conciliação com as formas de domínio correspondentes a regimes historicamente superadas. Os latifundiários, como atesta nossa história, muito frequentemente se têm servido da violência contra a massa camponesa para impor o seu curso - o curso reformista - às transformações burguesas. A evolução do latifundismo feudal para o latifundismo burguês, principalmente na agricultura cafeeira, foi em muitos casos realizada violentamente, sendo que a iniciativa da violência coube à classe opressora, aos latifundiários.

Indubitavelmente, as transformações burguesas de conteúdo revolucionário obtidas por meios não violentos constituem uma, entre outras, das comprovações práticas da tese, da possibilidade real de um caminho pacífico para a revolução brasileira. De fato, se as forças motrizes da revolução, dentro da ampla frente nacional democrática, conseguirem transformar os exemplos isolados de nossa história na regra de conduta da luta de classes no campo, isto é, se conseguirem multiplicar por toda a parte as reformas (pacíficas) de conteúdo revolucionário que importem na destruição das bases do feudalismo, no desenvolvimento da propriedade camponesa e das relações agrárias do tipo capitalista - eis aí, em toda a sua perspectiva, o caminho pacífico levado à prática pelas massas do campo. 
É evidente que esse caminho encontra sérios obstáculos pela frente e que sua escolha não depende da decisão apenas da massa camponesa, mas da resistência cada vez mais desesperada que a classe espoliadora decadente possa oferecer à ação do movimento democrático.

Entretanto, o fato de que a iniciativa da violência passe às mãos dos inimigos do povo terá transcendental importância como fator político favorável à mobilização das massas populares e ao desenvolvimento da revolução.

Por tudo isso se verifica que, apesar das múltiplas faces com que o problema agrário se configura, nas complexas condições brasileiras, suas soluções sempre estarão relacionadas, de uma ou de outra maneira, sob um ou outro aspecto, com o desenvolvimento da luta de classes. Portanto, se quisermos aplicar um método acertado para descobrir o caminho brasileiro para a revolução agrária antifeudal, não nos resta outra alternativa senão a de tomar como ponto de partida o estudo das particularidades concretas de cada uma das três frentes da luta de classes no campo brasileiro. É o que tentaremos fazer, a seguir.

Afirmam as "Teses" que o "movimento camponês se ressente de grande atraso e é muito baixo o seu nível de organização" (tópico 30). Isso equivale a afirmar que a luta de classes no campo ainda não pôde desenvolver-se livremente, não pôde adquirir ainda um "caráter aberto e consciente", para usar uma expressão de Lênin.

É justa essa afirmação das “Teses"? Creio que é justa.

Os comunistas brasileiros passaram muitos anos enganando-se a si mesmos com uma perspectiva exagerada da revolução agrária. Partindo de premissas certas como as de que havia forte semelhança entre a situação de miséria e opressão feudal em nosso país e a de vários países asiáticos e do Leste europeu, tiravam conclusões erradas sobre uma inexistente analogia entre o grau de maturidade do movimento camponês aqui e o de outras partes do mundo.

Como comparar, por exemplo, o grau de desenvolvimento da luta de classes no campo do Brasil, país de campesinato muito recente, com o daqueles países onde o campesinato tem uma existência milenar? Pode haver grande analogia entre o movimento camponês no Brasil, onde os levantes camponeses se contam nos dedos, e o movimento camponês na Rússia czarista, onde até 1905 tinha havido mais de 2.000 levantes camponeses de importância? Pode haver grande analogia entre o nosso e o movimento camponês no ocidente da Europa, onde por séculos perduraram as guerras camponesas? Pode o nosso movimento camponês ser comparado com o da China, onde as revoltas contra a classe dos latifundiários começaram com a dinastia dos Chin, no ano 221 antes de Cristo, foram-se repetindo séculos afora, passando pela revolta dos Tai-Ping, no século passado, pela revolução agrária de 1928-1937, até culminar com a vitória de 1949 ?

Não é verdade que a mais radical transformação ocorrida no campo brasileiro - a abolição da escravatura - resultou, fundamentalmente, de um movimento impulsionado e dirigido pela pequena burguesia urbana?

Tudo isso não nos leva a negar, absolutamente, a existência da luta de classe no campo, o que seria uma conclusão absurda. Leva-nos, porém, a afirmar que, indiscutivelmente, a luta de classe ainda não adquiriu um "caráter aberto e consciente", ainda não atingiu um elevado grau de desenvolvimento e que o movimento camponês no Brasil está atrasado, não só em comparação com o movimento camponês de outros países, como também em relação ao movimento democrático geral, dentro de nosso próprio país.

Portanto, para formular os problemas da revolução agrária no Brasil, é preciso levar em conta essa situação específica.

Em virtude dessa situação específica, as "Teses" estabelecem que se deve "atribuir uma atenção primordial aos assalariados e semiassalariados agrícolas", os quais, também pelo fato de se acharem menos dispersos e mais concentrados do que em geral a massa camponesa, "são mais suscetíveis de organizar-se" e "podem constituir as bases iniciais para a mobilização das massas camponesas".

As "Teses" oferecem, deste modo, uma contribuição nova para a tática de mobilização das massas do campo, em inteira correspondência com a situação concreta de nosso país e com a linha política em vigor.

A experiência nos mostrou o erro grosseiro de nossa antiga linha "esquerdista", ao pretender começar por meios artificiais uma imaginária "revolução" no campo, com a imposição de práticas aventureiras e desesperadas, completamente desligadas da realidade. 
Só os subjetivistas mais empedernidos poderiam abrigar em suas cabeças a ideia de que seria possível improvisar uma revolução despachando para o campo quatro ou cinco dezenas de pessoas dedicadas, com a missão de "levantar os camponeses"...

Se aqueles companheiros, deformados pelo subjetivismo, se dessem ao trabalho de pensar, acabariam por perceber que há no Brasil onze milhões de trabalhadores rurais, distribuídos por dois milhões de estabelecimentos agrícolas. Quantas pessoas seriam, necessárias para ir ao campo e "levantar os camponeses"? Quinhentos mil? Cem Mil? Ou "apenas" 10 mil?

\section{A frente dos assalariados e semiassalariados}

Assim como seria um sonho fantástico "levantar" os operários mandando "missionários" às nossas 100 mil fábricas, não é um sonho ainda mais fantástico "levantar" os camponeses mandando "missionários" a dois milhões de estabelecimentos rurais?

Afastando-se dessas delirantes fantasias, as "Teses" apontam a maneira certa de atingir em larga escala as massas do campo através dos assalariados e semiassalariados agrícolas, organizando-os por meios legais em suas associações de classe, despertando-os para a luta por seus direitos e reivindicações, elevando o grau de consciência de sua luta de classe.

Portanto, do ponto de vista da construção da aliança operáriocamponesa, a frente da luta de classe dos assalariados e semiassalariados agrícolas (que muito frequentemente aliam à condição de assalariados à condição de camponeses) tem especial preponderância sobre as demais. Por intermédio dessa frente será possível montar as correias de transmissão que irão ligar o proletariado e o movimento democrático das cidades aos camponeses e ao movimento democrático do campo.

Como se compõem e como se distribuem as forças de classe nessa frente?

Não participo da convicção do companheiro Caio Prado Jr., de que os assalariados estão em absoluta superioridade no campo e de que as formas assalariadas já estão predominando de modo incontestável em todos os setores da produção agrícola.
Uma leitura mais atenta dos resultados do último recenseamento nos mostrará o contrário. De acordo com o Censo de 1950, havia nos dois milhões de estabelecimentos agropecuários 11 milhões de trabalhadores, dos quais cerca de dois milhões de pessoas eram as responsáveis pela gestão daqueles estabelecimentos (proprietários e arrendatários à frente da exploração, administradores, etc.); cerca de quatro milhões de pessoas constituíam os membros não remunerados das famílias dos responsáveis isto é, menores e mulheres em sua maioria, que trabalhavam ajudando os chefes da família sem receberem remuneração direta nenhuma; 3,7 milhões eram "empregados" dos estabelecimentos; e 1,3 milhões eram "parceiros".

Desde logo é preciso observar que o Censo excluiu da contagem os "moradores", "agregados", etc., que são pessoas, segundo o Censo, que se "caracterizam pelo fato de prestarem serviços remunerados em dinheiro ou em espécie, com o direito de utilizarem, em proveito próprio, terras do estabelecimento". Estas pessoas, segundo o critério marxista-leninista são camponeses feudais, sem terra, que prestam serviços pessoais. Não se sabendo quanto eles representam no conjunto, os resultados censitários tendem a exagerar o caráter capitalista de nossa mão de obra rural, pois omitem uma parte desta que se inclui no contingente de trabalhadores sujeitos a formas pré-capitalistas de trabalho.

Mas isso não é tudo. A própria conceituação de "empregado", adotada no Censo, mistura os assalariados propriamente ditos (pessoas que trabalham mediante remuneração em dinheiro) com as pessoas remuneradas com parte em dinheiro e parte em produtos que percebiam a maior porção em dinheiro. Assim, um meeiro que trabalhasse todo o ano como meeiro e na época do Censo estivesse, temporariamente, contratado para receber uma parte maior em dinheiro, foi considerado "empregado". É possível, pois, que o número de "empregados" apresentado no Censo esteja acima da realidade da época, e que o de "parceiros", juntamente com o de "moradores", superasse, de fato, o número de assalariados propriamente ditos.

Essas são hipóteses irredutíveis, embora nada o possa afirmar com segurança a respeito. De qualquer modo, a prudência nos aconselha a não exagerar o caráter capitalista de nossa mão de obra rural, tanto mais que, mesmo que fossem todos os 3,7 milhões de "empregados" compostos de assalariados, na sua forma capitalista, esse número, ainda assim, seria inferior à soma dos trabalhadores membros de família (quatro milhões) e 
dos "parceiros" (1,3 milhões), ou seja, 5,3 milhões de pessoas que se dedicavam a prestar trabalho pessoal, pré-capitalista por sua natureza, sem remuneração direta em dinheiro.

Também os "parceiros" do Censo não são parceiros no sentido capitalista mas sim "meeiros" semifeudais pois se trata de pessoas que não têm autonomia econômica, estão subordinadas à administração do estabelecimento, e se enquadram no conceito marxista da renda-produto. Os parceiros autônomos, de natureza capitalista, foram pelo recenseamento considerados no grupo "responsável e membros não remunerados da família", como está dito na Introdução ao volume de Censo Agrícola.

Disso se pode tirar as seguintes conclusões: $1^{\circ}$ ) o número de assalariados agrícolas não é superior ao de trabalhadores agrícolas que fazem, nos moldes pré-capitalistas, prestação pessoal de serviços, muitos deles gratuitamente; $2^{\circ}$ ) dos 3,7 milhões de "empregados", encontrados pelo Censo, não se pode dizer quantos são os assalariados (que recebem em dinheiro) e os semiassalariados (que recebem parte em dinheiro e parte em produtos).

Evidentemente, essas conclusões não nos impedem de reconhecer que, com o desenvolvimento capitalista no campo, o número de assalariados tende a crescer e que as formas assalariadas tendem a se despojar de seus traços feudais, à medida que tenha curso livre a luta de classe do proletariado rural. Entretanto, esses aspectos não podem passar despercebidos a todos quantos tenham de formar uma ideia exata da situação concreta no campo, sem cair em exageros quer a respeito do predomínio das formas capitalistas de trabalho, quer a respeito do papel ainda decisivo das formas pré-capitalistas de trabalho.

Por isso, a organização em sindicatos da massa de assalariados, ainda em número não muito grande, e ainda em estado de pré-consciência quanto a seu papel de classe, é uma tarefa difícil que não depende apenas da dedicação e do valor pessoal dos quadros comunistas, mas principalmente, do apoio do movimento democrático, da cidade e do campo, em favor da extensão, ao meio rural, dos direitos consagrados na legislação trabalhista.

\section{A frente contra o latifúndio}

A frente do campesinato contra os restos do feudalismo e o latifundismo é mais numerosa, mais ampla e mais complexa que a frente dos assalariados e semiassalariados. Ela abrange, em primeiro lugar, o enorme contingente do campesinato pré-capitalista, semifeudal, que inclui os trabalhadores rurais da categoria da renda-trabalho ("moradores", "agregados" e todos os que realizam prestação de serviço gratuito ou semigratuito), os trabalhadores rurais da categoria da renda-produto (meeiros dos diferentes tipos e os considerados pelo recenseamento como "parceiros") e os trabalhadores rurais da categoria da renda-dinheiro ("rendeiros", "foreiros" e arrendatários não autônomos ou semiautônomos como, por exemplo, muitos "arrendatários" do arroz, do algodão, etc. cujas formas de arrendamento, em muitos casos pagos em espécie ou em serviços, não podem considerar-se ainda formas de renda capitalista). Abrange também o campesinato de formação burguesa, isto é, todos os que possuem o domínio ou a posse da terra (proprietários, arrendatários capitalistas, ocupantes ou posseiros).

Os limites da propriedade camponesa poderiam, talvez, estabelecerse, no Brasil, na ordem de 50 hectares, que é a linha divisória até onde o trabalho produtivo da terra repousa sobre a mão de obra familiar, a qual no conjunto das explorações até 50 hectares é mais numerosa do que a mão de obra assalariada. Ter-se-ia, ainda, uma subdivisão desse conceito: os camponeses pobres (com terra), até aproximadamente os limites de 20 hectares, os quais nunca ou quase nunca admitem mão de obra assalariada para o trabalho agrícola, e os camponeses médios (com terra) que trabalhavam suas terras, na maioria das vezes com mão de obra assalariada - estes nos limites de 20 a 50 hectares.

Nos estabelecimentos acima de 50 hectares e até 500 hectares, estaria, possivelmente, dentro das condições brasileiras, o campesinato rico ou a exploração agrícola de caráter capitalista. Estes utilizam, regulamente, mão de obra assalariada e empregam processos de produção de nível técnico mais elevado.

A propriedade latifundiária (do tipo feudal e do tipo aburguesado) estaria, no Brasil, na faixa de estabelecimentos de área superior a 500 hectares. Aí a proporção da terra explorada por conta do proprietário territorial é insignificante e a parte inexplorada pelo proprietário da terra, que ocupa extensões imensas, ou é cedida sob diferentes categorias de renda, desde as formas pré-capitalistas (renda-trabalho, renda-produto e renda-dinheiro) até as formas capitalistas (arrendamento do tipo mais 
moderno, com pagamento em dinheiro e inteira autonomia do produtor); ou permanece sem nenhuma utilização.

$\mathrm{Na}$ frente da luta de classe contra os restos do feudalismo e contra o latifundismo, alinham-se, de um lado, uma enorme massa de milhões de camponeses semifeudais e camponeses pequeno-burgueses e burgueses, massa esta de composição heterogênea, mas ligada entre si por interesses comuns quando se trata de varrer os restos pré-capitalistas, de libertar-se da coação do monopólio latifundiário e de desenvolver as relações de tipo capitalista que importem em melhorar suas condições de vida. De outro lado, há não mais de 70 mil latifundiários, semifeudais uns, semicapitalistas outros, os quais concentram em suas mãos 144 milhões de hectares de terra, isto é, uma minoria que representa apenas $3,5 \%$ do total de estabelecimentos rurais e que detém mais de $60 \%$ da área agrícola.

\section{A frente de luta contra o imperialismo}

A terceira frente ou a terceira forma da luta de classe no campo é ainda mais ampla do que as duas primeiras e baseia-se nas aspirações nacionais a romper os laços de dependência com os monopólios estrangeiros, laços que tornam a opressão feudal ainda mais dolorosa para as massas do campo.

A agricultura semifeudal do Brasil não é uma agricultura semifeudal qualquer: tem uma peculiaridade histórica que a distingue da que existia, por exemplo, nos países imperialistas como a Rússia czarista ou o Japão do começo deste século. Esta peculiaridade histórica é o caráter dependente, semicolonial de nossa economia agrária.

Por isso, ao investigarmos as condições da agricultura brasileira, não podemos menosprezar o fato de que ela é uma agricultura semifeudal de um tipo peculiar, baseada na monocultura de exportação, implantada e ainda mantida sob determinadas condições e determinadas limitações impostas segundo os interesses de grupos econômicos estrangeiros.

Os vínculos semicoloniais de nossa agricultura semifeudal não constituem uma abstração, mas, sim, têm existência material e pertencem a uma categoria econômica ainda muito pouco estudada em nosso país. Esta categoria econômica é o sistema do capital comprador.
O sistema do capital comprador é o conjunto de relações econômicas que atua, quer na produção, quer na distribuição dos produtos destinados ao mercado exterior. Para que as relações econômicas de tal natureza tenham existência material, elas exigem uma rede de empresas e de agentes cuja função, em última análise, é extrair, por processos extorsivos de coação econômica e extraeconômica, inclusive pelos processos da acumulação primitiva, a maior parte possível da mais-valia e do produto dos camponeses trabalhadores.

Existem em nosso país essa rede de empresas e de agentes do imperialismo?

A nossa realidade mostra que essa rede existe. Nela podemos incluir os monopólios da moagem do trigo (Bung Born, etc.), os frigoríficos (Armour, Anglo, etc.), os compradores e exportadores de fumo (Souza Cruz, etc.), os compradores e exportadores de algodão, amendoim, etc. (Sambra, Anderson Clayton, etc.), os compradores e exportadores de café (Standard Brands, American Coffee, etc.). Mas o sistema comprador também abrange agentes internos, empresas formalmente nacionais que agem por conta dos monopólios estrangeiros.

Se fizermos um rápido exame retrospectivo de nossa economia agrária, verificaremos que essa rede se estendia, até bem pouco, a um outro produto que liderou por muito tempo nossas exportações - o açúcar. Quando a distribuição desse produto passou, fundamentalmente, do mercado externo para o mercado interno, o sistema do capital comprador, no que se refere à economia açucareira, foi eliminado.

Tal acontecimento - que a muitos parece de menor importância teve grande significação nas transformações operadas na economia açucareira, e contribuiu decisivamente para abrir caminho a uma série de reformas burguesas, as quais encontraram sua expressão legal no estatuto da lavoura canavieira (regulamentação das relações entre produtores de cana e usineiros, entre trabalhadores do campo e fabricantes de açúcar, limitação da renda da terra, eliminação nos contratos de trabalho de algumas formas de prestação pessoal, etc.).

Dir-se-á que essas transformações, muitas das quais não tiveram cunho revolucionário, mas cunho reformista, resultaram numa piorada situação da massa dos camponeses, o que é uma verdade. Mas só os 
idealistas, os economistas românticos e os populistas podem ignorar que a penetração do capitalismo no campo, principalmente pela via do reformismo, da conciliação com o feudalismo, cria mercado interno à custa da miséria da população rural trabalhadora. Os marxistas não podem ignorar esse imperativo histórico.

Em muitas áreas rurais brasileiras, o sistema do capital comprador (empresas, agentes diretos e indiretos dos monopólios imperialistas principalmente norte-americanos) exercem sobre os camponeses uma opressão maior do que a opressão exercida pelos latifundiários. Em outras áreas, o sistema associa, combina e entrelaça de tal modo os interesses do capital comprador com os interesses dos latifundiários que não será possível separar fisicamente uns dos outros.

Todos esses aspectos peculiares de nossa agricultura semifeudal fazem convergir nossas atenções para a frente principal da luta no campo que é a frente anti-imperialista.

E, embora aqui não tenham sido examinados senão alguns desses aspectos e haja a respeito ainda muito a dizer, a pesquisar e a concluir, já nos é possível avaliar sua importância e medir a gravidade da subestimação do fator nacional no campo.

Entre as tarefas específicas compreendidas na esfera da luta antiimperialista no campo, podem ser lembradas as seguintes: a) luta contra o aviltamento dos preços, nos mercados mundiais, dos nossos produtos de exportação; b) luta contra os contratos draconianos e todas as demais formas usurárias e espoliadoras de compra de produtos agropecuários; c) luta contra as condições monopolísticas de compra e venda de produtos agrícolas ou de produtos fornecidos à agricultura, por parte de empresas estrangeiras e seus agentes; d) luta pela nacionalização do comércio exterior.

\section{IVAN RIBEIRO: A Agricultura e o Capitalismo no Brasil ${ }^{1}$}

Durante um longo período, mas sobretudo a partir da segunda metade dos anos 50, as forças progressistas brasileiras consideraram a estrutura da propriedade da terra - marcada pelo binômio latifúndio/minifúndio - como um obstáculo ao desenvolvimento do capitalismo. Em outras palavras, o latifúndio não capitalista seria um obstáculo objetivo à livre expansão das forças produtivas. A eliminação desse obstáculo era apresentada como uma condição necessária para que a sociedade brasileira avançasse no caminho de uma revolução nacional e democrática. Nesse contexto, falava-se em contradição entre a burguesia nacional, industrial e comercial, interessada na expansão de seus negócios no país, e o setor latifundiário, o qual, por seu imobilismo e atraso, limitaria essa expansão. ${ }^{2}$

O corolário disso era a reivindicação de uma reforma agrária mal definida sob muitos aspectos, mas claramente expressa pela palavra de ordem "a terra para os que nela trabalham". Sem entrarmos por enquanto em detalhes, podemos dizer que o tipo de reforma agrária que era então proposto aproximava-se de chamada "via americana" da revolução agrária burguesa, ${ }^{3}$ ou seja, implicava a transformação do camponês dependente (sob múltiplas formas de dependência) do latifúndio em proprietário das terras em que trabalha, empregando técnicas de produção mais avançadas e impulsionando assim a modernização capitalista da economia. Devemos observar que um dos aspectos desse tipo de reforma agrária, considerada corretamente como a mais revolucionária, seria a eliminação da base econômica de uma das classes sociais mais retrógradas da sociedade brasileira: os latifúndios.

Em resumo, pode-se dizer que a reforma agrária do tipo proposto teria sido um dos aspectos da revolução nacional e democrática que levaria

\footnotetext{
${ }^{1} \mathrm{O}$ presente ensaio foi publicado originalmente em francês, sob o pseudônimo de Cláudio Barros, em Études Brésiliennes (ano 1, nº 2, julho de 1975).

${ }^{2}$ A outra contradição, a que opõe a Nação ao imperialismo, não será objeto de atenção específica neste artigo

3 A expressão "via americana" é empregada aqui na acepção de Lênin. Ver Programme agraire de la social-démocratie dans la révolution russe de 1905-1907, Moscou, Ed. Du Progrès, 1962, p. 33
} 
a um novo estágio de desenvolvimento das forças produtivas na economia brasileira e, por conseguinte, abriria uma nova fase de contradições entre essas forças produtivas e as relações de produção capitalistas, o que, por sua vez, esboçaria novas perspectivas de luta pelo socialismo no Brasil.

A história dos últimos vinte anos não confirmou a maioria dessas análises. Em primeiro lugar, a existência do latifúndio não impediu que o modo de produção capitalista continuasse a se reforçar e que elevados níveis de crescimento do Produto Interno Bruto fossem atingidos em determinados anos. Em segundo lugar, se as contradições entre a burguesia nacional industrial e comercial e o setor dos latifúndios provocaram certas dificuldades, jamais se revestiram de caráter explosivo e nem mesmo podem ser consideradas com o aspecto dominante do conjunto das relações entre esses setores no curso dos últimos vinte anos. Finalmente, podemos notar que um importante setor - o determinante - dos latifúndios não pode mais ser considerado como atrasado e estacionário, já que aparece agora como um setor capitalista no sentido pleno do conceito.

As causas da inadequação de algumas previsões foram muito pouco analisadas, até hoje, pela esquerda brasileira. Assim, o objetivo principal destas notas é precisamente o de introduzir alguns elementos que permitam avaliar as razões que conduziram a previsões erradas, bem como o de apontar algumas das consequências que essas previsões tiveram no terreno da tática e da estratégia revolucionária brasileira, em particular no campo.

Sem ter a pretensão de esgotar o tema, acreditamos que pelo menos três fatores foram determinantes:

I) a falta de uma análise macroeconômica baseada num modelo das relações intersetoriais na agricultura;

II) a nova etapa do imperialismo;

III) a má compreensão do mecanismo de evolução capitalista da economia brasileira e, especificamente, do sistema agrícola.

Os pontos I e II podem ser considerados, pelo menos em parte, como resultantes da insuficiência analítica da esquerda brasileira. Quanto ao ponto II, a nova etapa do imperialismo, ele assume historicamente um caráter objetivo: em dado momento, poderia ter sido seguido um caminho diferente, mas esse caminho foi politicamente derrotado.

\section{Relações intersetoriais na economia brasileira}

Por volta de meados dos anos 50, a opinião dominante era a de que uma crise de realização seria inevitável na economia brasileira se o mercado agrícola não se "abrisse" aos produtos industriais. Pensava-se também que o afluxo de mão de obra barata para os setores não agrícolas (segundo o exemplo de alguns modelos clássicos de desenvolvimento capitalista) era indispensável para atingir um nível satisfatório de acumulação de capital na economia; a transferência de capital dos setores agrícolas para os outros setores da economia atuaria no mesmo sentido. Acreditava-se, finalmente, que a oferta inelástica de produtos alimentícios e de matérias-primas era o "núcleo duro" que originava as tensões inflacionárias que afetavam a economia brasileira.

A vida demonstrou que a permanência do "fechamento" do mercado das regiões rurais e agrícolas aos produtos industriais não impediu o desenvolvimento do capitalismo no Brasil. E que, por conseguinte, as pretensas contradições objetivas entre o setor industrial, dinâmico e modernizador, e o latifúndio, estagnado e atrasado, não atingiriam o nível esperado.

O exagero do papel negativo que a "não abertura" do mercado rural teria para a produção industrial pode ser atribuído aos seguintes fatores:

a) Subestimação da demanda existente nos setores minoritários da população de alta renda. Num país com a dimensão demográfica do Brasil, a demanda de tais setores tem uma importância econômica não negligenciável. Em certo sentido, pode-se dizer que, durante uma certa etapa, a demanda desses setores (cerca de $20 \%$ da população) pôde compensar a não participação de mais de $50 \%$ da população brasileira (que, em 1970, tinham uma renda per capita anual inferior a 100 dólares) no mercado de bens industriais. Paralelamente, é preciso reconhecer que apesar de suas limitações em termos absolutos e de sua concentração em duas regiões (Sul e Sudeste), houve uma nítida expansão da demanda do setor agrícola no que se refere a tratores, arados, fertilizantes, inseticidas, além de alguns bens de consumo. Assim, é impossível dizer que o mercado agrícola permaneceu totalmente fechado durante esse período.

b) Não se atribui a devida importância às diferentes possibilidades de expansão e de criação de "novos" mercados no contexto de uma economia 
capitalista, tais como o déficit orçamentário, as subvenções, os subsídios fiscais, as vendas a crédito, a propaganda de massa etc.

c) Pouca atenção foi dada ao fato de que, numa economia capitalista, o mercado interno cresce mais em função da produção de bens de capital (Setor I) do que a produção de bens de consumo (Setor II). Isso não significa que a produção de bens de capital seja independente da produção de bens de consumo, mas sim que o ritmo de crescimento da primeira é mais rápido e sua dinâmica é relativamente autônoma em face da dinâmica do setor II. ${ }^{4}$ Por conseguinte, mesmo quando a demanda de bens de consumo está "congelada", há ainda uma certa margem de dinamismo, baseada nas indústrias que "produzem máquinas para produzir máquinas que produzem máquinas” (segundo a expressão de Tugan-Baranovski).

No campo das demais relações entre a agricultura e os setores não agrícolas da economia é possível constatar que a passagem da mão de obra dos setores rurais para os setores urbanos teve sua importância diminuída, isso resultou do fato de que a utilização de técnicas de produção com composição orgânica do capital muito elevada (uma característica do processo de substituição de importações numa situação de dependência) fez com que o processo de acumulação do capital fosse relativamente independente da existência de um "exército industrial de reserva". A constatação disso não significa negar que os salários de algumas categorias de operários urbanos (como, por exemplo, os da construção civil) tenham sido rebaixados em função da concorrência de mão de obra proveniente do campo.

Pode-se também constatar que as tensões inflacionárias provocadas pela insuficiência estrutural da oferta agrícola tiveram uma importância menos acentuada que a prevista. Isso se deveu, em primeiro lugar, ao fato de que o perfil da demanda urbana de bens de origem agrícola se tornou mais "sofisticado", ou, em outras palavras, os setores de renda mais alta passaram a consumir relativamente menos alimentos (ou alimentos mais "sofisticados") e mais produtos industriais. A demanda de matérias-primas de origem agrícola registrou igualmente uma contração, por causa da expansão da produção de matérias-primas sintéticas. E, em segundo lugar, o feito inflacionário da oferta agrícola foi exagerado. O setor agrícola -

${ }^{4}$ Sobre esse problema, ver o interessante trabalho de Lênin, The development of capitalism in Rússia, Moscou, Progress Publishers House, 1964, p. 53-57. constituindo uma fonte de alimentação para os que formam o que entre nós se chama de "frente pioneira" (a grande massa de camponeses que ocupam terras sem títulos de propriedade e outros tipos de desbravadores de terras virgens), e fornecendo um excedente para os centros urbanos próximos teve subestimadas suas possibilidades de extensão.

A análise da agricultura brasileira negligenciou também o setor da pequena exploração agrícola (inclusive os minifúndios), que produzia o mínimo necessário para garantir a própria subsistência, ainda que em terras precárias, permitindo assim que sua demanda de alimentos não entrasse em concorrência com a dos setores urbanos.

Em suma, podemos dizer que, em função do conjunto dos fatores considerados acima, o setor agrícola - no que se refere às relações intersetoriais - teve um papel muito diverso do que o que lhe era atribuído pela esquerda brasileira no anos 50 .

\section{A nova etapa do imperialismo}

Um outro elemento a dar nova dimensão ao papel da agricultura no desenvolvimento do capitalismo no Brasil foi a nova etapa da dominação imperialista, iniciada a partir dos anos 50 e que pode ser caracterizada pelo fenômeno hoje conhecido como internacionalização do mercado interno.

Os centros nevrálgicos do imperialismo chegaram à conclusão de que a forma de exploração baseado na exportação de produtos manufaturados e na importação de matérias-primas e produtos agrícolas estava superada, como consequência de três fenômenos fundamentais:

- $\mathrm{O}$ avanço nacionalista-populista que ganhava corpo em certos países do mundo subdesenvolvidos;

- A intensificação da concorrência interimperialista para conquistar o mercado interno dos países subdesenvolvidos; e

- $\mathrm{O}$ fato de que a rentabilidade dos investimentos diretos nos países de origem.

Assiste-se assim ao surgimento de uma nova etapa, cujo traço essencial é a participação direta no processo de industrialização e de expansão do mercado interno que se ia criando em determinados países subdesenvolvidos. 
As consequências dessa nova etapa são múltiplas. Em primeiro lugar, ela levou, em certos países, à derrota das correntes nacionais-populistas que haviam elaborado projetos de industrialização onde a burguesia nacional e o Estado desempenhavam um papel fundamental. Em alguns casos, esses projetos chegaram a ser dominantes do ponto de vista político, como na Argentina (Perón), na Guatemala (Arbenz) e no Brasil (Vargas). Com a derrota do projeto nacional-populista, um novo tipo de desenvolvimento capitalista na periferia se consolidou: o desenvolvimento associado. Sem entrar na análise detalhada de importantes aspectos políticos dessa nova etapa, gostaríamos de sublinhar que, no terreno econômico, o processo de internacionalização do mercado interno se processa em ritmo acelerado. Em outras palavras: o fortalecimento da industrialização dos países subdesenvolvidos sob a égide das grandes firmas multinacionais transportou para fora desses países os centros de decisão no que se refere à produção (quantidade e qualidade), aos preços e à distribuição do produto (mercados). Desse modo, o mercado interno, doméstico, começa a fazer parte do mercado mundial.

Os efeitos dessa nova dimensão do mercado interno - agora internacionalizado - sobre a agricultura foram consideráveis, limitando ainda mais o alcance da "abertura" do mercado agrícola à produção industrial. Numa etapa subsequente, a internacionalização do mercado interno atingiu até mesmo o setor agrário, fazendo com que o comportamento da produção agrícola se relacione diretamente com as decisões dos grandes centros financeiros do mercado internacional desses produtos (as bolsas de Chicago e de Londres).

No caso brasileiro, a nova situação em que se desenvolve a agricultura - ou, pelo menos, o setor capitalista dela - levou, antes de mais nada, a uma diversificação da estrutura das exportações agrícolas, com o enfraquecimento relativo do café e o fortalecimento de produtos como o açúcar e a soja. Por outro lado, quando os agricultores capitalistas constatam a extrema sensibilidade de seus lucros às manobras especulativas do mercado mundial de produtos agrícolas, começam a exercer um novo tipo de pressão sobre o Estado brasileiro, ao mesmo tempo em que surgem novos tipos de contradição entre os interesses da agricultura e os da indústria. (Uma ilustração disso são os choques ocorridos entre os ministros da Agricultura e Fazenda durante o Governo Médici).
Se levarmos em conta tais aspectos, podemos supor que a agricultura desempenha um papel cada vez mais importante no processo de desenvolvimento associado da economia brasileira, embora esse continuese apoiando, como o caso até hoje, na crescente industrialização.

\section{O modelo de transição ao capitalismo no Brasil}

Em seu prefácio a uma obra coletiva sobre a passagem do feudalismo ao capitalismo, Maurice Dobb afirma que "o estudo da forma (ou das formas) através das quais o capitalismo surge do sistema social que o precedeu é pertinente, para não dizer essencial, à compreensão do capitalismo atual."

No Brasil, a forma específica, o modelo de evolução do capitalismo, é um tema muito pouco estudado. E, se estamos de acordo com a observação de Dobb, somos levados a pensar que muitos dos erros de análise do capitalismo brasileiro atual devem-se à exiguidade dos nossos conhecimentos sobre os caminhos seguidos por esse modo de produção no processo de sua consolidação.

Tendo em conta os limites destas notas, indicaremos em seguida apenas alguns problemas que, a nosso ver, merecem um estudo mais aprofundado.

Pensamos que o melhor modo de abordar a análise dos caminhos de desenvolvimento seguidos pelo capitalismo é o que Marx apresenta no Livro III de $O$ capital. Segundo Marx, a transição do feudalismo ao capitalismo pode assumir duas formas principais:

- O produtor torna-se comerciante e capitalista, é esse o caminho verdadeiramente revolucionário; e

- O comerciante estabelece o controle direto sobre a produção: mesmo sendo historicamente um elemento progressista, esse caminho não pode, por si só, contribuir para a superação do antigo modo de produção, e, mais que isso, tende a conservá-lo como uma pré-condição. ${ }^{6}$

\footnotetext{
${ }^{5}$ Vários autores, La transición del feudalismo al capitalismo, Madri, Ciência Nueva, 1968, p. 10. ${ }^{6}$ K. Marx, O Capital, Moscóu, Foreign Languages Publishing Home, 1962, III, p. 329.
} 
O historiador japonês Takahashi, utilizando a metodologia indicada por Marx, ilustrou historicamente esses dois modelos de desenvolvimento do capitalismo. Examinando os casos da Inglaterra e da França, Takahashi sublinha que "nesses países, a propriedade feudal da terra e a servidão ou se desintegraram no curso do processo de desenvolvimento econômico, ou foram estruturalmente destruídas, e de modo categórico, pela revolução burguesa. Essa última, ao permitir a independência e a ascensão dos pequenos produtores mercantis, bem como sua diferenciação, liberou entre eles as forças que conduziram ao desenvolvimento do capitalismo". E Takahashi prossegue: "Ao contrário, no Japão e na Prússia, a organização da propriedade feudal da terra conservou-se intacta, e a classe dos camponeses livres, bem como a dos burgueses médios, não se desenvolveu. Dado que o capitalismo foi forçado a crescer nesse terreno, com base numa fusão com o absolutismo e não através de um conflito com o mesmo, a formação do capitalismo ocorreu de forma oposta à da Europa Ocidental, ou seja, ocorreu essencialmente como um processo de transformação do capital comercial, com base no trabalho a domicílio, em capital industrial".

Por outro lado, os dois caminhos de evolução agrária burguesa apontados por Lênin - a "via prussiana" e a "via americana" - estão de certo modo relacionados com as duas vias gerais especificadas por Takahashi. A via prussiana representa a possibilidade de continuação do desenvolvimento de tipo burguês sob a égide da grande propriedade feudal, que se torna gradualmente mais burguesa e substitui pouco a pouco os procedimentos feudais por procedimentos burgueses.

A "via americana" implica o desenvolvimento de tipo burguês sob a égide da pequena exploração camponesa, pelo caminho revolucionário, eliminando do organismo social essa "excrescência" representada pelos grandes proprietários feudais, para em seguida se desenvolver livremente, seguindo o caminho da exploração capitalista. ${ }^{8}$

A partir desse quadro conceitual, como caracterizar a evolução do capitalismo e, em particular, a evolução agrária capitalista no Brasil?

Os aspectos fundamentais da história econômica brasileira parecem indicar que o modelo de transição para o capitalismo no Brasil aproxima-se

\footnotetext{
${ }^{7}$ M. Dobb, in: La transición, cit., p. 105.

${ }^{8}$ Lênin, Programme agraire, cit. p. 32-33.
}

mais da "via prussiano-japonesa". Dissemos "aproxima-se" com a intenção de mostrar que o caminho seguido pelo Brasil não pode ser inteiramente identificado com o daqueles dois países. A primeira diferença essencial provém do fato de que a formação socioeconômica existente no Brasil (a comunidade indígena primitiva) encontrava-se num estágio muito inferior de desenvolvimento em face do modo de produção transplantado pelo colonizador português. O resultado é que não se deu o processo de assimilação do modo de produção indígena pelo que foi trazido pelos colonizadores com base num processo endógeno de evolução econômica; ao contrário, assistiu-se a uma marginalização geográfica do modo de produção indígena (que sobreviveu no interior da colônia), ou à sua destruição pela força militar na zona do litoral.

A ausência de um processo econômico endógeno, bem como o caráter ou sentido da colonização (o de resposta às necessidades mercantis de Portugal), ${ }^{9}$ tornaram possível e necessário que a exploração colonial tivesse como núcleo central o latifúndio. Sem ter de enfrentar estruturas econômicas e sociais preexistentes, e sendo funcional para a metrópole, o latifúndio se consolidou ao longo da história da colônia. A partir das capitanias hereditárias, nas quais os donatários tinham poderes comparáveis aos de um minissoberano, passando pelas relações híbridas feudaisescravistas do latifúndio açucareiro e cafeeiro (no contexto da dominação do capital mercantil), até chegar ao latifúndio capitalista de hoje (exportador de soja, açúcar e carne, em contato permanente com a bolsa de Chicago), pode-se constatar que o processo histórico jamais levou à necessidade de uma revolução burguesa que tivesse como objetivo suprimir o latifúndio e empreender a "via americana" de evolução agrária. Quando os setores comerciais e industriais urbanos já eram dominantes na vida política e econômica do País. O desenvolvimento do capitalismo já seguia e continuaria a seguir no futuro - um modelo mais próximo da "via prussiano-japonesa".

Apesar da importância do latifúndio para uma correta compreensão do processo de desenvolvimento do capitalismo no Brasil, é indispensável analisar o setor constituído pelas pequenas e médias propriedades agrícolas. Situadas inicialmente em torno dos centros urbanos, responsáveis por seu

${ }^{9}$ Um caráter diferente, portanto, da colonização dos Estados Unidos, onde se tratava, antes de mais nada, de começar uma "nova vida". 
abastecimento em um bom número de bens agrícolas, as pequenas e médias propriedades agrícolas vão se instalando progressivamente no território brasileiro. Juntamente com a mineração e a pecuária intensiva, as pequenas e médias explorações agrícolas foram um elemento essencial do desenvolvimento da agricultura. De resto, o peso desse setor no abastecimento da demanda urbana permitiu que o latifúndio conservasse sua estrutura tradicional: a de produtor para a exportação, bem como para a subsistência da mão de obra que empregava. Essa característica tornou possível que, nos períodos de crise e de contração das exportações, os latifúndios pudessem se concentrar em atividades de pura subsistência (economia natural), sem serem conduzidos ao fracionamento ou à desapropriação. Esse papel da pequena e da média propriedade apresenta ainda um outro aspecto que merece ser assinalado: desbravando terras virgens quase que somente através de investimentos "naturais", ou seja, do emprego intensivo de mão de obra, esses setores dispensaram a absorção de grandes recursos de capital pelo setor agrícola, tornando assim mais fácil o investimento em outros setores da economia.

A complementaridade entre latifúndio e pequena e média propriedade, bem como o papel dessas últimas na expansão da fronteira agrícola, são assim elementos indispensáveis para o estudo da transição para o capitalismo em nosso país.

Devemos ainda examinar as relações entre o latifúndio e o setor industrial. A história das políticas econômicas adotadas pelo Estado brasileiro mostra claramente a predominância dos interesses do setor latifundiário, sobremaneira na fase de produção do café. Quando a partir sobretudo dos anos 30, os interesses urbanos e industriais começam a participar ativamente do poder político, não assistimos a choques significativos entre os dois setores. $\mathrm{E}$ isso, antes de mais nada, porque uma parte do capital industrial era de origem agrícola; mas também porque as novas políticas adotadas jamais afetaram seriamente os interesses dos latifundiários. Desse modo, o processo de desenvolvimento do capitalismo se processou sem ruptura entre os dois setores.

\section{Qual reforma agrária?}

Levando em conta o conjunto dos fatores aludidos, e partindo do fato de que a transição para o capitalismo seguiu (e ainda segue), de modo aproximativo, uma via prussiana, cabe formular uma questão: seria ainda justo reivindicar uma reforma agrária do tipo "a terra para quem nela trabalha" como um dos elementos da plataforma da revolução brasileira em sua atual etapa? Uma reforma desse tipo seria ainda progressista e revolucionária, ou já estaria ultrapassada?

A resposta a tais questões poderia começar com a citação de uma passagem de $O$ Capital sobre a Alemanha de 1867: "Além das misérias modernas, somos afligidos por toda uma série de misérias herdadas, frutos da sobrevivência dos modos de produção antigos e caducos, com seu séquito de relações políticas e sociais anacrônicas" ${ }^{10}$ Referindo-se à Alemanha, Marx indicava um país onde a transição para o capitalismo seguira a "via prussiana", ou seja, a via menos revolucionária. Não é necessário repetir que o Brasil seguiu um caminho similar e que, por conseguinte, o desenvolvimento do capitalismo foi marcado pela coexistência permanente entre as "misérias modernas" e as "misérias antigas".

Consideramos que uma reforma agrária poderia desempenhar ainda um papel fundamental na liquidação de todos esses anacronismos. Isso não significa, contudo, que a não realização dessa reforma agrária levaria o desenvolvimento do capitalismo no Brasil a um impasse. Por outro lado, uma eventual reforma agrária não poderia se limitar a dar a terra a quem nela trabalha. No caso do setor capitalista da agricultura, caracterizado pela existência do trabalho assalariado, não se justifica a criação agora de uma "via americana". O que importa, nesse caso, é ampliar a luta por novas condições de trabalho, pela aplicação da legislação trabalhista, pela formação de sindicatos etc.

Quanto ao setor dos minifúndios e da pequena propriedade familiar camponesa, que emprega sobretudo mão de obra familiar e que absorve poucos produtos intermediários industriais ${ }^{11}$ - e esse setor representa, no campo, a sequela das relações políticas e sociais anacrônicas mencionadas

${ }^{10} \mathrm{~K}$. Marx, $O$ Capital, cit., Prefácio à primeira edição inglesa.

11 Segundo o censo agrícola de 1960 , esse setor representava $2 / 3$ do número total de explorações, $1 / 2$ do pessoal empregado, $20 \%$ da superfície total e $40 \%$ da área cultivada, 
por Marx -, parece-nos claro que a plataforma revolucionária deve propor a luta por uma reforma agrária que leva a um tipo de agricultura mais próximo da "via americana". As terras a serem incorporadas a tal setor seriam fundamentalmente as do latifúndio atrasado, não capitalista, que seria assim eliminado. Deve-se sublinhar que não se trata de criar uma nova economia camponesa (pois essa já existe), mas de tornar possível a emergência de novas condições de desenvolvimento para um setor agrícola que, ainda hoje, não pode ser considerado como capitalista. E, precisamente porque ele ainda não é capitalista, a reforma agrária não levaria a uma regressão na formação econômico-social existente, mas sim a um progresso.

Neste ponto de nossa exposição, poderíamos levantar uma série de questões. Uma reforma agrária que atingisse o setor atrasado do latifúndio é politicamente viável? O outro setor não se juntaria imediatamente ao campo dos que lutam contra a "subversão"? É indiscutível que uma reforma agrária desse tipo seria difícil, mas não impossível. Não seríamos arrastados num processo que levaria, a longo prazo, à constituição de novos minifundistas e de novos latifundiários? Talvez. Mas qual seria a alternativa? Não ter um programa agrário para a atual etapa da revolução? Limitar esse programa às reivindicações dos assalariados agrícolas, deixando de lado o setor camponês? Ou, então, apresentar desde já um programa agrário que implique uma revolução socialista? Consideramos que a solução correta seria uma reforma agrária do tipo acima proposto, seguida, se possível, pela modificação das condições externas (créditos, comercialização, fornecimento de insumos etc.), o que garantiria melhores condições de desenvolvimento para o setor dos camponeses, pequenos e médios, e limitaria o gigantismo dos latifúndios capitalistas.

A justificativa e o fundamento desse tipo de reforma agrária baseiamse no caráter da economia familiar camponesa. Esse problema foi profundamente subestimado no Brasil. Isso se deve, em parte, ao fato de que a agricultura no Brasil foi sempre dominada pelo latifúndio. Mas essa incompreensão baseia-se também em preconceitos que devem ser superados.

Em primeiro lugar, temos de reconhecer que se trata de um problema complexo. Para nos convencermos disso, basta encarar a experiência dos países socialistas, onde a tentativa de "queimar etapas" e de integrar a economia familiar camponesa em unidades de maior ou menor caráter socialista resultaram sempre em fracassos nos kolkhozes soviéticos e nas comunas populares chinesas representam uma espécie de compromisso possível entre a atividade coletiva e a atividade individual dos camponeses na etapa atual de transição para o socialismo. Mas há também o caso de países socialistas (como, por exemplo, a Polônia), onde a unidade familiar camponesa ${ }^{12}$ é a forma dominante da propriedade e da exploração agrícola - inserida, decerto, no contexto de condições externas já socialistas.

É certo que a América Latina apresenta uma situação muito específica em comparação com a Europa, o que confere à forma familiar camponesa latino-americana características muito diferentes. Essa especificidade não foi devidamente estudada na América Latina e, em particular, no Brasil. ${ }^{13}$

O ponto de partida para esse estudo poderia ser a exploração dos materiais originários da escola neopopulista russa (cuja figura mais expressiva era Chayanov),${ }^{14}$ materiais que foram reexaminados, à luz do marxismo, pelo economista agrário polonês J. Tepich. ${ }^{15}$

Um estudo desse tipo, que escapa ao objetivo deste artigo, mostraria certamente a insuficiência da caracterização da economia familiar camponesa como parte integrante da pequena burguesia mercantil.

Revelaria, igualmente, o equívoco de considerar como "concessões" as atitudes das forças revolucionárias diante desses setores. Ao contrário, por se tratar de um aliado potencial na etapa da revolução democrática e anti-imperialista, e, também, de um "companheiro de viagem" durante um longo período da construção do socialismo (como o demonstra a história dos países socialistas), o camponês parcelar é um elemento importante no processo revolucionário latino-americano. Identificá-lo como pertencente ao setor capitalista e limitar a ação revolucionária aos assalariados agrícolas e aos minifundiários implicaria restringir as bases revolucionárias no campo e levaria a sérios problemas no curso das próximas etapas da revolução.

\footnotetext{
12 O termo "camponês" estabelece a diferença entre esse tipo de exploração e a unidade familiar industrial (característica de países como a República Federal da Alemanha, Dinamarca e a Holanda), que utiliza insumos industriais em larga escala.

${ }^{13}$ A análise dessa especificidade foi uma das principais preocupações teóricas de Ivan Ribeiro. Ver, nesse sentido, Ivan de Otero Ribeiro, "A importância da exploração familiar camponesa na América Latina, in: Temas, São Paulo, no 4, 1978, p. 143-159, que reproduz o trabalho por ele apresentado num simpósio realizado em Uppsala, Suécia, em novembro de 1977.

${ }^{14}$ Chayanov, The theory of peasant economy, Homewood, III., Richard D. Irwin Inc., 1966. ${ }^{15}$ J. Tepich, Marxisme et agricultures le paysan polonais, Paris, Armand Collin, 1973.
} 


\section{III - PARTE APÊNDICE}

\section{DeClaração Sobre a Política do Partido Comunista Brasileiro ${ }^{1}$}

Os documentos do XX Congresso do PCUS motivaram nas fileiras do nosso Partido intensa discussão, no curso da qual foram submetidos à crítica os graves erros de caráter dogmático e sectário da orientação política do Partido.

O exame destes erros e a necessidade de superá-los levaram o Comitê Central do PCB a traçar uma nova orientação política, que é exposta na presente declaração. Ao fazê-lo, o Comitê Central considerou a experiência passada do Partido e as modificações essenciais ocorridas na situação do Brasil e do mundo.

O Comitê Central espera que, no processo de sua aplicação prática, a política aqui traçada seja submetida à comprovação e enriquecida pela experiência do Partido e do povo brasileiro.

\section{I - O processo de desenvolvimento econômico do Brasil}

Modificações importantes têm ocorrido, durante as últimas décadas, na estrutura econômica que o Brasil herdou do passado, definido pelas seguintes características: agricultura baseada no latifúndio e nas relações pré-capitalistas de trabalho, predomínio maciço da produção agropecuária no conjunto da produção, exportação de produtos agrícolas como eixo de toda a vida econômica, dependência da economia nacional em relação ao estrangeiro, através do comércio exterior e da penetração do capital monopolista nos postos-chave da produção e da circulação.

${ }^{1}$ Esta resolução do Comitê Central do PCB foi publicada no jornal Voz Operária, 22 de março de 1958 .
Nos quadros dessa estrutura atrasada, foi-se processando um desenvolvimento capitalista nacional, que constitui o elemento progressista por excelência da economia brasileira. Este desenvolvimento inelutável do capitalismo consiste no incremento das forças produtivas e na expansão, na base material da sociedade, de novas relações de produção, mais avançadas.

Por sua própria natureza e ainda por se chocar com a resistência de elementos econômicos atrasados e sofrer a pressão do imperialismo, o desenvolvimento capitalista nacional vem-se realizando num ritmo bastante desigual, se bem que tenha se acelerado nos últimos vinte anos.

O desenvolvimento capitalista nacional já trouxe resultados que modificaram sensivelmente a vida econômica e social do país. Assim é que foi construído no Brasil um parque industrial, que abastece o mercado interno da quase totalidade de artigos de consumo comum. A indústria de meios de produção elevou a sua participação de 20 a $33 \%$ no conjunto da produção industrial, entre os anos de 1939 a 1956. Num prazo relativamente breve, de 1944 a 1956, o volume físico da produção industrial total foi duplicado. Surgiu e se fortaleceu no setor da indústria pesada um capitalismo de Estado de caráter nacional e progressista, que abrange empresas poderosas como a Petrobrás e a Companhia Siderúrgica Nacional Embora mais lentamente, também na agricultura vem-se desenvolvendo o capitalismo, que se traduz no crescimento do número de assalariados e semiassalariados, bem como na multiplicação da quantidade de máquinas e instrumentos agrários. Ampliou-se de modo acentuado o mercado interno, sendo que o volume do comércio de cabotagem entre 1921 e 1955 aumentou de cinco vezes.

Em consequência do desenvolvimento capitalista, cresceram os efetivos do proletariado industrial e aumentou o seu peso específico no conjunto da população. Enquanto esta duplicou de 1920 até hoje, o número de operários industriais aumentou de sete vezes no mesmo período, passando de 275.000 a cerca de 2 milhões. Simultaneamente, surgiu e se fortaleceu cada vez mais uma burguesia interessada no desenvolvimento independente e progressista da economia do país.

O desenvolvimento capitalista, entretanto, não conseguiu eliminar os fatores negativos, que determinam as características do Brasil como país subdesenvolvido. Ao tempo em que se incrementam as forças produtivas e progridem, as novas relações de produção capitalistas, conservam-se em 
vastas áreas as relações atrasadas e permanece a dependência diante do imperialismo particularmente o norte-americano.

Com a penetração do capitalismo na agricultura, combinam-se, em proporção variável, os métodos capitalistas à conservação do monopólio da terra e das velhas relações semifeudais, o que permite um grau mais elevado de exploração dos trabalhadores do campo. O Brasil continua a ser um país de grande concentração latifundiária: em 1950, os estabelecimentos agrícolas com 500 hectares e mais constituíam 3,4\% do número total de estabelecimento e abrangiam $62,3 \%$ de toda a área ocupada. As sobrevivências feudais obstaculizam o progresso da agricultura, que se realiza, em geral, lentamente, mantém o baixíssimo nível de vida das massas camponesas e restringem de modo considerável as possibilidades de expansão do mercado interno. As sobrevivências feudais são um dos fatores que acentuam a extrema desigualdade de desenvolvimento das diferentes regiões do país, especialmente entre o sul e parte do leste, que se industrializam, e o resto do país, quase inteiramente agrário.

Apesar de detida sua penetração em algumas importantes esferas da economia brasileira, o imperialismo continua a dominar posições-chave em ramos fundamentais. Esta penetração é realizada em elevado grau sobretudo pelos monopólios norte-americanos que, a partir da segunda guerra mundial, alcançaram o predomínio absoluto sobre os seus competidores. Os investimentos diretos norte-americanos aumentaram de 193,6 milhões de dólares, em 1929, para 1.107 milhões de dólares em 1955. Cerca de 60\% dos financiamentos estrangeiros procedem dos Estados Unidos. Mais de um terço do comércio exterior brasileiro é realizado com os Estados Unidos, que, além disso, dominam o mercado internacional de nossos principais produtos de exportação e podem, assim, fazer do comércio exterior um instrumento de controle da vida econômica e política do país.

Mantendo embora o seu predomínio, o imperialismo norte americano enfrenta no Brasil a crescente concorrência de outras potências imperialistas, principalmente da Alemanha Ocidental e da Inglaterra.

A exploração imperialista impõe pesado tributo à nação, transferindo para o exterior considerável parte do valor criado pelos trabalhadores brasileiros, o que reduz, em consequência, a taxa de acumulação capitalista no país, diminui o ritmo do seu progresso e influi no baixo nível de vida da sua população.
A independência política do Brasil sofre sérias restrições em virtude da situação de dependência econômica. À medida que a nação se desenvolve, aguça-se o seu antagonismo com o imperialismo norte americano. O desenvolvimento capitalista nacional exige cada vez mais, como seu instrumento, uma independência política completa, que se traduza numa política exterior independente e na proteção consequente do capital nacional contra o capital monopolista estrangeiro.

O processo de democratização se reflete no Parlamento. É verdade que os setores reacionários e entreguistas ainda possuem poderosas posições naquela instituição e conseguem impor decisões opostas aos interesses nacionais, a exemplo da aprovação do Acordo Militar Brasil Estados Unidos, da rejeição de uma legislação social para os trabalhadores do campo e da cassação do direito de representação parlamentar para o Partido Comunista. É igualmente inegável, porém, que vem aumentando nas sucessivas legislaturas o número de parlamentares nacionalistas e democráticos integrantes dos mais variados partidos. Isto indica o aumento da influência da burguesia nesses partidos e a utilização do voto por grandes setores das massas, particularmente do proletariado, para apoiar uma política nacionalista e democrática. Se bem que o processo eleitoral ainda esteja submetido a restrições antidemocráticas, as massas têm conseguido influir na composição do parlamento e pressionando sobre ele com a ação extraparlamentar, já o levaram a adotar decisões positivas para a emancipação nacional, a exemplo do monopólio estatal do petróleo e da política nacionalista dos minerais atômicos.

O processo de desenvolvimento capitalista e a participação da burguesia no poder do Estado se refletem também na composição do atual governo. Em decorrência da coligação de que surgiu, o governo do Sr. Juscelino Kubitschek tomou um caráter heterogêneo, com um setor entreguista ao lado de um setor nacionalista burguês.

A composição do governo do Sr. Juscelino Kubitschek é, em virtude disso, o resultado de um compromisso entre as duas alas que o integram. Este compromisso é frágil, não anula as contradições internas do governo e não impede a luta que lavra no seu seio. Apoiado nas massas, na Frente Parlamentar Nacionalista e no setor nacionalista das Forças Armadas, o setor nacionalista do governo tem influído para importantes decisões positivas. Disto são exemplos expressivos a defesa do monopólio estatal do petróleo e a 
manutenção de um clima de legalidade constitucional na vida política. Por outro lado, sob a pressão do setor entreguista e do imperialismo norteamericano, os elementos nacionalistas do governo têm sido levados a vacilações, derrotas e mesmo a graves capitulações, como foi o caso da cessão do arquipélago de Fernando de Noronha aos Estados Unidos.

As contradições existentes no seio do governo se manifestam em todas as esferas de sua atividade.

A política exterior permanece em geral caudatária do Departamento de Estado norte-americano, mas se fortalece a pressão do setor nacionalista por importantes modificações, como a exigência do estabelecimento de relações com a União Soviética e demais países socialistas.

O governo tem desenvolvido, apoiado no povo, formas nacionais e progressistas de capitalismo de Estado, a exemplo da Petrobrás e de Volta Redonda. O capitalismo de Estado vem sendo um elemento progressista e anti-imperialista da política econômica do governo, mas este ainda permite que empresas de capitalismo de Estado realizem uma política favorável ao imperialismo, como no caso dos financiamentos do BNDE ou da distribuição, pelos trustes, da energia produzida nas centrais elétricas estatais.

Enquanto toma medidas de interesse nacional, ao defender o café contra a especulação das firmas norte-americanas no mercado interno e mundial, o governo continua a propiciar inversões imperialistas à base de excepcionais privilégios, que suscitam protestos dos círculos mais representativos da burguesia. As medidas de reforma agrária não figuram sequer nos planos governamentais. A inflação e a carestia de vida continuam sendo fatores de instabilidade da economia nacional e de crescentes dificuldades para as massas.

Enquanto altera a velha estrutura econômica e cria uma nova e mais avançada, o desenvolvimento capitalista nacional entra em conflito com a exploração imperialista e a estrutura tradicional arcaica e em decomposição. Este desenvolvimento se processa através de contradições, de avanços e recuos, mas é a tendência que abre caminho e se fortalece.

\section{II - A democratização da vida política nacional}

O desenvolvimento capitalista do país não podia deixar de refletir-se no caráter do Estado brasileiro, em seu regime político e na composição do governo.

O Estado brasileiro atualmente representa os interesses dos latifundiários, dos setores de capitalistas ligados ao imperialismo, particularmente ao norte-americano, e também da burguesia interessada no desenvolvimento independente da economia nacional. Daí surgem contradições e tipos diversos de compromisso de classe no seio do próprio Estado. Os diferentes interesses de classe representados nos órgãos do Estado encontram pontos de contato e de acordo mas, ao mesmo tempo, lutam entre si para impor determinados rumos à política estatal, chegando por vezes a conflito aberto, como em agosto de 1954 e em novembro de 1955.

As forças novas que crescem no seio da sociedade brasileira, principalmente o proletariado e a burguesia, vêm impondo um novo curso ao desenvolvimento político do país, com o declínio da tradicional influência conservadora dos latifundiários. Este novo curso se realiza no sentido da democratização, da extensão dos direitos políticos a camadas cada vez mais amplas.

A democratização do regime político do país, que tomou impulso com os acontecimentos de 1930, não segue o seu curso em linha reta, mas, enfrentando a oposição das forças reacionárias e pró-imperialistas, sofre, em certos momentos, retrocessos ou brutais interrupções, como sucedeu com o Estado Novo, com a ofensiva reacionária de 1947 ou por ocasião do golpe de 1954. Mas o processo de democratização é uma tendência permanente. Por isto, pode superar quaisquer retrocessos e seguir incoercivelmente para diante. Vem-se firmando, assim, em nosso país, a legalidade democrática, que é defendida por amplas e poderosas forças sociais.

A Constituição promulgada em 1946 encerra traços reacionários que resultaram da correlação de forças existente na época de sua elaboração e expressam aspectos retrógrados da estrutura econômico-social brasileira. Ao mesmo tempo, a Constituição consagra as liberdades democráticas e os direitos sociais das massas alcançados após a derrota mundial no nazifascismo e do Estado Novo em nosso país: as liberdades de expressão, inclusive de imprensa, de reunião e de organização, o direito de greve, etc. 
As massas trabalhadoras das cidades têm obtido vitórias na justa luta pela concretização de seus direitos já consolidados em lei, como a liberdade sindical, a previdência social e outros. A democratização do país também influi, menos acentuadamente, nas zonas rurais, onde o tradicional despotismo dos grandes senhores de terra é obrigado a ceder terreno, conquanto ainda perdure. Os atentados cometidos pelos elementos reacionários do aparelho do Estado encontram a resistência cada vez mais eficiente das massas na defesa das liberdades e dos direitos constitucionais. Tudo isso explica por que, no curso da vida política recente do país, as forças nacionalistas e democráticas se colocaram ao lado da Constituição, como sucedeu a 24 de agosto de 1954 e a 11 de novembro de 1955, ao passo que as forças golpistas pró-imperialistas atentaram contra ela.

A política do governo do Sr. Juscelino Kubitschek não atende, assim, aos interesses nacionais e às aspirações das massas populares em questões essenciais, contendo, entretanto, aspectos positivos de caráter nacionalista e democrático. À medida que os aspectos negativos da atuação do governo se tornam mais evidentes, acentua-se a luta por modificações na sua composição e na sua política num sentido favorável aos interesses nacionais e populares. Esta luta é apoiada pelo setor nacionalista do próprio governo e aprofunda as suas contradições com o setor entreguista.

É na luta contra o imperialismo norte-americano e os seus agentes internos que as forças progressistas da sociedade brasileira podem acelerar o desenvolvimento econômico independente e o processo de democratização da vida política do país. Para atingir este objetivo, as forças progressistas têm interesse em defender, estender e consolidar o regime de legalidade constitucional e democrático.

\section{III - Crescem no mundo inteiro as forças da paz, da democracia e do socialismo}

$\mathrm{Na}$ situação do Brasil, no desenvolvimento de suas forças antiimperialistas e democráticas, influem poderosamente as modificações essenciais verificadas na situação internacional, sobretudo após a segunda guerra mundial.

A característica nova e principal de nossa época, o seu conteúdo fundamental, é a transição do capitalismo ao socialismo, iniciada pela
Grande Revolução Socialista de Outubro na Rússia. O socialismo ultrapassou os marcos de um só país e se transformou num sistema mundial vigoroso e florescente, que exerce influência positiva na evolução política e social de todos os povos. São enormes os êxitos econômicos e culturais dos países socialistas, e em primeiro lugar da União Soviética, que já assumiu a vanguarda em importantes ramos da ciência e da tecnologia, marchando para superar, em breve prazo histórico, o país capitalista mais adiantado, os Estados Unidos, quanto aos índices fundamentais da produção por habitante. Estes êxitos crescentes atraem para a ideia do socialismo a consciência das grandes massas de todos os continentes. Aplicando com justeza os princípios do marxismo-leninismo às condições nacionais específicas, fortalecem-se os partidos comunistas e operários de numerosos países do mundo capitalista.

O movimento comunista mundial elevou a novo nível a sua unidade. A luta da classe operária obtém grandiosas vitórias e constitui uma força decisiva na situação internacional.

Fato novo de imensa significação é o adiantado processo de desagregação do sistema colonial do imperialismo. Populações de mais de um bilhão de pessoas se libertaram do jugo colonial e alcançaram a independência política, enquanto os povos ainda submetidos aquele jugo intensificam a sua luta de libertação, colocando em situação cada vez mais difícil as potências imperialistas. Surgiu no mundo uma vasta zona de paz, que abrange os países socialistas e os países da Ásia e da África amantes da paz e promotores de uma política de defesa da sua soberania e de emancipação econômica.

A luta contra o imperialismo norte-americano, pela democracia e pela paz eleva o seu nível na América Latina. As ditaduras terroristas a serviço dos monopólios dos Estados Unidos estão sendo derrubadas, o que abre caminho para o avanço do processo democrático e emancipador. A política de chantagem guerreira praticada pelos círculos de Washington vem fracassando na América Latina, à medida que se acentua o alívio da tensão internacional.

Em consequência do impetuoso ascenso do socialismo e das vitórias do movimento de libertação nacional, acelerou-se o processo de debilitamento e decomposição do imperialismo. Não só se reduziu drasticamente a área do seu domínio, como se agravaram as contradições 
entre os países imperialistas e dentro de cada um deles. Aumentam as dificuldades econômicas nos Estados Unidos, onde a produção vem caindo, enquanto cresce o número de desempregados, o que delineia uma perspectiva de crise econômica.

O imperialismo norte-americano é o centro da reação mundial. Segue uma política de atentados contra a soberania nacional de todos os povos, de corrida armamentista e preparativos de uma terceira guerra mundial, que seria a mais terrível catástrofe para a humanidade.

As guerras de agressão continuam a encontrar terreno na existência do imperialismo e este ainda tem desencadeado bárbaros atentados contra numerosos povos. Em virtude, porém, da correlação de forças favorável ao socialismo e às forças amantes da paz, surgiu em nossa época a possibilidade real de impedir as guerras. A luta pela paz - tarefa primordial de todos os povos - tem condições para ser plenamente vitoriosa. A política consequente de coexistência pacífica praticada pela União Soviética e pelos demais países socialistas ganha a simpatia dos povos, desfaz as manobras da "guerra fria" e consegue resultados concretos no sentido do alívio da tensão internacional. A rápida cessação da agressão imperialista ao Egito mostrou mais uma vez que a causa da paz e da libertação nacional tem a seu favor forças mais poderosas do que os agentes da guerra.

As modificações na arena internacional criam condições mais favoráveis para a luta pelo socialismo, tornam mais variados os caminhos da conquista do poder pela classe operária e as formas de construção da nova sociedade. A possibilidade de uma transição pacífica ao socialismo se tornou real numa série de países.

O ascenso do socialismo, da causa da paz e do movimento de libertação nacional no mundo inteiro influi de modo positivo no crescimento das forças políticas anti-imperialistas e democráticas no Brasil.

A nova situação internacional cria condições favoráveis ao desenvolvimento econômico de nosso país, à libertação da dependência em relação ao imperialismo, à democratização da vida política nacional. Estas condições são especialmente favoráveis à aplicação de uma política externa independente e de paz, em benefício da emancipação econômica da nação. Uma política desta ordem, que muitos países do mundo capitalista já praticam, encontra o apoio de poderosas forças que atuam no cenário mundial.
Conquanto se beneficie da influência dos fatores positivos da situação internacional, o povo brasileiro é obrigado a enfrentar a pressão e os atentados do imperialismo norte-americano, que ocupa posições-chave na economia de nosso país e interfere nas questões de sua política interna e externa. Não obstante as derrotas que tem sofrido, não cessa a penetração econômica dos monopólios norte-americanos. Os círculos dirigentes dos Estados Unidos, com o apoio dos setores entreguistas, tomam medidas para vincular o Brasil aos preparativos bélicos e aos planos de uma terceira guerra mundial. Esta é a mais grave ameaça que pesa sobre a nossa pátria e contra esta ameaça tendem a unir-se todos os brasileiros favoráveis à manutenção da paz.

A luta contra o imperialismo norte-americano, pela independência nacional do Brasil, é parte integrante da luta pela paz mundial. As vitórias da causa da paz no mundo inteiro contribuem para os êxitos da luta emancipadora de nosso povo. Existem condições para derrotar a política de dependência ao imperialismo norte-americano e anular suas ameaças. A situação internacional é favorável às forças que lutam pela paz, pela emancipação nacional e pela democracia no Brasil.

\section{IV - Aprofunda-se a contradição entre a nação brasileira e o imperialismo norte-americano}

As modificações na situação econômica e política do país, bem como na situação internacional, determinam importantes alterações na disposição das forças sociais e definem o caminho para a solução dos problemas da revolução brasileira.

Como decorrência da exploração imperialista norte-americana e da permanência do monopólio da terra, a sociedade brasileira está submetida, na etapa atual de sua história, a duas contradições fundamentais.

A primeira é a contradição entre a nação e o imperialismo norteamericano e seus agentes internos. A segunda e a contradição entre as forças produtivas em desenvolvimento e as relações de produção semifeudais na agricultura. O desenvolvimento econômico e social do Brasil toma necessária a solução dessas duas contradições fundamentais.

A sociedade brasileira encerra também a contradição entre o proletariado e a burguesia, que se expressa nas várias formas da luta de 
classes entre operários e capitalistas. Mas esta contradição não exige uma solução radical na etapa atual. Nas condições presentes de nosso país, o desenvolvimento capitalista corresponde aos interesses do proletariado e de todo o povo.

A revolução no Brasil, por conseguinte, não é ainda socialista, mas anti-imperialista e antifeudal, nacional e democrática. A solução completa dos problemas que ela apresenta deve levar à inteira libertação econômica e política da dependência para com o imperialismo norte-americano; à transformação radical da estrutura agrária, com a liquidação do monopólio da terra e das relações pré-capitalistas de trabalho; ao desenvolvimento independente e progressista da economia nacional e à democratização radical da vida política. Estas transformações removerão as causas profundas do atraso de nosso povo e criarão, com um poder das forças antiimperialistas e antifeudais sob a direção do proletariado, as condições para a transição ao socialismo, objetivo não imediato, mas final, da classe operária brasileira.

Na situação atual do Brasil, o desenvolvimento econômico capitalista entra em choque com a exploração imperialista norte-americana, aprofundando-se a contradição entre as forças nacionais e progressistas em crescimento e o imperialismo norte-americano, que obstaculiza a sua expansão. Nestas condições, a contradição entre a nação em desenvolvimento e o imperialismo norte-americano e os seus agentes internos tornou-se a contradição principal na sociedade brasileira.

O golpe principal das forças nacionais, progressistas e democráticas se dirige, por isto, atualmente, contra o imperialismo norte-americano e os entreguistas que o apoiam. A derrota da política do imperialismo norteamericano e de seus agentes internos abrirá caminho para a solução de todos os demais problemas da revolução nacional e democrática no Brasil.

Para realizar a sua política de exploração e de vinculação de nosso país aos seus planos guerreiros, o imperialismo norte-americano conta com o apoio de setores de latifundiários e de setores da burguesia. Servem ao imperialismo norte-americano os latifundiários que estão ligados, por seus interesses, à exploração imperialista, numerosos intermediários do comércio exterior, os sócios de empresas controladas pelo capital monopolista norteamericano e determinados agentes de negócios bancários e comerciais.
Estes setores - minoria verdadeiramente ínfima - constituem as forças entreguistas que, dentro e fora dos órgãos de Estado, sustentam a política de dependência ao imperialismo norte-americano.

Ao inimigo principal da nação brasileira se opõem, porém, forças muito amplas. Estas forças incluem o proletariado, lutador mais consequente pelos interesses gerais da nação; os camponeses, interessados em liquidar uma estrutura retrógrada que se apoia na exploração imperialista; a pequena burguesia urbana, que não pode expandir as suas atividades em virtude dos fatores de atraso do país; a burguesia, interessada no desenvolvimento independente e progressista da economia nacional; os setores de latifundiários que possuem contradições com o imperialismo norte-americano, derivadas da disputa em torno dos preços dos produtos de exportação, da concorrência no mercado internacional ou da ação extorsiva de firmas norte-americanas e de seus agentes no mercado interno; os grupos da burguesia ligados a monopólios imperialistas rivais dos monopólios dos Estados Unidos e que são prejudicados por estes.

São forças, portanto, extremamente heterogêneas pelo seu caráter de classe. Incluem desde o proletariado, que tem interesse nas mais profundas transformações revolucionárias, até parcelas das forças mais conservadoras da sociedade brasileira. A sua consequência na luta contra o imperialismo norte-americano não pode ser evidentemente a mesma, porém todas essas forças possuem motivos para se unirem contra a política de submissão ao imperialismo norte-americano. Quanto mais ampla for esta unidade, maiores serão as possibilidades de infligir uma derrota completa àquela política e garantir um curso independente, progressista e democrático ao desenvolvimento da nação brasileira.

\section{V - A frente única e a luta por um governo nacionalista e democrático}

As tarefas impostas pela necessidade do desenvolvimento independente e progressista do país não podem ser resolvidas por nenhuma força social isoladamente. Disto decorre a exigência objetiva aliança entre todas as forças interessadas na luta contra a política de submissão ao imperialismo norte-americano. A experiência da vida política brasileira tem demonstrado que as vitórias anti-imperialistas e democráticas só puderam ser obtidas pela atuação em frente única daquelas forças. 
A frente única se manifesta nas múltiplas formas concretas de atuação ou de organização em comum, que surgem no país, por iniciativas de diferentes origens e de acordo com as exigências da situação. Entre estas formas, a mais importante atualmente é o movimento nacionalista. O seu desenvolvimento expressa um grau mais elevado de unidade e concentração das forças anti-imperialistas. Constituiu um fato novo, resultante não só de fatores objetivos, entre os quais o desenvolvimento do capitalismo, que fortaleceu as posições da burguesia, como também das lutas patrióticas de massas, que se travaram durante muitos anos com a participação combativa do proletariado e de sua vanguarda comunista. Tendem a unir-se e podem efetivamente unir-se no movimento nacionalista a classe operária, os camponeses, a pequena burguesia urbana, a burguesia e os setores de latifundiários que possuem contradições com o imperialismo norte-americano.

O movimento nacionalista vem exercendo influência para elevar a consciência anti-imperialista das massas e para agrupar os setores nacionalistas dos partidos políticos, do parlamento, das Forças Armadas e do próprio governo. Superando as divergências que existem entre os seus participantes, o movimento nacionalista atrai para a sua frente de luta entidades, partidos, correntes e personalidades do mais variado caráter social e orientação política. Assim é que a Frente Parlamentar Nacionalista, cujo aparecimento tem notável significação em nossa vida política, unificou a ação de grande número de parlamentares pertencentes aos mais diversos partidos com representação no Congresso, quer sejam governistas ou oposicionistas.

O movimento nacionalista vem surgindo nas diferentes regiões com plataformas que, ao lado de pontos comuns, apresentam questões variadas, de acordo com a influência de determinadas forças políticas e da maior sensibilidade, por motivos locais, a esta ou aquela reivindicação antiimperialista. Os comunistas consideram que é necessário tudo fazer, dentro do mais alto espírito de unidade, para impulsionar o movimento nacionalista, ampliar seu caráter de massas e ajudar sua coordenação em escala nacional. Isto contribuirá para acelerar a polarização em processo entre às forças anti-imperialistas e democráticas de um lado, e as forças entreguistas do outro lado.

Os comunistas devem ser um fator por excelência unitário dentro da frente única nacionalista e democrática. Por isto, não condicionam a sua permanência na frente única à total aceitação de suas opiniões. Os participantes da frente única poderão aceitar essas opiniões somente como resultado de sua justeza, de sua força persuasiva e, acima de tudo, da sua comprovação pela experiência política concreta. Defendendo firmemente suas opiniões, os comunistas consideram que, se forem justas, tais opiniões acabarão sendo aceitas pelas massas e pelos aliados, vindo a prevalecer através de processos democráticos, dentro da frente única. Os comunistas não são exclusivistas e, ao mesmo tempo que encaram com espírito autocrítico a sua própria atividade, aceitam e valorizam as opiniões corretas procedentes das outras forças da frente única.

Sendo inevitavelmente heterogênea, a frente única nacionalista e democrática encerra contradições. Por um lado, há interesses comuns e, portanto, há unidade. Este é um aspecto fundamental e explica a necessidade da existência da frente única, a sua capacidade de superar as contradições internas entre os seus componentes. Por outro lado, há interesses contraditórios e, portanto, as forças sociais integrantes da frente única se opõem no terreno de certas questões, esforçando-se para fazer prevalecer seus interesses e pontos de vista.

O proletariado e a burguesia se aliam em torno do objetivo comum de lutar por um desenvolvimento independente e progressista contra o imperialismo norte-americano. Embora explorado pela burguesia, é do interesse do proletariado aliar-se a ela, uma vez que sofre mais do atraso do país e da exploração imperialista do que do desenvolvimento capitalista. Entretanto, marchando unidos para atingir um objetivo comum, a burguesia e o proletariado possuem também interesses contraditórios.

A burguesia se empenha em recolher para si todos os frutos do desenvolvimento econômico do país, intensificando a exploração das massas trabalhadoras e lançando sobre elas o peso das dificuldades. Por isto, a burguesia é uma força revolucionária inconsequente, que vacila em certos momentos, tende aos compromissos com os setores entreguistas e teme a ação independente das massas.

$\mathrm{O}$ proletariado tem interesse no desenvolvimento anti-imperialista e democrático consequente. A fim de assegurá-lo, ao mesmo tempo que luta pela causa comum de todas as classes e camadas que se opõem à exploração imperialista norte-americana, o proletariado defende os seus interesses específicos e os das vastas massas trabalhadoras e bate-se por amplas liberdades democráticas, que facilitem a ação independente das massas. $\mathrm{O}$ 
proletariado deve salvaguardar, por isto, a sua independência ideológica, política e organizativa dentro da frente única.

É indispensável; entretanto, jamais perder de vista que a luta dentro da frente única é diferente, em princípio, da luta que a frente única trava contra o imperialismo norte-americano e as forças entreguistas. Neste último caso, o objetivo consiste em isolar o inimigo principal da nação brasileira e derrotar a sua política. Já a luta do proletariado dentro da frente única não tem por fïm isolar a burguesia nem romper a aliança com ela, mas visa a defender os interesses específicos do proletariado e das vastas massas, simultaneamente ganhando a própria burguesia e as demais forças para aumentar a coesão da frente única. Por se travar dentro da frente única, esta luta deve ser conduzida de modo adequado, através da crítica ou de outras formas, evitando elevar as contradições internas da frente única ao mesmo nível da contradição principal, que opõe a nação ao imperialismo norte-americano e seus agentes. Assim, é preciso ter sempre em vista que as contradições de interesses e divergências de opinião dentro da frente única, embora não devam ser ocultadas e venham a causar dificuldades, podem ser abordadas e superadas sem romper a unidade.

Os comunistas de modo algum condicionam a sua participação na frente única a uma prévia direção do movimento. Tendo por objetivo a ampliação e a coesão da frente única, os comunistas trabalham para que as forças anti-imperialistas e democráticas, principalmente as grandes massas da cidade e do campo, aceitem a direção do proletariado, uma vez que esta direção é, do ponto de vista histórico, a única capaz de dar à frente única firmeza e consequência política. A conquista da hegemonia do proletariado é, porém, um processo de luta árduo e paulatino, que avançará à medida em que a classe operária forjar a sua unidade, estabelecer laços de aliança com os camponeses e defender de modo acertado os interesses comuns de todas as forças que participam da frente única.

Para a unidade da classe operária, tem grande importância o fortalecimento do movimento sindical. Este alcançou numerosas vitórias nos últimos tempos, possibilitando aos trabalhadores defender o seu nível de vida, restabelecer a liberdade sindical e elevar o seu grau de unidade e organização. As organizações intersindicais têm contribuído para a unidade da classe operária, mas a experiência vem demonstrando que o movimento sindical tem avançado à medida que se fortalece a unidade de ação dos trabalhadores nos sindicatos, federações e confederações, isto é, nos quadros da organização sindical existente no país. O movimento sindical tem avançado igualmente à medida em que os trabalhadores aprendem a utilizar as conquistas da legislação social vigente e procuram concretizá-la e aperfeiçoá-la, influindo no Parlamento, com a pressão de massas, para a aprovação de novas leis. Os sindicatos e as demais organizações profissionais não devem servir a objetivos partidários, mas precisam ser instrumentos da unidade dos trabalhadores de todas as tendências ideológicas e políticas, na luta por suas reivindicações imediatas, pelo direito de greve, pelo melhoramento da previdência social, etc. Simultaneamente, cabe aos sindicatos um grande papel no amplo movimento nacionalista e democrático.

Os camponeses constituem a massa mais numerosa da nação e representam uma força cuja mobilização é indispensável ao desenvolvimento consequente das lutas do povo brasileiro. $\mathrm{O}$ movimento camponês se encontra, entretanto, bastante atrasado, sendo baixíssimo o seu nível de organização. Para impulsionar o movimento camponês, é preciso partir do seu nível atual, tomando por base as reivindicações mais imediatas e viáveis, como o salário mínimo, a baixa do arrendamento, a garantia contra os despejos e evitando, no trabalho prático, as palavras de ordem radicais que ainda não encontram condições maduras para a sua realização. Também no campo, a experiência demonstra que a atuação através de formas legais de luta e de organização é aquela que permite alcançar êxitos para as massas. Assim é que tem progredido, além das associações rurais e cooperativas, a organização dos assalariados e semiassalariados em sindicatos, que já obtiveram vitórias em contendas com fazendeiros. Tem grande importância a defesa jurídica dos direitos já assegurados aos camponeses. A ação de massas se mostra indispensável para vencer a resistência dos latifundiários no Parlamento e conquistar a aprovação de leis que correspondam aos interesses dos trabalhadores agrícolas, inclusive a elaboração de uma legislação trabalhista adequada ao campo.

As camadas médias urbanas são extremamente sensíveis às reivindicações de caráter nacionalista e democrático. Aos pequenos negociantes, ao funcionalismo civil e militar e a outros setores da pequena burguesia cabe um posto destacado nas lutas do povo brasileiro. Importante papel desempenha a intelectualidade, que em sua esmagadora maioria está interessada no progresso e na emancipação nacional. Como setor mais 
combativo da intelectualidade, o movimento estudantil tem dado importante contribuição às lutas do povo brasileiro.

A unidade dos estudantes das mais diversas tendências doutrinárias e políticas é um fator essencial para o fortalecimento das organizações estudantis, universitárias e secundárias, que têm sido baluartes da frente única nacionalista e democrática. Seguindo o exemplo dos estudantes, a juventude dos sindicatos, dos clubes esportivos e recreativos pode unir-se e obter vitórias na luta por suas reivindicações.

A formulação dos objetivos comuns, num processo de discussão democrática, vai-se tomando necessária para a frente única à medida que aumenta a envergadura de suas tarefas. Os comunistas são de opinião que uma plataforma de frente única deve incluir os seguintes pontos fundamentais:

$\left(1^{\circ}\right)$ Política exterior independente e de paz. Estabelecimento de relações amistosas com todos os países, acima de diferenças de regime social, na base de respeito mútuo da integridade territorial e da soberania, da não agressão, da não intervenção nos assuntos internos e da igualdade de direitos e vantagens recíprocas. Desvinculação de compromissos com quaisquer blocos militares, denúncia de tratados belicistas e de ajustes antinacionais como o da cessão de Fernando de Noronha. Apoio às propostas que visem ao alívio da tensão internacional e ao término da "guerra fria". Apoio às lutas de libertação nacional de todos os povos.

$\left(2^{\circ}\right)$ Desenvolvimento independente e progressista da economia nacional. Intercâmbio comercial com todos os países, inclusive socialistas. Desenvolvimento da iniciativa estatal nacionalista nos setores do petróleo, energia elétrica, siderurgia, minerais estratégicos e outros setores básicos. Proteção e estímulo da iniciativa privada nacional. Execução de um programa federal para o desenvolvimento das regiões mais atrasadas do país e, em particular, incentivo à industrialização do nordeste. Revogação dos privilégios cambiais ou de qualquer outra ordem concedidos ao capital estrangeiro, selecionando suas inversões de acordo com os interesses do desenvolvimento do país e sem prejuízo dos empreendimentos nacionais. Dar preferência aos financiamentos em geral, governamentais ou não, sempre que não condicionados a exigências políticas e escolhendo livremente aqueles que, seja qual for sua procedência, ofereçam melhores condições no que se refere a juros, prazos de amortização e assistência técnica. $\left(3^{\circ}\right)$ Medidas de reforma agrária em favor das massas camponesas. Redução das taxas de arrendamento e prolongamento dos seus prazos contratuais. Defesa dos camponeses contra a grilagem e os despejos. Facilitar aos camponeses o acesso à terra, particularmente junto aos centros urbanos e vias de comunicação. Garantia da posse da terra e entrega de títulos de propriedade aos atuais posseiros. Aplicação dos direitos dos trabalhadores do campo já consolidados em lei. Legislação trabalhista adequada ao campo. Facilitar aos camponeses o crédito bancário, particularmente do Banco do Brasil, os transportes, a armazenagem e a assistência técnica.

$\left(4^{\circ}\right)$ Elevação do nível de vida do povo. Combate enérgico à inflação e à carestia. Equilíbrio orçamentário e política tributária que não sacrifique as massas nem prejudique as atividades produtivas. Salários e vencimentos que assegurem melhores condições de vida aos trabalhadores e ao funcionalismo. Democratização dos órgãos governamentais de controle do abastecimento e dos preços, de tal maneira que possam servir efetivamente aos interesses das massas populares. Aumento das verbas destinadas à educação e saúde do povo. Estímulo ao desenvolvimento da cultura nacional. Aplicação efetiva e melhoria da legislação trabalhista.

$\left(5^{\circ}\right)$ Consolidação e ampliação da legalidade democrática. Garantia dos direitos democráticos contidos na Constituição. Abolição completa das discriminações políticas e ideológicas. Garantia do direito de greve e dos direitos sindicais dos trabalhadores. Direito de voto aos analfabetos, bem como aos soldados e marinheiros.

Os comunistas apresentam esta plataforma para um amplo debate do qual possa resultar a formulação unitária dos objetivos comuns das forças nacionalistas e democráticas.

A frente única nacionalista e democrática acumula forças à medida que luta por soluções positivas para os problemas colocados na ordem do dia, realizando-as na proporção de sua capacidade e das condições favoráveis de cada momento. A exigência dessas soluções positivas para os problemas brasileiros conduz, inevitavelmente, à necessidade de um governo que possa aplicar com firmeza em todas as esferas da política interna e exterior a política de desenvolvimento e de emancipação reclamada pelo povo brasileiro. A luta das correntes nacionalistas e democráticas para alcançar modificações na composição e na política do 
governo atual assume, e tende a assumir cada vez mais, o caráter de luta por um governo de coligação nacionalista e democrática.

Um governo nacionalista e democrático pode ser conquistado pela frente única nos quadros do regime vigente e aplicar uma política externa de independência e de paz, assegurar o desenvolvimento independente e progressista da economia nacional, tomar medidas em favor do bem-estar das massas, garantir as liberdades democráticas.

O desenvolvimento da situação no país indica que esta orientação política pode vir a ser gradualmente realizada por um ou por sucessivos governos que se apoiem na frente única nacionalista e democrática.

Um governo nacionalista e democrático dependerá fundamentalmente, do apoio das massas e, por isto, o ascenso do movimento de massas não poderá deixar de influir no sentido da radicalização de sua composição e de sua política. Esta radicalização será também resultado da necessidade inevitável de medidas mais enérgicas e profundas diante dos atentados do imperialismo norte-americano e das forças entreguistas e reacionárias no país.

O curso dos acontecimentos no Brasil indica, por conseguinte, a possibilidade real de um processo em que, sob a pressão das ações independentes das massas e diante da necessidade de medidas mais consequentes contra o inimigo, principal da nação, um governo de coligação nacionalista e democrática abrirá caminho para uma nova correlação de forças, que possibilite completar as transformações revolucionárias exigidas pelo desenvolvimento econômico e social de nossa Pátria.

Ainda que dispostos a participar dos governos de caráter nacionalista e democrático, os comunistas os apoiarão de modo resoluto, mesmo que não venham a fazer parte de sua composição.

\section{VI - O caminho pacífico da revolução brasileira}

Os comunistas consideram que existe hoje em nosso país a possibilidade real de conduzir, por formas e meios pacíficos, a revolução anti-imperialista e antifeudal. Nestas condições, este caminho é o que convém à classe operária e a toda a nação. Como representantes da classe operária e patriotas, os comunistas, tanto quanto deles dependa, tudo farão para transformar aquela possibilidade em realidade.

O caminho pacífico da revolução brasileira é possível em virtude de fatores como a democratização crescente da vida política, o ascenso do movimento operário e o desenvolvimento da frente única nacionalista e democrática em nosso país. Sua possibilidade se tornou real em virtude das mudanças qualitativas da situação internacional, que resultaram numa correlação de forcas decididamente favorável à classe operária e ao movimento de libertação dos povos.

O caminho pacífico significa a atuação de todas as correntes antiimperialistas dentro da legalidade democrática e constitucional, com a utilização de formas legais de luta e de organização de massas. É necessário, pois, defender esta legalidade e estendê-la, em benefício das massas. $\mathrm{O}$ aperfeiçoamento da legalidade, através de reformas democráticas da Constituição, deve e pode ser alcançado pacificamente, combinando a ação parlamentar e a extraparlamentar.

O povo brasileiro pode resolver pacificamente os seus problemas básicos com a acumulação, gradual mas incessante, de reformas profundas e consequentes na estrutura econômica e nas instituições políticas, chegando-se até à realização completa das transformações radicais colocadas na ordem do dia pelo próprio desenvolvimento econômico e social da nação.

A fïm de encaminhar a solução de seus problemas vitais, o povo brasileiro necessita conquistar um governo nacionalista e democrático. Esta conquista poderá ser efetuada através dos seguintes meios mais prováveis:

1. Pela pressão pacífica das massas populares e de todas as correntes nacionalistas, dentro e fora do Parlamento, no sentido de fortalecer e ampliar o setor nacionalista do atual governo, com o afastamento do poder de todos os entreguistas e sua substituição por elementos nacionalistas.

2. Através da vitória da frente única nacionalista e democrática nos pleitos eleitorais.

3. Pela resistência das massas populares, unidas aos setores nacionalistas do Parlamento, das forças armadas e do governo, para impor ou restabelecer a legalidade democrática, no caso de tentativas de golpe por 
parte dos entreguistas e reacionários, que se proponham implantar no país uma ditadura a serviço dos monopólios norte-americanos.

O complexo desenvolvimento da vida política nacional é que determinará como será realizada a conquista de um governo nacionalista e democrático.

Sejam quais forem as vicissitudes que o povo brasileiro tiver de enfrentar para resolver pacificamente os seus problemas, será sempre necessário o amplo desenvolvimento da luta de classes do proletariado, dos camponeses e das camadas médias urbanas em defesa dos seus interesses específicos e dos interesses gerais da nação.

A escolha das formas e meios para transformar a sociedade brasileira não depende somente do proletariado e das demais forças patrióticas. No caso em que os inimigos do povo brasileiro venham a empregar a violência contra as forças progressistas da nação, é indispensável ter em vista outra possibilidade a de uma solução não pacífica. Os sofrimentos que recaírem sobre as massas, em tal caso, serão da inteira responsabilidade dos inimigos do povo brasileiro.

Quanto aos comunistas, tudo farão para alcançar os objetivos vitais do proletariado e do povo por um caminho que, sendo de luta árdua, de contradições e de choques, pode evitar o derramamento de sangue na insurreição armada ou na guerra civil. Os comunistas confiam em que, nas circunstâncias favoráveis da situação internacional, as forças antiimperialistas e democráticas terão condições para garantir o curso pacífico da revolução brasileira.

\section{VII - Pela vitória da frente única nacionalista e democrática nas eleições}

A experiência política do país vem demonstrando que o povo já alcançou importantes vitórias dentro do Parlamento e dos órgãos legislativos nos Estados e municípios. Esta experiência também já demonstrou que é possível eleger nacionalistas e democratas para os postos executivos. As eleições constituem, portanto, um acontecimento de excepcional importância em nossa vida política.
As eleições, no Brasil, ainda estão submetidas a sérias restrições antidemocráticas. Certas destas restrições derivam do poder econômico e político concentrado em massas das classes exploradoras e são inevitáveis mesmo nas melhores condições da democracia burguesa. Outras, porém, são restrições possíveis de eliminar ainda no regime atual, à medida que avança o processo de democratização. Os comunistas lutam, por isto, pela extensão do direito de voto aos analfabetos, bem como aos soldados e marinheiros. Lutam, igualmente, pela restituição da legalidade ao Partido Comunista, fazendo cessar uma discriminação anticonstitucional consumada numa conjuntura reacionária e mantida até hoje em flagrante desrespeito aos postulados da Carta Magna.

As restrições antidemocráticas que ainda pesam sobre o processo eleitoral não impedem, porém, a afirmação da sua crescente importância para determinar os rumos da vida política do país. Combinadas a outras formas pacíficas e legais de lutas de massas, as eleições podem dar vitórias decisivas ao povo. Massas de milhões vêm utilizando o voto para expressar a sua vontade e influir nos destinos da nação. A participação mais entusiástica nas eleições é, assim, um dever para os comunistas.

Esta participação não visa exclusivamente a obter pequenos proveitos imediatos e a utilizar uma oportunidade para fazer agitação de palavras de ordem. O objetivo fundamental da participação dos comunistas nas eleições consiste em eleger para os postos executivos e legislativos os candidatos da frente única, que possam fortalecer os setores nacionalistas do Parlamento e do governo. Todo o trabalho eleitoral dos comunistas, seja em âmbito nacional como em estadual e municipal, deve ser considerado uma parte do trabalho geral de formação e desenvolvimento da frente única, visando sempre à mudança da correlação de forças políticas e à conquista de um governo nacionalista e democrático.

Os comunistas se empenham, por este motivo, em contribuir para a constituição de amplas coligações eleitorais, que tenham força para levar à vitória os candidatos da frente única. A ação independente dos comunistas se realizará, não fora, mas dentro da frente única. Lutando, na medida de suas possibilidades, para eleger seus próprios candidatos, os comunistas não adotam, porém, uma posição exclusivista, colocam acima de tudo a necessidade de desenvolver e fortalecer a frente única e consideram que a vitória de candidatos não comunistas da frente única é também sua vitória. 
Esta orientação contribuirá para aprofundar nacionalmente e em cada local a polarizado em processo entre nacionalistas e entreguistas, a fim de isolar e derrotar os candidatos comprometidos com o imperialismo norte-americano.

Buscando formar amplas coligações eleitorais, que levem à vitória os nacionalistas e os democratas, é necessário ter em vista a composição de classe mais ou menos heterogênea dos partidos políticos brasileiros, sem, entretanto, estabelecer identidade entre eles. Os comunistas apoiam os elementos nacionalistas e democratas que existem em todos os Partidos. Tais elementos constituem uma ala considerável do PSD, a qual tem lutado com relativo êxito contra a ala reacionária do mesmo partido, ligada aos latifundiários mais retrógrados e a interesses imperialistas. Em proporção menor, existem elementos nacionalistas na UDN que se chocam com a alta direção nacional do seu partido, ainda dominada por conhecidos golpistas e porta-vozes do imperialismo norte-americano. Partidos como o PTB, o PSP e o PSB, que possuem maior base popular nos centros urbanos, apresentam uma tendência nacionalista e democrática mais acentuada. O PTB, cujo maior contingente eleitoral provém das massas trabalhadoras, de modo geral orienta-se por uma política nacionalista e popular. $\mathrm{O}$ mesmo ocorre com o PSB, cuja base social repousa em setores da pequena burguesia urbana e, em particular, da intelectualidade. Tanto o PTB como o PSB já defendem plataformas nacionalistas e democráticas.

À medida que se desenvolve o capitalismo no país, os partidos políticos brasileiros adquirem um caráter cada vez mais estável e nacional. Em virtude, porém, da extrema desigualdade de desenvolvimento que se verifica entre as diferentes regiões, os partidos políticos não puderam ainda superar as divergências, por vezes agudas, que lavram entre as suas seções estaduais e até mesmo municipais. Esta circunstância não pode deixar de ser levada em conta, a fim de distinguir, com justeza, as variações de orientação entre os diretórios nacionais, estaduais e municipais.

Os comunistas apoiam nas eleições os partidos, alas e seções de partidos e personalidades de atuação nacionalista reconhecida, não confundindo-os, porém, com os falsos nacionalistas, que procuram enganar o povo com a sua demagogia eleitoreira.

É com esta visão das eleições e de suas perspectivas essenciais que os comunistas se mobilizam para tomar parte nos pleitos de 1958 e 1960.

\section{VIII - Fortalecer o Partido para a aplicação de uma nova política}

O proletariado brasileiro necessita de uma vanguarda marxistaleninista organizada e combativa a fria de realizar sua política de classe.

O Partido Comunista Brasileiro, que é esta vanguarda, deve ser capaz de cumprir o seu papel na ação política concreta.

Isto exige que o nosso Partido se depure de persistentes defeitos e adquira qualidades novas. O subjetivismo, que exerceu longo domínio em nossas fronteiras, deve ser combatido em profundidade, através da reeducação dos dirigentes e militantes no espírito de uma nova política, que emane diretamente das condições objetivas de nosso país e seja a correta aplicação dos princípios universais do marxismo-leninismo às originais particularidades concretas do desenvolvimento histórico nacional. O abandono dos princípios universais do marxismo-leninismo, como síntese científica da experiência do movimento operário mundial, conduz inevitavelmente à desfiguração do caráter de classe do Partido, e à degenerescência revisionista. Mas o desconhecimento das particularidades concretas do próprio país condena o Partido, irremediavelmente, à impotência sectária e dogmática.

As concepções dogmáticas e sectárias, que nas condições atuais de nosso Partido constituem o perigo fundamental a combater, se opõem de modo radical ao próprio caráter da missão que os comunistas têm a cumprir. A frente da classe operária deve estar um Partido que saiba dirigir a luta pelos objetivos revolucionários na ação política corrente, diária, determinada pelas próprias exigências do movimento real das massas, das classes e das forças políticas. A esta característica essencial se subordinam as atividades de agitação e propaganda, do trabalho de massas e de organização do Partido.

Para que os comunistas possam cumprir sua importante tarefa, devem estar a serviço das massas e lançar-se decididamente à atividade junto às massas. Ao invés de se voltarem apenas para o trabalho interno do Partido, precisam dedicar o fundamental de suas energias à atuação legal nas organizações de massas e aí exercer uma função eminentemente construtiva. É indispensável, por conseguinte, tomar as medidas adequadas para que o maior número possível de quadros, militantes e dirigentes, realizem atividades legais entre as massas. Participando das lutas de massas 
nos movimentos reivindicativos, nas campanhas políticas, nas eleições, os comunistas não tem outro fim senão o de tornar vitoriosas as aspirações das massas, aprender com elas e educá-las a partir do nível de consciência que já atingiram. Os comunistas devem ser em toda parte trabalhadores isentos de exclusivismo, abnegados e consequentes, pela construção da frente única nacionalista e democrática.

O Comitê Central concita a todos os militantes a empenharem-se no fortalecimento do Partido para torná-lo o instrumento adequado à execução vitoriosa da nova política traçada nesta Declaração, que deve guiar, de agora em diante, toda a atividade do Partido.

O Comitê Central do PCB

Março de 1958 